\title{
Impact and Adoption of Proprietary Seed Technologies in Developing Countries
}

\author{
Dissertation submitted for \\ the degree of Doctor of Philosophy in the \\ International Ph.D. Program for Agricultural Sciences in Göttingen (IPAG), \\ Faculty of Agricultural Sciences, \\ Georg-August-University Göttingen, Germany \\ by \\ Jonas Kathage \\ born in Bergisch Gladbach
}

Göttingen, December 2012 

1. Name of supervisor: Prof. Dr. Matin Qaim

2. Name of co-supervisor: Jun.-Prof. Dr. Meike Wollni

Date of dissertation: 14 February 2013 



\section{Summary}

In the 1980s, many developing countries began to liberalize their seed markets. This has led to an increased prevalence of proprietary seed technologies, including genetically modified (GM) crops. The implications for smallholder farmers are the subject of a controversial debate. Critics argue that privatization reduces the quality and affordability of seed for smallholder farmers. Proponents claim that proprietary seed technologies can raise agricultural productivity and incomes. In this dissertation we examine the impacts of proprietary seeds on smallholder farmers, with Bacillus thuringiensis (Bt) cotton in India and hybrid maize in Tanzania serving as two relevant cases. The third focus of this study relates to the adoption of proprietary seed technologies, again taking the case of hybrid maize in Tanzania.

As a result of foreign investment, an Indian seed firm transferred the Bt technology into a small number of cotton hybrids in the mid-1990s. These hybrids were approved for cultivation in 2002. Over the ensuing decade, multiple other seed firms incorporated the Bt technology into their own breeding programs. By 2011 about 90\% of the Indian cotton acreage was under Bt, grown by 7 million farmers. Bt cotton is resistant to bollworm, an important insect pest. Bt can thus reduce the need for chemical insecticides, and also increase effective yield. This would reduce pesticide cost and increase revenue, which might lead to higher farm income. But if Bt seed prices are high and productivity effects low, the income effect could be small or even negative.

Many impact studies of Bt have been published, but selection bias, impact dynamics and possible consequences beyond the plot level were not sufficiently taken into account. Here, we analyze panel data covering the years 2002-2008. Using panel models with farm and household fixed effects, we control for selection bias and look at the impact dynamics over time. We estimate that Bt increased yield by $24 \%$ and profit by $50 \%$ in $2002-2008$, and household living standard by $18 \%$ in 2006-2008. Furthermore, there are indications that yield 
and profit effects of Bt increased over time. We also observe that insecticide use on Bt and conventional plots decreased over time, probably a sign of large-scale suppression of bollworm populations by Bt.

In Tanzania, seed market liberalization has attracted several private seed firms since the early 1990s that have been selling hybrid maize. Hybrids can confer a yield advantage over nonhybrids, raising revenue and farm income. On the other hand, if hybrid seeds are more expensive than nonhybrid seeds, the income effect might not be positive. In addition, a nonhybrid with superior germplasm could even achieve higher yield than some hybrids.

While there are studies that evaluate the impact of hybrid maize on farm productivity in Africa, they usually do not control for potentially confounding factors, such as soil quality or fertilizer use. Moreover, hardly any study on modern maize varieties in Africa has looked beyond farm productivity to analyze impacts on household living standard. Analyzing crosssectional household survey data collected in the north and east of Tanzania, we find that hybrids raise yield by $50-60 \%$. As a result, hybrid adopters realize higher profits. The benefits mostly occur in the north, where hybrids also increase household living standard by $15 \%$. In the east, hybrids confer no gain in yield, profit or living standard. But since the vast majority of hybrid adopters are located in the north, most adopters benefit from hybrids. We also find that the yield impact of hybrids is not dependent on the use of fertilizer, irrigation, pesticides, or intercropping.

The adoption rate of hybrid maize in Tanzania is low and one possible reason is that nonadopters are constrained, for example by lack of information about hybrids. In our sample, $31 \%$ of farmers adopt hybrids. In the north, most farmers are aware of hybrids and $49 \%$ are adopters. In the east, only 50\% are aware and 12\% adopters of hybrids. Using the average treatment effect framework, we find that closure of the exposure gap would raise the overall adoption rate to $45 \%$. However, the majority of new adopters would be in the east, where hybrids have a negligible impact on yield and profit. In the north, where the benefits of hybrid 
adoption are more significant, most farmers are already aware of hybrids. We also observe that information about hybrids spreads through extension and farmer networks in the north but not in the east. Aside from the information factor, we find no evidence for constraints related to risk or credit. Therefore it is likely that adoption and awareness of hybrids are primarily driven by the benefits hybrids offer relative to nonhybrids.

We conclude that the private sector can deliver improved seed technologies to smallholder farmers in developing countries, and that improved seed technologies, including GM crops, can benefit these farmers. Accordingly, liberalization of seed markets should be promoted in developing countries. Second, regulations that impede the availability of seed technologies must consider the potential benefits these technologies offer to farmers. Finally, policymakers and donors must weigh alleviating adoption constraints against technology improvements in their funding decisions. 


\section{Zusammenfassung}

In den 1980er Jahren begannen viele Entwicklungsländer, ihre Saatgutmärkte zu liberalisieren. In der Folge verbreitete sich die Nutzung proprietärer Saatguttechnologien, einschließlich gentechnisch veränderter Pflanzen (GV-Pflanzen). Die Konsequenzen dieser Entwicklung für Kleinbauern werden seither kontrovers diskutiert. Kritiker befürchten, dass Privatisierung die Qualität von Saatgut sowie den kleinbäuerlichen Zugang zu ihm verschlechtert. Befürworter gehen davon aus, dass proprietäres Saatgut landwirtschaftliche Produktivität und Einkommen steigern kann. In dieser Dissertation untersuchen wir Auswirkungen proprietärer Saatguttechnologien auf Kleinbauern. Bacillus thuringiensis-Baumwolle (Bt-Baumwolle) in Indien und Hybridmais in Tansania. Der dritte Fokus dieser Arbeit liegt auf der Adoption proprietärer Saatguttechnologien, wo erneut auf Hybridmais in Tansania Bezug genommen wird.

Infolge einer ausländischen Investition transferierte eine indische Saatgutfirma Mitte der 1990er Jahre die Bt-Technologie in mehrere Baumwollhybriden. Diese Hybriden wurden 2002 zum Anbau zugelassen. In den Folgejahren verwendeten auch zahlreiche andere Saatgutfirmen die Bt-Technologie in ihren Züchtungsprogrammen. 2011 bauten 7 Millionen Bauern auf etwa 90\% der indischen Baumwollfläche Bt-Baumwolle an. Sie ist gegen Kapselbohrer, eine Gruppe wichtiger Schädlingsinsekten, resistent. Dadurch kann sie den Einsatz von Insektiziden verringern und außerdem den effektiven Ertrag erhöhen. Dies würde Kosteneinsparungen bei Pestiziden und höhere Erlöse nach sich ziehen, welche wiederum das landwirtschaftliche Einkommen steigern können. Wenn aber die Saatgutpreise von Bt-Baumwolle hoch und die Ertragseffekte klein sind, könnte der Einkommenseffekt gering oder negativ ausfallen.

Zu den Auswirkungen von Bt-Baumwolle wurden viele Studien publiziert, aber Selektionsverzerrungen, die Entwicklungsdynamik der Effekte und über Einzelfelder hinausgehende Wirkungen wurden bisher nicht ausreichend berücksichtigt. Hier analysieren wir Panelda- 
ten aus dem Zeitraum 2002-2008. Mithilfe von Fixed-Effects-Modellen reduzieren wir Selektionsverzerrungen und betrachten den zeitlichen Verlauf der Effekte. Unsere Schätzergebnisse zeigen, dass Bt im Zeitraum 2002-2008 den Ertrag um 24\% und den Deckungsbeitrag um 50\% erhöhte, sowie den Lebensstandard im Zeitraum 2006-2008 um 18\%. Außerdem finden wir Hinweise für eine Steigerung der Ertrag- und Deckungsbeitragseffekte über den gesamten Zeitraum. Einen Rückgang des Insektizideinsatzes in Bt- und konventionellen Feldern, der wahrscheinlich ein Zeichen für eine starke Dezimierung von Kapselbohrern durch die Zunahme des Bt-Anbaus ist, können wir ebenfalls beobachten.

Nach der Liberalisierung des Saatgutmarkts in Tansania Anfang der 1990er Jahre begannen mehrere private Saatgutfirmen mit dem Vertrieb von Hybridmais. Hybriden können zu einem Ertragszuwachs führen, der wiederum Erlös und Einkommen steigern kann. Auf der anderen Seite könnte der Einkommenseffekt negativ ausfallen, wenn Hybridsaatgut teurer als Nichthybridsaatgut ist. Zudem kann ein leistungsstarker Nichthybride durchaus auch einen höheren Ertrag erzielen als mancher Hybride.

Es gibt zwar Studien, die Produktivitätseffekte von Hybridmais in Afrika evaluieren, aber in der Regel kontrollieren sie nicht Störfaktoren, wie etwa Bodenqualität oder Düngereinsatz. Darüber hinaus liegen kaum Untersuchungen zu modernen Maissorten in Afrika vor, die neben der Produktivität auch Effekte auf den Lebensstandard landwirtschaftlicher Haushalte berücksichtigen. Wir analysieren einen Querschnittsdatensatz aus dem Norden und Osten des Landes und finden einen Ertragszuwachs von 50-60\% durch Hybriden. Dieser führt auch zu einem höheren Deckungsbeitrag. Die Zugewinne treten vor allem im Norden auf, wo sie außerdem den Lebensstandard um 15\% erhöhen. Im Osten bringen Hybriden keine Vorteile hinsichtlich Ertrag, Deckungsbeitrag oder Lebensstandard. Da sich jedoch die Mehrheit der Anwender im Norden befindet, profitieren in einer überregionalen Betrachtung die meisten Hybridnutzer von der Technologie. Außerdem finden wir heraus, dass der Ertragseffekt von 
Hybriden unabhängig vom Einsatz von Mineraldünger, Bewässerung, Pestiziden oder Mischanbau ist.

Allerdings ist die Adoptionsrate von Hybridmais in Tansania gering. Ein möglicher Grund könnte darin liegen, dass seine Verwendung durch bestimmte Faktoren, wie etwa einen mangelnden Informationstand der Bauern bezüglich der Hybriden, erschwert ist. In unserer Stichprobe bauen 31\% der Bauern Hybridmais an. Im Norden sind Hybriden den meisten Bauern bekannt und 49\% verwenden die Technologie, während im Osten nur 50\% von der Technologie gehört haben und nur 12\% sie nutzen. Mithilfe des Average Treatment Effect Framework errechnen wir, dass eine Informierung aller Bauern über Hybriden die Adoptionsrate auf 45\% ansteigen lassen würde. Jedoch wären dann die meisten neuen Anwender im Osten, wo die Ertrags- und Deckungsbeitragseffekte von Hybriden klein sind. Im Norden, wo die Adoption einträglicher ist, haben bereits fast alle Bauern von Hybriden gehört. Außerdem zeigt sich, dass eine Verbreitung von Informationen über Hybriden durch Beratung und ländliche Netzwerke im Norden (nicht im Osten) stattfindet und daher als Resultat der dort höheren Nützlichkeit verstanden werden kann. Für diese Interpretation spricht auch, dass wir keine Hinweise finden, dass Risiko oder Mangel an Kreditzugang die Adoption verhindern. Daher erscheint es wahrscheinlich, dass Informationsflüsse und Adoptionsentscheidungen primär vom Nutzen, den Hybriden gegenüber Nichthybriden bieten, bestimmt werden.

Wir kommen zu dem Schluss, dass der Privatsektor verbesserte Saatguttechnologien für Kleinbauern in Entwicklungsländern liefern kann und dass derartige Saatguttechnologien einschließlich GV-Pflanzen diesen Kleinbauern dienlich sein können. Daher sollte die Liberalisierung von Saatgutmärkten in Entwicklungsländern unterstützt werden. Außerdem müssen Regulierungen, welche die Verfügbarkeit von Saatguttechnologien einschränken, den möglichen Nutzen dieser Technologien für Landwirte berücksichtigen. Und schließlich sollten Politik und Geberorganisationen in ihren Förderentscheidungen die Beseitigung von Adoptionshemmnissen gegen die Schaffung verbesserter Technologien abwägen. 


\section{Acknowledgements}

Many people made this dissertation possible. First, Prof. Dr. Matin Qaim, my supervisor at the Department of Agricultural Economics and Rural Development at the University of Göttingen, deserves my gratitude. His encouragement and support of this project were very valuable to me. I am especially grateful for the thorough feedback he frequently provided on my work.

I would like to thank Jun.-Prof. Dr. Meike Wollni for co-supervising this dissertation as well as Prof. Dr. Bernhard Brümmer for serving on the examination committee.

I am indebted to the numerous researchers and assistants who were involved in assembling the Indian panel data set and the German Research Foundation (DFG) for funding this long-term research project.

The contribution of various people involved with the Tanzanian research is appreciated. I thank Menale Kassie and Bekele Shiferaw at the International Maize and Wheat Improvement Center (CIMMYT) for supervising the data collection and analysis. My gratitude also goes to Geoffrey Muricho, without whom the survey would have been much more difficult. The data collection in Tanzania was made possible only by the cooperators and enumerators from Selian Agricultural Research Institute (SARI) at Arusha and Ilonga Agricultural Research Institute (ARI-Ilonga), and the funding from the Australian Centre for International Agricultural Research (ACIAR).

I wish to acknowledge the Heinz Lohmann Foundation which provided funding for part of my doctoral studies.

I would like to mention Prof. William A. Masters, the greatest teacher I have encountered in my university studies. He encouraged me to pursue a doctoral degree in Agricultural Economics and has remained a source of inspiration while working on this dissertation. 
I thank my fellow doctoral students at the Chair of International Food Economics and Rural Development at the University of Göttingen for providing a friendly and stimulating research environment.

Finally, I am grateful to my girlfriend Anne and my family for their love and moral support. 


\section{Table of Contents}

Summary $\quad$ V

Zusammenfassung

$\begin{array}{ll}\text { Acknowledgements } & \text { XI }\end{array}$

Table of Contents $\quad$ XIII

$\begin{array}{ll}\text { List of Tables } & \text { XVI }\end{array}$

$\begin{array}{ll}\text { List of Figures } & \text { XVII }\end{array}$

$\begin{array}{ll}\text { Abbreviations } & \text { XVIII }\end{array}$

1 General Introduction $\quad 19$

$\begin{array}{llr}1.1 & \text { Background } & 19\end{array}$

1.1.1 Professionalization and Commercialization of Seed Markets 20

1.1.2 Seed Market Liberalization in India and Tanzania 22

$\begin{array}{lll}1.2 & \text { Problem Statement } & 23\end{array}$

1.2.1 Bt Cotton in India 24

1.2.2 Hybrid Maize in Tanzania 26

1.3 Research Objectives and Outline 28

2 Economic Impacts and Impact Dynamics of Bt Cotton in India 30

$\begin{array}{lll}2.1 & \text { Introduction } & 30\end{array}$

2.2 Results 32

2.2.1 Impact on Cotton Yield 34

2.2.2 Impact on Cotton Profit 36

2.2.3 Impact on Household Living Standard 37

$\begin{array}{lll}2.3 & \text { Discussion } & 38\end{array}$

2.4 Materials and Methods 39

$\begin{array}{lll}2.4 .1 & \text { Survey } & 39\end{array}$ 
2.4.2 Regression Models

3 Seed Market Liberalization, Hybrid Maize Adoption, and Impacts on

Smallholder Farmers in Tanzania

$\begin{array}{lll}3.1 & \text { Introduction } & 43\end{array}$

$\begin{array}{lll}3.2 & \text { Background } & 46\end{array}$

3.2.1 Seed Market Liberalization $\quad 46$

3.2.2 Seed Market Liberalization in Tanzania $\quad 47$

3.3 Data and Descriptive Statistics 49

$\begin{array}{lll}3.3 .1 & \text { Survey } & 49\end{array}$

3.3.2 Descriptive Analysis $\quad 49$

3.4 Econometric Approach 53

3.5 Regression Results and Discussion 56

3.5.1 Impact on Maize Yield 56

3.5.2 Impact on Household Living Standard 60

$\begin{array}{lll}3.6 & \text { Conclusion } & 62\end{array}$

4 Big Constraints or Small Returns? Explaining Nonadoption of 65 Hybrid Maize in Tanzania

$\begin{array}{lll}4.1 & \text { Introduction } & 65\end{array}$

$\begin{array}{lll}4.2 & \text { Background } & 67\end{array}$

$\begin{array}{lll}\text { 4.3 Analytical Framework } & 70\end{array}$

4.4 Data and Descriptive Statistics 73

$\begin{array}{lll}\text { 4.4.1 Survey } & 73\end{array}$

$\begin{array}{lll}\text { 4.4.2 Descriptive Statistics } & 73\end{array}$

$\begin{array}{lll}4.5 & \text { Results } & 77\end{array}$

$\begin{array}{lll}\text { 4.5.1 Determinants of Exposure and Adoption } & 77\end{array}$

4.5.2 Predicted Adoption Rates under Full Exposure 80 
$\begin{array}{lll}\text { 4.6 Conclusions } & 82\end{array}$

5 Conclusion $\quad 85$

5.1 Main Findings 85

$\begin{array}{llr}5.2 & \text { Policy Implications } & 88\end{array}$

5.3 Limitations and Possible Directions for Further Research 89

$\begin{array}{ll}\text { Bibliography } & 92\end{array}$

$\begin{array}{ll}\text { Appendix A. Additional Tables } & 104\end{array}$

Appendix B. Household Questionnaire (Tanzania) 110 


\section{List of Tables}

Table 2.1 Descriptive Statistics for 1,655 Plots and 533 Associated Households (Averages for 2002-2004 and 2006-2008)

Table 2.2 Net Impact of Bt on Cotton Yield and Profit per Acre

Table 2.3 Net Impact of Bt on Household Living Standard

Table 3.1 Maize Hybrids Released by the Private Sector, 1993-2007

Table 3.2 Descriptive Statistics at the Plot Level

Table 3.3 Descriptive Statistics at the Household Level

Table 3.4 Estimated Coefficients of the Yield Model

Table 3.5 Treatment Effects of Hybrid Adoption in Yield and Consumption Models with Different Proxies Added

Table 3.6 Estimated Coefficients of the Household Consumption Model

Table 4.1 Adoption Behavior, Impact, Causes, and Remedies

Table 4.2 Descriptive Statistics by Exposure Status 75

Table 4.3 Descriptive Statistics by Adoption Status among Exposed 76

Table 4.4 Determinants of Exposure and Exposure-corrected Adoption

Table 4.5 Determinants of Exposure and Exposure-corrected Adoption, by Region

Table 4.6 Predicted Adoption Rates

Table 4.7 Yield Impact of Hybrid Maize

Table A1 Descriptive Statistics for 1,655 Plots and 533 Associated Households (Averages for 2002-2004 and 2006-2008)

Table A2 Estimated Coefficients of Quadratic Production (Yield) Function

Table A3 Estimated Coefficients of Quadratic Profit Function 


\section{List of Figures}

Figure 3.1 Profit Analysis 


\section{Abbreviations}

\begin{tabular}{|c|c|}
\hline ATE & Average treatment effect \\
\hline $\mathrm{Bt}$ & Bacillus thuringiensis \\
\hline CI & Conditional independence \\
\hline CIMMYT & International Maize and Wheat Improvement Center \\
\hline FAOSTAT & Food and Agricultural Organization Statistical Database \\
\hline FOE & Friends of the Earth \\
\hline GAP & Adoption gap \\
\hline GM & Genetically modified \\
\hline GOI & Government of India \\
\hline GRAIN & Genetic Resources Action International \\
\hline GV & Gentechnisch verändert \\
\hline IMF & International Monetary Fund \\
\hline IPR & Intellectual property rights \\
\hline IV & Instrumental variable \\
\hline JEA & Joint exposure and adoption rate \\
\hline MMB & Mahyco-Monsanto Biotech \\
\hline MV & Modern variety \\
\hline NGO & Non-governmental organization \\
\hline OPV & Open-pollinated variety \\
\hline PSB & Population selection bias \\
\hline $\mathrm{R} \& \mathrm{D}$ & Research and development \\
\hline SOE & State-owned enterprise \\
\hline $\mathrm{TC}$ & Tissue culture \\
\hline UCS & Union of Concerned Scientists \\
\hline
\end{tabular}




\section{General Introduction}

\subsection{Background}

Agricultural productivity is an important engine of income growth and poverty reduction (Diao and Pratt, 2007; Dorward et al., 2004; Ruttan, 2001; Thirtle et al., 2003; Tiffin and Irz, 2006). Productivity growth in agriculture is more pro-poor than productivity growth elsewhere because most of the poor live in rural areas and derive their livelihoods directly or indirectly from agriculture (Minot et al., 2007).

Before the $20^{\text {th }}$ century, most increases in crop and animal production were based on growth in cultivated area. In the $21^{\text {st }}$ century, most gains are achieved through rising land productivity, marking the transition from a resource-based to a science-based system (Ruttan, 2001). In the agricultural development community, there is much debate about the optimal policy environment shaping this science-based system and in particular about the appropriate roles of the public and private actors in the seed sector (Dorward et al., 2004; Jayne et al., 2002; Kolady et al., 2012; Langyintuo et al., 2010; Matuschke and Qaim, 2008; Naseem et al., 2010; Pardey et al., 2012; Pingali and Traxler, 2002; Pray and Umali-Deininger, 1998; Tripp and Louwaars, 1997).

These discussions are taking place amid ongoing policy changes. Over the last decades, seed markets in many developing countries have witnessed a shift from public to private, involving removal of barriers to entry, privatization of former state monopolies, and strengthening of intellectual property rights (IPR). This raises the question whether farmers benefit from this changing environment or are worse off in terms of the quality of and the access to seed technologies, including genetically modified (GM) crops. In this dissertation 
we examine two cases of proprietary seed technologies: Bacillus thuringiensis (Bt) cotton in India and hybrid maize in Tanzania.

\subsubsection{Professionalization and Commercialization of Seed Markets}

Over millennia crops have evolved in response to natural and artificial selection. Farmers saved the seed from the best plants in their fields for propagation in the following season. With the advent of Mendelian genetics and other discoveries in biology in the early $20^{\text {th }}$ century, scientific plant breeding began to offer significant improvements over the traditional selection by farmers and sporadic experimenters. Higher-yielding hybrids, for instance, could be created by repeated selfing of cross-pollinated crops and then crossing the inbred lines. In the second half of the $20^{\text {th }}$ century, new scientific discoveries, particularly in molecular genetics, provided plant breeding with a whole new set of tools. For example, the targeted transfer of individual genes between unrelated organisms increased the range of possible crop characteristics and the efficiency at which they could be realized (Chahal and Gosal, 2002).

Scientific advances brought about new opportunities to outsource seed production. The first wave of commercial breeding and seed production was based on a technical use restriction. Hybrids lose much of their yield advantage when they are recycled. Therefore farmers have an incentive to use fresh hybrids in every season and source them from specialized seed producers. In the late 1920s, hybrid maize became the most important product of an emerging commercial seed sector in the US. Still, most crop improvements continued to be achieved via non-commercial routes. In many developing countries plant breeding also began to professionalize but remained in the province of the public sector for decades. For example, the high-yielding varieties of the Green Revolution were based on the non-commercial exchange of germplasm and were produced by scientists supported by public and philanthropic efforts, not by profit-oriented businesses (Kingsbury, 2009). 
Aside from hybrids, IPR became increasingly important drivers of private sector involvement. Over the course of the $20^{\text {th }}$ century IPR for crop varieties were strengthened and in the 1980s, the US extended the scope of protection to utility patents of biological materials. While there is no consensus among economists as to whether patents of this sort are generally desirable, patents have encouraged important innovations. The GM crops grown around the world since the mid-1990s can be seen as a consequence of the high level of IPR protection in the US biotechnology sector. However, the transfer of these technologies to developing countries was possible without these countries having to implement IPR comparable to the US. More important was the liberalization of their seed markets (Wright and Pardey, 2006).

The implications of the increasing role of private seed firms for farmers in developing countries are the subject of a controversial debate that extends beyond the research community. Critics argue that smallholder farmers fare better if they continue to recycle traditional seed instead of relying on purchased seed, which, in addition, could make farmers dependent on monopolistic seed suppliers (GRAIN, 2010a). In contrast, proponents of liberalization argue that the entry of private firms will lead to more competition, research and development (R\&D) investment, and transfer of technologies that can raise smallholder productivity and income (Pray et al., 2001). This debate is even more pronounced in the case of agricultural biotechnology. Opponents contend that GM technology further reduces choice and increases seed costs of farmers (Greenpeace, 2010), while proponents claim that it can be particularly useful to smallholders (Paarlberg, 2008).

The impacts of proprietary seed technologies on farmers in developing countries have also been approached in empirical research. Several studies show that farmers in developing countries can benefit from the adoption of proprietary seed technologies, including GM crops (Matuschke et al., 2007; Qaim et al., 2006). However, for some countries and technologies, existing evidence is scarce, inconsistent, or burdened with methodological problems (De Groote et al., 2005; Glover, 2010; Morris, 2002). Similarly, the study of adoption has yielded 
conflicting results (Duflo et al., 2008; Suri, 2011). These uncertainties have implications for appropriate policies surrounding seed markets and technology adoption. This dissertation contributes to the debate by filling some important gaps in the literature.

\subsubsection{Seed Market Liberalization in India and Tanzania}

In developing countries, seed market liberalization began in the 1980s. The move towards free markets was not restricted to the agricultural sector but part of major restructuring efforts, in many cases under the guidance of donor agencies including the International Monetary Fund and the World Bank ("Washington Consensus"). In Latin America this shift has been considerable, but less so in Asia and Africa where popular resistance to liberalization has been strong (Pray et al., 2001).

India started to restrict private seed firms in the late 1960s (Pray and Ramaswami, 1999). Entry of large firms, whether foreign or domestic, was impeded as well as private imports of seed for commercial or research purposes. This tight regulation lasted until the late 1980s. By 1991, several policy changes had radically altered the situation. Economy-wide, the industrial licensing system, which limited firm size, was abolished and the entry of foreign firms was facilitated. In the seed sector, the entry of large domestic as well as foreign firms was permitted, and private seed imports were no longer banned. A remarkable surge in $R \& D$ investments and in the number of private technology providers ensued (Pray et al., 2001). Several large firms entered the market which directly led to higher R\&D expenditures. In addition, incumbents reacted to these new entrants by boosting their own $R \& D$ investments. The resulting seed industry structure in 1995 was more competitive than in 1987. The most important products of the emerging private sector were hybrid sorghum, pearl millet, maize and cotton, as well as vegetable seeds.

While the spread of proprietary cotton hybrids was one result of liberalization, the most consequential new technology in the Indian seed market has been Bt cotton. Bt cotton 
contains one or more genes from the soil bacterium Bacillus thuringiensis. These genes produce toxins lethal to bollworms, which are important insect pests of cotton. Bt cotton was introduced in India by Monsanto, a US corporation, in a joint venture with the Indian firm Mahyco called Mahyco-Monsanto Biotech (MMB). Monsanto licensed its Bt event Bollgard I (containing the gene $c r y 1 A c$ ) to MMB, which released the first Bt cotton hybrids in 2002. Over the following years MMB sublicensed Bollgard I to dozens of Indian seed firms who transferred it into their own hybrids. In addition, more Bt events from other sources were deregulated, increasing competition not only in germplasm but also in Bt events (Murugkar et al., 2007).

The history of Tanzania's seed market policies is in important ways parallel to that of India. In the late 1960s, the socialist government initiated the nationalization of the major means of production. Over the next decades, private firms' involvement in the agricultural sector was severely restricted. Government-owned Tanzania Seed Company (Tanseed) was granted a legal monopoly on the production, importation and distribution of seed in 1973 (Minot et al., 2007). In the late 1980s, Tanzania enacted several reforms of its seed sector, including rapid privatization of parastatals. In the early 1990s private firms were for the first time allowed to enter the seed market. What ensued was an increase in the number of registered seed companies that focused mostly on hybrid maize.

\subsection{Problem Statement}

Seed market liberalization has led to the introduction of new proprietary seed technologies in developing countries. One main area of interest to researchers and policymakers is the economic impact these technologies have on farmers. This includes the study of adoption, i.e. to what extent and why the new technologies are used or not used. This dissertation focuses on the cases of Bt cotton in India and hybrid maize in Tanzania. The two cases differ considera- 
bly in the extent they have been investigated. Before more concrete research questions are formulated, an identification of knowledge gaps is in order.

\subsubsection{Bt Cotton in India}

The literature on the economic impact of Bt cotton in India is rather comprehensive. The reason is that India is not only a large country with millions of cotton farmers for whom the introduction of Bt could have significant implications. The question of impact has also been surrounded by great controversy in the public debate in India and abroad. In fact, there is no case of a GM crop technology in any country which has attracted more peer-reviewed empirical studies (Areal et al., 2013). Nevertheless, crucial gaps remain in the literature, which form the motivation for our study.

From a theoretical perspective, Bt could have several effects on cotton cultivation. The main difference to conventional cotton is that Bt cotton is resistant to several important pests collectively known as bollworms. The conventional way of dealing with bollworms, that millions of farmers have exhibited before the introduction of $\mathrm{Bt}$, was to spray chemical insecticides numerous times per season. In the 1990s, bollworm was such a damaging pest that about half of all Indian insecticides were applied to cotton (Choudhary and Laroia, 2001). Bt cotton can substitute for insecticides ${ }^{1}$ because it produces toxins that kill bollworms when they start feeding on the plant. However, Bt is not a perfect substitute for insecticides due to several reasons: First, insecticides have a larger target spectrum than Bt. Although bollworms are the most damaging pests, other pests such as aphids are not harmed by Bt. Therefore, Bt should

\footnotetext{
${ }^{1}$ The terms "insecticides“ and "pesticides“ are henceforth used to refer to chemicals or synthetics, even though in general Bt may also be called a (biological or microbial) insecticide. Furthermore, insecticide formulations containing Bt toxins extracted from Bt bacteria, which have been in agricultural use for decades and make up a majority of the global biological pesticide market, are referred to as "Bt products" in this dissertation. The use of $\mathrm{Bt}$ is here reserved to relate to Bt crops in general and Bt cotton in particular, unless otherwise stated.
} 
not be expected to eliminate insecticide use. Second, Bt has advantages over insecticides in targeting bollworms. Feeding bollworms are permanently exposed to Bt toxins but insecticide use depends on well-timed and targeted applications that are only periodic. In addition, some pests may be resistant to insecticides that have long been in use. Therefore, Bt may increase effective yield. In sum, the economic impact of Bt will depend mainly on the price premium of Bt compared to conventional seeds, insecticide cost savings, and additional revenue and (labor) costs associated with higher yield. Cost savings and yield effects derive from pest pressure and germplasm quality of Bt hybrids. Thus, the actual impact is an empirical question that can only be answered by data.

The first assessments of Bt cotton impacts in India were based on field trials and found pesticide savings as well as large yield and profit gains (Qaim, 2003; Qaim and Zilberman, 2003). Later studies reported similar results for the first two official growing seasons in 2002 and 2003 (Bennett et al., 2005; Bennett et al., 2006; Qaim et al., 2006). These studies, which covered a total of five states in central and southern India, also discovered effects differing by farm size, irrigation, region, and hybrid germplasm. A village study observed that members of poor households with little or no land benefited from Bt mainly as hired workers on larger farms where Bt increased demand for harvest labor (Subramanian and Qaim, 2009, 2010). Other research showed that Bt reduced the incidence of pesticide poisonings among farmers (Kouser and Qaim, 2011). It was also found that the amount of pesticides sprayed on conventional cotton decreased over time, representing positive spillovers from Bt through the suppression of bollworm populations (Krishna and Qaim, 2012). Several meta-analyses and review articles, which also covered many other study results, agreed that the available evidence suggests that Bt cotton has greatly benefited Indian farmers (Areal et al., 2013; Carpenter, 2010; Finger et al., 2011; Gruère and Sengupta, 2011).

However, the available literature on Bt cotton impacts still has a number of shortcomings. First, most of the evidence is based on data from field trials or from the first few grow- 
ing seasons after the commercial release of Bt. This evidence is unsatisfying because it does not allow analysis of longer-term developments. For example, resistance build-up in pest populations or growing importance of secondary pests may potentially lower Bt benefits over time (Wang et al., 2009). Second, most impact studies do not properly control for nonrandom selection bias, which may occur when more successful farmers adopt the new technology earlier or more widely (Crost et al., 2007). As these successful farmers may have higher crop yields and profits anyway, this can result in inflated benefit estimates. Third, most available studies focus on agronomic impacts of Bt, such as yield and pesticide use effects, but economic effects, such as profit changes, are not analyzed at all or only based on simplistic comparisons. Fourth, and related to the previous point, many existing studies concentrate on impacts at the plot level, without considering possible broader welfare effects for farm households. In chapter 2 of this dissertation these shortcomings will be addressed.

\subsubsection{Hybrid Maize in Tanzania}

The impact of seed market liberalization and hybrid maize in Tanzania has not been studied. There are some studies on the impact of liberalization of fertilizer and grain markets but not of seed markets (Cooksey, 2011; Jayne et al., 2002; Ponte, 2001; Putterman, 1995). Also, research has been undertaken on the impact and adoption of hybrid maize in several other East African countries, some of which will be discussed after summarizing the economics of hybrids.

Hybrids $^{2}$ generally have higher vigor than nonhybrids (open-pollinated varieties), a phenomenon called heterosis effect. However, when they are recycled repeatedly they gradu-

\footnotetext{
${ }^{2}$ A hybrid in the most general sense is the result of a natural or deliberate cross of two distinctly genetically different plants of either two different species or two different races or identities within one species (Kingsbury, 2009). In another, henceforth implied meaning the term refers to the result of a deliberate cross of two inbred, pure lines within one species. This cross is also called "F1 hybrid" because today it is often the first filial genera-
} 
ally lose this advantage with every recycling step. The largest losses occur after the first recycling step. Therefore an incentive exists for farmers to use F1 hybrids every season, although F2 hybrids and further generations may still outperform nonhybrids (Minot et al., 2007). Associated with hybrids and more frequent replacements are higher costs of seed, which have to be weighed against the conferred benefit. Whether and by how much hybrids are more profitable for a farmer thus depends on their relative costs and yield (as well as related harvest cost). A further complication is that germplasm and local adaptation vary considerably between different hybrids and nonhybrids. Some nonhybrids yield more (and cost less) than some F1 hybrids. The question of impact depends on all these factors and requires data.

What is the empirical evidence concerning impacts of hybrids and other modern maize varieties (MVs) on farmers in Africa? Much of the literature cites large yield and income gains, but estimates are often based on trial data, partial budgeting from farm surveys, or correlation between aggregate production levels and MV adoption (Byerlee, 1996; Hassan et al., 2001; Heisey and Smale, 1995; Smale and Jayne, 2003). Potentially confounding factors, such as differences in soil quality, fertilizer use, or crop management are usually not controlled for (Morris, 2002). Econometric estimates of production models are rare; those that exist sometimes attribute little yield gains to MVs as opposed to fertilizer (De Groote et al., 2002). Hardly any study on modern maize varieties in Africa has looked beyond farm productivity to analyze impacts on household living standards. Hence, the available literature on MV impacts

tion of two pure lines that is grown by farmers (single cross). However, the early takeoff of hybrid seeds in the US was associated with double cross hybrids which resulted from crossing two single crosses. The double crosses were initially preferred because they were less costly to produce. It was only after improvements in hybridization technology occurred in the 1960s that single crosses began to take over (Olmstead and Rhode, 2008). In the literature, double crosses are sometimes referred to as F1 or F2 (Kingsbury, 2009; Olmstead and Rhode, 2008). In this dissertation, F1 is used to refer to fresh hybrids and F2 to hybrids recycled by the farmer. 
remains inconclusive. Chapter 3, dealing with the situation in Tanzania, will address some of these issues in detail to advance the state of the art.

The adoption rate of improved seeds in Sub-Saharan Africa is low, although they are available to a similar extent as in other developing countries (Byerlee and Heisey, 1996). The search for explanations has led to various constraints, including information, since being aware of a technology is a necessary condition for adoption (Diagne and Demont, 2007). Other commonly mentioned constraints are market imperfections for insurance and credit (Foster and Rosenzweig, 2010). The resulting policy recommendations are focused on alleviating such constraints through the provision of extension, insurance or credit. A recent study has pointed towards behavioral biases as a related but conceptually different set of constraints (Duflo et al., 2011). Farmers may have access to information, credit and insurance, but fail to behave rationally, for example by discounting myopically. The resulting policy implication consists of "nudges" that can correct these behavioral biases. A third possibility is that nonadoption is neither the result of constraints nor behavioral biases. Unconstrained, rational nonadoption means that the expected returns to adoption of a technology are negative or insignificant (Suri, 2011). Which of these factors is dominant in a particular situation is highly relevant for policies aimed at stimulating productivity growth in the small farm sector. Chapter 4 of this dissertation examines the various hypotheses and pits them against one another, with a particular focus on information constraints.

\subsection{Research Objectives and Outline}

As mentioned above, this dissertation has a threefold focus: the impact of Bt cotton in India, the impact of hybrid maize in Tanzania, and thirdly, the adoption of hybrid maize in Tanzania. The specific research questions addressed in this dissertation are as follows:

1. What are the impacts of Bt cotton on yield, profit and living standard of Indian farmers and how do these impacts develop over time? 
2. What are the impacts of hybrid maize on yield and living standard of Tanzanian farmers?

3. To what extent can information constraints explain nonadoption of hybrid maize in Tanzania?

The analyses rely on two household surveys: one extensive panel data set covering central and southern India, and one cross-sectional survey covering two regions in northern and eastern Tanzania. The Indian data were already available and not collected as part of this dissertation. These data are analyzed using fixed-effects econometric models. The Tanzanian data were gathered from a survey of 701 farmers which we conducted in cooperation with the International Maize and Wheat Improvement Center (CIMMYT) in late 2010. The impact analysis uses standard regression and instrumental variables (IV) techniques. For the adoption analysis of hybrid maize, an average treatment effect (ATE) framework is employed. Details on data collection and analysis are given in the respective chapters 2,3 , and 4 of the dissertation. Chapter 5 summarizes the main findings and concludes with some policy implications and possible directions for further research. 


\section{Economic Impacts and Impact Dynamics of Bt Cotton in India ${ }^{3}$}

Despite widespread adoption of genetically modified crops in many countries, heated controversies about their advantages and disadvantages continue. Especially for developing countries, there are concerns that GM crops fail to benefit smallholder farmers and contribute to social and economic hardship. Many economic studies contradict this view, but most of them look at short-term impacts only, so that uncertainty about longer-term effects prevails. We address this shortcoming by analyzing economic impacts and impact dynamics of Bt cotton in India. Building on unique panel data collected between 2002 and 2008, and controlling for nonrandom selection bias in technology adoption, we show that Bt has caused a $24 \%$ increase in cotton yield per acre through reduced pest damage and a 50\% gain in cotton profit among smallholders. These benefits are stable; there are even indications that they have increased over time. We further show that $\mathrm{Bt}$ cotton adoption has raised consumption expenditures, a common measure of household living standard, by 18\% during the 2006-2008 period. We conclude that Bt cotton has created large and sustainable benefits, which contribute to positive economic and social development in India.

\subsection{Introduction}

Despite widespread adoption of GM crops in many countries (James, 2011), controversies about their advantages and disadvantages continue. In the public debate, negative attitudes often seem to dominate. Civil society groups tend to emphasize potential risks of GM crops and question reports about positive agronomic and economic effects (FOE, 2011; Greenpeace,

\footnotetext{
${ }^{3}$ This chapter was published as: Kathage, J., Qaim, M., 2012. Economic impacts and impact dynamics of Bt (Bacillus thuringiensis) cotton in India. Proceedings of the National Academy of Sciences 109, 11652-11656.
} 
2010; Shiva et al., 2011; UCS, 2009). Especially with a view to developing countries, there are widespread concerns that GM crops fail to benefit smallholder farmers and contribute to social and economic hardship (FOE, 2011; Shiva et al., 2011). Much of this debate focuses on Bt cotton (Glover, 2010; Gruère and Sengupta, 2011; Qaim and Zilberman, 2003; Shiva et al., 2011; Stone, 2011), as this is currently the most widely used GM crop technology among smallholders. Using comprehensive data from India, we show that these concerns about negative social and economic impacts are not backed by representative empirical evidence.

Bt cotton contains genes from Bacillus thuringiensis that make the plant resistant to the cotton bollworm complex. This inbuilt insect resistance can lead to savings in chemical pest control and higher effective yields in farmers’ fields (Qaim and Zilberman, 2003). Several studies have shown that Bt cotton adoption is associated with significant benefits to farmers in various countries (Ali and Abdulai, 2010; Carpenter, 2010; Pray et al., 2002; Qaim, 2009; Subramanian and Qaim, 2010). In addition to productivity gains (Bennett et al., 2004, 2006; Crost et al., 2007; Morse et al., 2007; Sadashivappa and Qaim, 2009), Bt adoption entails reduced incidence of acute pesticide poisoning among smallholders (Kouser and Qaim, 2011). However, the available literature on Bt cotton impacts has four important shortcomings, which may also explain why controversies continue. First, with very few exceptions (Huang et al., 2010), most of the evidence is based on data from field trials or from the first few growing seasons after the commercial release of Bt varieties in a country. This evidence is unsatisfying because it does not allow analysis of longer-term developments. For example, resistance build-up in pest populations or growing importance of secondary pests may potentially lower Bt benefits over time (Tabashnik, 2008; Wang et al., 2008, 2009). Second, most impact studies do not properly control for nonrandom selection bias (Crost et al., 2007), which may occur when more successful farmers adopt the new technology earlier or more widely (Barrett et al., 2004). As these successful farmers may have higher crop yields and profits anyway, this can result in inflated benefit estimates. Third, most available studies focus on agronomic impacts 
of Bt, such as yield and pesticide use effects, but economic effects, such as profit changes, are not analyzed at all or only based on simplistic comparisons. Fourth, and related to the previous point, many existing studies concentrate on impacts at the plot level, without considering possible broader welfare effects for farm households.

We address these shortcomings by using comprehensive panel data collected in India in four waves between 2002 and 2008. Estimation of panel data models allows us to account for selection bias and also analyze impact dynamics. In particular, we estimate fixed-effects specifications of yield, profit, and consumption expenditure models to derive net impacts of Bt adoption on cotton yield per acre, profit per acre, and household living standard. To our knowledge, this economic impact assessment of any GM crop technology that builds on more than two years of panel data is unique.

\subsection{Results}

In India, cotton is primarily grown by smallholder farmers with farm sizes of less than 15 acres and cotton holdings of 3-4 acres on average. The first Bt cotton hybrids were commercially released in India in 2002. By 2011, 7 million farmers had adopted Bt on 26 million acres, around $90 \%$ of the total Indian cotton area (James, 2011). We carried out a survey of Indian cotton farmers in four waves between 2002 and 2008. This survey covered a total of 533 farm households in four principal cotton-producing states (see Materials and Methods). The sample is representative of Bt and conventional cotton farmers in central and southern India. Given that we purposively oversampled Bt adopters in the first wave, sample adoption rates differ from actual adoption rates. The share of Bt-adopting farmers in our sample was $38 \%$ in 2002. After a small decline in 2003, it increased to $46 \%$ in 2004. (In the 2004, 2006, and 2008 survey waves, we also asked farmers for their adoption of Bt hybrids in 2003, 2005, and 2007, respectively. However, further details about the cultivation experience were only asked for the respective survey years.) The adoption share jumped to $93 \%$ in 2005 and 
reached 99\% in 2008. A similar trend is also observed for individual adoption intensities, defined as the Bt acreage relative to the total cotton acreage on a farm. Alongside a range of household characteristics, data on all cotton plots of surveyed households were recorded, leading to a total of 1,655 plot observations.

Table 2.1 compares selected variables between Bt and conventional cotton plots and farms (for a more detailed overview, see Table A1). We differentiate between early (20022004) and late (2006-2008) adoption periods. Most previous studies on Bt cotton impacts in India concentrated on the early period; evidence for the later period is thin. Bt seed costs per acre were more than three times higher than conventional seed costs during the early period. During 2006-2008, the cost difference was lower because of government interventions in seed pricing and increasing competition in the market for Bt technology (Krishna and Qaim, 2008; Sadashivappa and Qaim, 2009). Pesticide costs were significantly higher on conventional plots than on Bt plots during 2002-2004, and there was no difference during 2006-2008. Widespread adoption of Bt has led to area-wide suppression of bollworm populations, so that conventional cotton farmers also substantially reduced their pesticide applications (Krishna and Qaim, 2012). Similar positive spillover effects were observed for Bt cotton in China and Bt maize in the United States (Hutchison et al., 2010; Wu et al., 2008).

In terms of yield per acre, Bt strongly outperformed conventional cotton in both time periods (Table 2.1). This finding is not because of higher yield potentials of Bt hybrids, but because of more effective pest control and thus lower crop losses. Higher yields are also the main reason for much higher profits on Bt cotton plots. These observed differences provide interesting insights into Bt effects, but they cannot be interpreted as net impacts of the technology, because confounding factors and possible nonrandom selection bias have to be controlled for. This process requires regression analysis. 
Table 2.1: Descriptive Statistics for 1,655 Plots and 533 Associated Households (Averages for 2002-2004 and 2006-2008)

\begin{tabular}{|c|c|c|c|c|}
\hline & \multicolumn{2}{|c|}{$2002-2004$} & \multicolumn{2}{|c|}{ 2006-2008 } \\
\hline & Conventional & $\mathrm{Bt}$ & Conventional & $\mathrm{Bt}$ \\
\hline \multicolumn{5}{|l|}{ Plot level information } \\
\hline Seed cost (1,000 Rs/acre) & $0.51(0.26)$ & $1.60 * * *(0.43)$ & $0.47(0.21)$ & $0.91 * * *(0.32)$ \\
\hline Pesticide cost $(1,000$ & $2.27 * * *(1.80)$ & $1.43(1.57)$ & $1.07(1.21)$ & $1.07(1.38)$ \\
\hline \multicolumn{5}{|l|}{ Rs/acre) } \\
\hline Yield (kg/acre) & $520.64(315.54)$ & $705.40 * * *(360.41)$ & 588.85 (318.66) & $829.03^{* * *}(341.08)$ \\
\hline Profit (1,000 Rs/acre) & $3.60(5.80)$ & $6.14 * * *(6.89)$ & $5.31(6.80)$ & $10.32 * * *(7.73)$ \\
\hline Number of plots & 601 & 298 & 64 & 692 \\
\hline \multicolumn{5}{|l|}{ Household level information } \\
\hline Land owned (acres) & $13.25(15.45)$ & $15.07 *(18.42)$ & $11.48(12.28)$ & $11.61(12.68)$ \\
\hline Expenditures $(1,000$ & $85.87(71.01)$ & $122.76 * * *(79.00)$ & $87.90(64.14)$ & $90.43(88.82)$ \\
\hline \multicolumn{5}{|l|}{ Rs/year) } \\
\hline Number of households & 363 & 222 & 61 & 432 \\
\hline
\end{tabular}

\subsubsection{Impact on Cotton Yield}

Results of panel fixed-effects specifications of a cotton yield function are shown in Table 2.2 (full model results with all control variables are shown in Table A2). The positive and significant coefficient of Bt in column 1 indicates that Bt has a positive net impact on cotton yield per acre. Controlling for all other factors, Bt increases cotton yield by $126 \mathrm{~kg}$ per acre, which is equivalent to a $24 \%$ gain over mean yields on conventional cotton plots. The Bt dummy variable captures Bt adoption in any year, whereas the additional Bt 2006-2008 dummy takes a value of one only when Bt was used in the 2006 or 2008 survey waves. In the first column, the Bt 2006-2008 coefficient is insignificant, indicating that the Bt yield effect was stable over time and did not increase or decrease in the later compared with the earlier period. 
Table 2.2: Net Impact of Bt on Cotton Yield and Profit per Acre

\begin{tabular}{lcccc}
\hline & \multicolumn{2}{c}{ Yield (kg/acre) } & \multicolumn{2}{c}{ Profit (Rs/acre) } \\
\cline { 2 - 5 } & 1 & 2 & 3 \\
\hline Bt (dummy) & $125.90^{* * *}(20.41)$ & $116.91^{* * *}(20.68)$ & $1,877.21^{* *}(889.16)$ & $2,151.51^{* *}(893.33)$ \\
Bt 2006-2008 & $3.59(43.46)$ & $180.06^{* * *}(20.54)$ & $-260.45(1,144.58)$ & $1,736.39^{* *}(803.31)$ \\
(dummy) & & & \\
2004 & $125.39^{* * *}(17.68)$ & & $2,066.07^{* * *}(466.18)$ & \\
2006 & $297.03^{* * *}(40.53)$ & $5,006.86^{* * *}(1,017.09)$ & 0.36 \\
2008 & $208.61^{* * *}(43.68)$ & & $2,332.61^{* *}(1,149.50)$ & $24.60^{* *}$ \\
$\mathrm{R}^{2}$ & 0.39 & 0.34 & 0.38 & $42.39 * * *$ \\
Hausman test & $90.47^{* * *}$ & $70.00^{* * *}$ & & \\
\hline
\end{tabular}

$* *, * * *$, Coefficient is statistically significant at the $5 \%$ and $1 \%$ level, respectively. Coefficient estimates are shown with standard errors in parentheses. Estimates are based on panel regressions with household fixed effects to control for nonrandom selection bias. The reference year is 2002. Not all variables included in the models (e.g., input quantities, prices, and other controls) are shown for brevity (full model results with all control variables are shown in Tables A2 and A3). The Hausman test results show that fixed-effects are preferred over random-effects specifications. Rs, Indian Rupees. Source: Author’s estimations.

The dummies for the three survey waves in column 1 of Table 2.2 are all positive and significant, indicating that overall yield levels were higher in 2004, 2006, and 2008, compared with the reference year 2002. Omitting these year dummies in column 2 leads to a large positive and significant Bt 2006-2008 coefficient. These results suggest that the Bt yield gain was in a magnitude of $297 \mathrm{~kg}$ per acre (sum of Bt and Bt 2006-2008 coefficients) in the later period and thus more than doubled compared with 2002-2004. As Bt adoption strongly increased over time, there is a close correlation between $\mathrm{Bt}$ 2006-2008 and the year dummies. Hence, some of the Bt effects are captured by the year dummies in column 1. Not including year dummies, as in column 2, may overestimate the Bt yield gains, because Bt 2006-2008 may then also capture time effects that are unrelated to the technology. However, systematic changes in temperature or rainfall did not occur during the period of analysis (GOI, 2012; Gruère and Sun, 2012), and there were also no other breakthrough technologies in Indian cotton production (Karihaloo and Kumar, 2009; Kouser and Qaim, 2011). Nor did we find evidence of attrition bias. (Because we have an unbalanced panel, there is the possibility of attri- 
tion bias, which could emerge when farmers who obtained lower than average yields with $\mathrm{Bt}$ cotton in 2002-2004 dropped out of the sample in the later 2006-2008 period. This drop could potentially hide a decrease in Bt impact over time. Analyses with different subsamples that we carried out do not support this hypothesis. We re-estimated the model in column 1 of Table 2.2 excluding the dropout farmers. With this smaller sample, the Bt coefficient is 130.94, which is very similar to the original coefficient of 125.90, and the Bt 2006-2008 coefficient remains insignificant. Hence, we conclude that there is no attrition bias.) Therefore, Bt was probably the main factor contributing to the observed time effects.

\subsubsection{Impact on Cotton Profit}

Bt technology can influence cotton profit mainly through three channels, namely changes in yield, changes in pesticide cost, and changes in seed cost (Qaim et al., 2006). To assess net profit changes per acre, we estimated fixed-effects specifications of a profit function (Table 2.2; full model results with all control variables are shown in Table A3). The coefficients in column 3 indicate that Bt increases profit by 1,877 Rs per acre (38 US\$), equivalent to a $50 \%$ profit gain over conventional cotton. In this specification, the Bt impact per acre does not change significantly over time. However, total cotton profits per farm rose, because farmers increased their Bt adoption intensity. Combining the estimate of 1,877 Rs with the data on adoption intensity, Bt added 5,307 Rs (107 US\$) to annual farm-level cotton profits during 2002-2004 and 10,524 Rs (213 US\$) during 2006-2008. Nationwide, for the 26 million acres currently under $\mathrm{Bt}$, this implies an annual net gain of almost 50 billion Rs (1 billion US\$) in cotton profits.

Similar to the yield analysis above, the year dummies in column 3 of Table 2.2 are all significant. When omitting these year dummies, the Bt 2006-2008 coefficient turns positive and significant (column 4), indicating that the Bt profit gains may actually have increased substantially in the later period to 3,888 Rs (79 US\$) per acre (sum of Bt and Bt 2006-2008 
coefficients). This result may partly be explained by lower Bt seed prices during 2006-2008. However, as seeds only account for a relatively small share of total production costs, the more important reason for larger profits per acre are higher yield gains and thus higher sales revenues.

\subsubsection{Impact on Household Living Standard}

Cotton is often the major crop for cotton-producing households in India, so that profit gains through Bt technology are also likely to increase household living standard. A common way of measuring living standard in the development literature is to look at household consumption expenditures, because expenditure is usually a more reliable indicator than income (Deaton, 1997). We use a fixed-effects specification of a consumption expenditure model. As the level of analysis is the household, instead of using dummy variables to capture Bt adoption, we use the households’ Bt area in any year and the Bt area in 2006-2008 as variables of particular interest. The results suggest that Bt had no significant effect on consumption expenditures in the early adoption period, but it increased household living standard significantly in the later period (Table 2.3; full model results with all control variables are shown in Table A4). This finding is plausible. Although Bt-adopting households also increased cotton profit during 2002-2004, they did not immediately change their consumption behavior but waited until they realized that the profit gains are sustainable.

In 2006-2008, each acre of Bt increased household consumption by 2,826 Rs (57 US\$) per year (Table 2.3). Based on this finding, we can also calculate the total living standard effect per household by multiplying with the mean Bt area of adopting farms. During 20062008, Bt-adopting households increased their annual consumption expenditures by 15,841 Rs (321 US\$) on average. Compared with nonadopters, this finding implies a net increase of 18\%, which underlines that Bt cotton has significantly raised living standards of smallholder farm households. 
Table 2.3: Net Impact of Bt on Household Living Standard

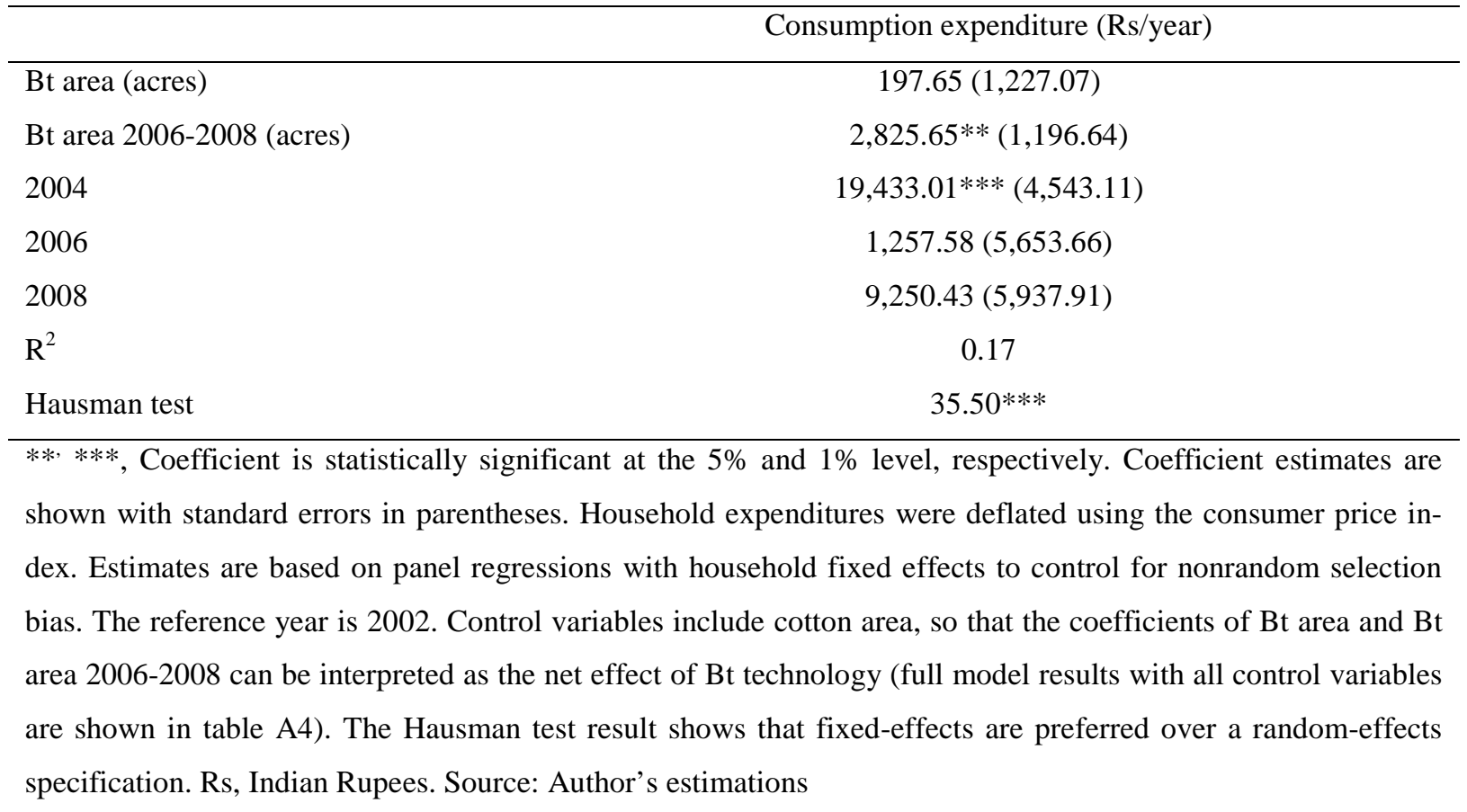

\subsection{Discussion}

The results show that $\mathrm{Bt}$ cotton adoption has caused sizeable socioeconomic benefits for smallholder farm households in India. The technology has increased cotton yields and profits by $24 \%$ and $50 \%$, respectively. These effects are similar in magnitude to the ones shown in earlier studies for India based on cross-section data (Bennett et al., 2004, 2006; Crost et al., 2007; Morse et al., 2007; Qaim et al., 2006; Sadashivappa and Qaim, 2009). The panel data used here confirm that impacts per acre of Bt cotton have been stable over time. Because of rapidly rising $\mathrm{Bt}$ adoption rates in India, the aggregate benefits increased tremendously. Countrywide, this technology is now used on $90 \%$ of the cotton area. On average, household living standard increased by 18\% among Bt adopters. Most of these adopting households are relatively poor. Hence, Bt cotton contributes to positive economic and social development.

The stable Bt effects per acre are a conservative interpretation. Robustness checks indicate that the per acre benefits probably increased over time. This finding could be explained by the growing number of available Bt hybrids and the release of new Bt events after 2005. In 
2002, only three Bt hybrids, which were developed by the Indian seed company Mahyco and contained Monsanto’s Bollgard I technology (event MON 531), were approved by the national regulatory authorities. In 2004 and 2005, three other Indian seed companies, which had sublicensed the Bollgard I technology, received approval for the commercialization of several additional Bt hybrids. In 2006, the number of approved Bt hybrids increased sharply. In addition, new Bt events were deregulated by the national authorities, including Monsanto's Bollgard II technology, but also technologies developed by public research institutes. By 2011, the number of commercialized Bt varieties and hybrids containing different events had increased to over 880 (James, 2011). More Bt events and greater varietal diversity imply effectiveness against a broader spectrum of insect pest species and better adaptation to different agroecological conditions.

Our findings of large and sustainable economic and social benefits of Bt cotton do not imply that impacts may not decrease in the long run. As of now, Bt resistance development and secondary pest outbreaks do not seem to be major problems in India, but this should be further monitored. Sustainable innovation in agriculture always implies that technologies are further improved or replaced by new technologies after some time. Nonetheless, our results clearly refute the assertion that Bt technology would harm smallholder farmers because of low and eroding economic benefits. As Bt cotton is the only GM crop technology that is already widely used by smallholder farmers, these findings may add to the wider public biotechnology debate.

\subsection{Materials and Methods}

\subsubsection{Survey}

A panel survey of Indian cotton farmers was carried out in four waves between 2002 and 2008. A multistage random sampling procedure was used. The survey covered four states of central and southern India, namely Maharashtra, Karnataka, Andhra Pradesh, and Tamil Na- 
du. These four states encompass a wide range of different cotton-growing situations. A total of 10 different districts and 63 villages were surveyed. The first wave was implemented in early 2003, covering the 2002 cotton growing season. Because this was the first season where Bt cotton was officially commercialized, the number of adopters was still very low. Therefore, Bt cotton adopters were purposely oversampled by randomly selecting from complete lists of technology users at the village level (Qaim et al., 2006). Follow-up waves were implemented in two-year intervals, in early 2005 (referring to the 2004 cotton season), early 2007 (referring to the 2006 season), and early 2009 (referring to the 2008 season). The survey is representative of $\mathrm{Bt}$ cotton adopters and nonadopters in central and southern India, where over $60 \%$ of the total Indian cotton area is located.

To some extent, sample attrition occurred over time, as is normal in panel surveys extending over several years. Some farmers had migrated to other areas, which happened particularly in one district of Karnataka. Other farmers had stopped cotton cultivation during the period, mostly because of focusing on new cash crops, such as sugarcane. Farmers who dropped out during the period were replaced by other randomly selected farmers in the same locations. The sample size was also slightly increased over time. In total, the sample includes observations from 533 different farm households, of which 198 were included in all four survey waves. All observations were used for the regression analysis, resulting in an unbalanced panel. An unbalanced panel allows more efficient estimation than any balanced subset of it (Baltagi and Song, 2006).

During face-to-face interviews in all four waves, farmers were asked to provide a wide array of agronomic and economic information, including input-output details on their cotton plots. Farmers who grew Bt and conventional cotton simultaneously provided details for both alternatives, so that the number of plot observations is somewhat larger than the number of farmers surveyed. The total number of cotton plot observations is 1,655 over the four waves. At the household level, data were collected about household structure, asset ownership, and 
living standard. Living standard is measured by household consumption expenditures (including the value of subsistence consumption), which were captured through a 30-day recall for food and other consumables, and a 12-month recall for more durable items.

\subsubsection{Regression Models}

We want to estimate unbiased treatment effects of Bt adoption on cotton yield per acre, profit per acre, and household living standard. For this purpose, we develop and estimate three types of models where Bt is included as an explanatory variable: a cotton yield function, a cotton profit function, and a household consumption expenditure model. These models can generally be represented as:

$$
y_{\mathrm{it}}=x_{\mathrm{it}} \beta+v_{\mathrm{it}},
$$

where

$$
v_{\mathrm{it}}=c_{\mathrm{i}}+\mu_{\mathrm{it}}
$$

where $y$ is the respective outcome variable (yield per acre, profit per acre, consumption expenditure per household), subscript $i$ is the plot or household observation, and subscript $t$ is time (survey wave). This fixed-effects specification allows for individual heterogeneity $c_{\mathrm{i}}$ to be correlated with the vector of explanatory variables $x_{\mathrm{it}}$. We use fixed effects because we suspect that more progressive and efficient farmers are more likely to adopt Bt technology. The existence of such selection bias and thus the superiority of a fixed-effects over a randomeffects specification is tested with a Hausman test.

Year dummies are included in the regression models to control for time fixed effects, using the first survey wave in 2002 as the reference year. For the yield and profit functions, which are estimated using plot observations, we use a Bt adoption dummy as treatment variable, which is one for a Bt plot in any particular year and zero otherwise. In addition, we include a Bt 2006-2008 dummy, which is one if Bt was used in 2006 or 2008. The Bt dummy indicates whether or not the technology has a positive net effect on cotton yield and profit, 
and the Bt 2006-2008 dummy reveals whether there are impact dynamics: if the Bt coefficient is positive and significant and the Bt 2006-2008 coefficient is statistically insignificant, then the technology causes benefits that do not change over time. On the other hand, a negative Bt 2006-2008 coefficient would indicate shrinking benefits, whereas a positive coefficient would reveal increasing benefits over time.

The consumption expenditure model is estimated at the household level. Some farm households have both $\mathrm{Bt}$ and conventional cotton. Moreover, the acreage cultivated with $\mathrm{Bt}$ varies. Therefore, instead of Bt dummies, we use two continuous Bt variables. The first such dummy is Bt area, which measures the number of acres cultivated with Bt on the farm, independent of the time period. The second is Bt area 2006-2008, which measures the number of Bt acres only during that later period. We control for total cotton area on the farm. Thus, the Bt estimation coefficients can be interpreted as the effects on household consumption expenditures per acre of Bt cotton. The test for impact dynamics is as explained for the yield and profit function models. 


\section{Seed Market Liberalization, Hybrid Maize Adoption, and Impacts on Smallholder Farmers in Tanzania}

Seed market liberalization, the growing role of proprietary technologies, and their impacts on smallholder farmers in developing countries are subjects of controversial debates. Here, we focus on Tanzania's maize sector. Since the early 1990s, seed market liberalization has attracted several foreign companies that now market maize hybrids in Tanzania. We analyze the impacts of proprietary hybrids on maize yield and household living standard, using recent survey data from smallholder maize farmers. Hybrid adoption rates are $49 \%$ and $12 \%$ in the north and east of Tanzania, respectively. Regression models show that average net yield gains are $50-60 \%$. These gains translate into significantly higher profit among hybrid adopters. However, geographical disaggregation reveals that the benefits have mostly occurred in the north, which also explains higher adoption there. In the north, hybrid adoption caused a 15\% increase in household living standard, whereas in the east no significant impact was observed. We conclude that proprietary hybrids can be suitable for semi-subsistence farms and that seed market liberalization has generated positive socioeconomic developments in Tanzania.

\subsection{Introduction}

In the 1980s and 1990s, many developing countries began to liberalize their seed markets. This has led to an increasing role of private sector companies. In some parts of Asia and Latin America, the private sector seed market share is already bigger than the public sector share (Naseem et al., 2010). Although still lower in magnitude, a growing private sector role can also be observed in Africa. Especially in maize, private sector breeding budgets and the pro- 
duction of proprietary seeds have increased remarkably over the last 20 years (Hassan et al., 2001; Langyintuo et al., 2010).

The wider implications of privatizing seed markets are not yet sufficiently understood and have been the subject of controversy. As private technology development and delivery mechanisms are often more efficient than public systems, farmers' access to new seed technologies might improve. Yet where market imperfections are widespread, as in most parts of rural Africa, privatizing seed markets might introduce a bias against smallholder farmers. Proprietary seeds may potentially increase farmers' dependence on private companies, especially when the industry is highly concentrated. Depending on prices of proprietary seeds and their suitability for smallholder conditions, some farmers may also be excluded from access to new crop technologies, which could exacerbate rural poverty and inequality (Lipton, 2010).

Maize is the most important staple food in Eastern and Southern Africa (Shiferaw et al., 2011). Most farmers in this region grow maize semi-subsistently. Despite the crop’s importance, average maize yields in Africa are low - around 2 t/ha, compared to a global average of over 5 t/ha (FAOSTAT, 2012). This yield gap is largely due to poor soils, drought, temperature stress, and low use of fertilizer and other agricultural inputs. Modern varieties (MVs), including improved open-pollinated varieties (OPVs) and hybrids, are grown on less than half of the total African maize area. In some countries, such as Zimbabwe and Kenya, adoption rates are above $70 \%$, while in many others they are only around 20\% (Langyintuo et al., 2010).

In most of the scientific literature, it is assumed that MVs are more beneficial to adopters than traditional varieties. Many studies also argue that nonadopters could benefit from adoption, particularly in cases where farmers face information or credit constraints. However, several activist groups claim that smallholder farmers would not benefit from MVs, especially not from proprietary hybrids (GRAIN, 2010b). This claim is based on several assumptions, namely that seed companies disseminate biased information about their products, 
that farmers are forced to buy seeds from monopolistic seed suppliers, or that farmers have trouble in understanding the suitability of new technologies for their particular context.

So what is the empirical evidence concerning impacts of modern maize varieties on farmers in Africa? Much of the literature cites large yield and income gains, but estimates are often based on trial data, partial budgeting from farm surveys, or correlation between aggregate production levels and MV adoption (Byerlee and Heisey, 1996; Hassan et al., 2001; Smale and Jayne, 2003). Potentially confounding factors, such as differences in soil quality, fertilizer use, or crop management, are usually not controlled for (Morris, 2002). Econometric estimates of production models are rare; those that exist sometimes attribute little yield gains to MVs as opposed to fertilizer (De Groote et al., 2005). Hardly any study on modern maize varieties in Africa looked beyond farm productivity to analyze impacts on household living standards. ${ }^{4}$ Hence, the available literature on MV impacts remains inconclusive.

Here, we address this research gap, focusing on the maize sector in Tanzania. While different authors have examined liberalization effects in fertilizer and grain markets in Tanzania (Cooksey 2011; Jayne et al., 2002; Putterman, 1995), seed market issues have hardly been analyzed. We describe seed market liberalization in Tanzania, pointing at the growing role of private seed companies and proprietary hybrids. Furthermore, we use recent household survey data and econometric techniques to assess the impact of hybrid maize adoption on crop yield, profit, and living standard. The results can also be interpreted as one impact of seed market privatization, because all maize hybrids that farmers in our sample used were developed by private companies, whereas all improved OPVs stem from public breeding programs.

The rest of this chapter is structured as follows. The next section provides an overview of liberalization in Tanzania's maize seed market. Then, the household survey data and some

\footnotetext{
${ }^{4}$ With very few exceptions (e.g., Kassie et al., 2011; Amare et al., 2012; Dibba et al., 2012) this also holds for MVs of other crops.
} 
descriptive statistics are presented, before the econometric approach and the estimation results are discussed. The last section concludes.

\subsection{Background}

\subsubsection{Seed Market Liberalization}

Liberalization refers to the removal of government regulations that impede the entry of private companies into a market that is dominated by state-owned enterprises (SOEs). Thus, liberalization can increase competition and consumer choice. In contrast, privatization has been given a variety of definitions (Dinavo, 1995). The most common use of the term relates to the sale of all or part of a government's equity in SOEs to the private sector, or the placing of SOEs under private management through leases and management contracts (Vickers and Yarrow, 1988). However, Dinavo (1995) lists liberalization as one of eight commonly used forms of privatization. Others stress that liberalization does not necessitate privatization in the narrow sense and that privatization may be ineffective unless it is accompanied by liberalization, because privatization alone does not automatically entail more competition (Van de Walle, 1989). In this chapter, the two terms liberalization and privatization are used interchangeably, because it is the reduction or removal of policy barriers and the resulting entry of private companies in a seed market formerly dominated by SOEs that we are particularly interested in.

A common avenue for private companies to participate in the seed market is via hybrids. Hybrid seeds refer to the first filial generation (F1) cross of two distinct lines of a plant. Through heterosis, F1 hybrids exhibit more vigor than OPVs, leading to higher vitality and yields. However, sowing the harvest of F1 hybrids (recycling) results in a reduction in vigor and consequently lower yields as compared to the F1. Yields of recycled F1 hybrids may still exceed those of OPVs for several generations (Japhether et al., 2006), although this depends on a number of factors. In any case, the hybrid vigor in the F1 provides an incentive for farm- 
ers to purchase seeds more frequently. Thus, private seed companies can recover their costs and make profit from regular sales even without legal restrictions to seed recycling (Pray and Ramaswami, 1991).

Several studies have analyzed the situation in India, where seed markets have been liberalized since the 1980s (Kolady et al., 2012; Matuschke et al., 2007; Matuschke and Qaim, 2008; Pray et al., 2001; Tripp and Pal, 2001). Pray et al. (2001) and Kolady et al. (2012) noted a significant increase in research and development investments by private seed companies in India, which they largely attribute to policy reforms. Matuschke et al. (2007) and Matuschke and Qaim (2008) showed that innovation rates in seed markets increased after liberalization, and that proprietary hybrids of wheat and millet are superior to most public sector varieties. Tripp and Pal (2001) found that the private sector also engaged in multiplication and marketing of publicly bred varieties and hybrids. A common finding of these studies is that the entry of private companies in seed markets has brought sizeable benefits to many Indian farmers, including smallholders.

Much less evidence is available for the consequences of seed market liberalization in Sub-Saharan Africa. The evidence from India may not be easily transferrable, because the conditions are quite different.

\subsubsection{Seed Market Liberalization in Tanzania}

After independence in 1961, Tanzania turned to African Socialism. The Arusha Declaration of 1967 was followed by a massive nationalization of the major means of production. Smallholder farmers were supposed to live in groups and share basic services (villagization). By 1979, a total of 380 parastatals had been registered, and by June 1990 the number had increased to 425. During this era of socialism, private sector involvement in agriculture was very small. In the 1980s, the international donor community (the IMF and the World Bank in particular) increasingly demanded economic reforms due to severe structural problems. Tan- 
zania ultimately accepted to take measures of structural adjustment (Due, 1993; Limbu and Mashindano, 2002).

Public maize research in Tanzania began in the 1960s. The National Maize Research Program was launched in 1974 and released about 15 improved maize varieties until the mid1990s, including several hybrids. The government-owned Tanzania Seed Company (Tanseed) was the only producer of certified maize seeds until the early 1990s, when private companies were for the first time allowed to enter the market (De Groote et al., 2002).

In 1993, Cargill became the first private company to release a maize hybrid in Tanzania. Pannar, a South African company, entered the market in 1995. They were followed in 1999 by Monsanto and Pioneer, in 2000 by Kenya Seed and in 2001 by Seed Co from Zimbabwe. Fica Seed, Tanseed International (founded in 2002 after the government-owned company collapsed) and Western Seed released their first maize hybrids in subsequent years (Table 3.1). Langyintuo et al. (2010) report that the number of registered maize seed companies grew from 2 in 1997 to 14 in 2007. Based on seed sales, they estimate that $18 \%$ of the national maize area was under MVs in 2007, up from 4\% in 1997. If farmer recycled seeds are inclu-

Table 3.1: Maize Hybrids Released by the Private Sector, 1993-2007

\begin{tabular}{lccc}
\hline Company (year of first release) & $1993-1997$ & $1998-2002$ & 2003-2007 \\
\hline Cargill (1993) & 3 & 1 & - \\
Pannar (1995) & 4 & 4 & 5 \\
Monsanto (1999) & - & 3 & - \\
Pioneer (1999) & - & 5 & 4 \\
Kenya Seed (2000) & - & 1 & 4 \\
Seed Co (2001) & - & - & 3 \\
Fica Seed (2003) & - & - & 3 \\
Tanseed International (2006) & - & - & 3 \\
Western Seed (2007) & - & 19 & 22 \\
Total & 7 & & \\
\hline
\end{tabular}

Source: Tanzania Official Seed Certifying Institute. 
ded, the MV share will be somewhat larger, but nationally representative data are not available. Hybrids and improved OPVs respectively made up 65\% and 35\% of the total volume of MV sales in 2006/2007 (Langyintuo et al., 2010).

\subsection{Data and Descriptive Analysis}

\subsubsection{Survey}

A household survey was conducted in the eastern and northern zones of Tanzania in late 2010. These two zones represent two main agroecological climates of Tanzania, highlands (north) and lowlands (east). Within these two zones, four districts (Mvomero, Kilosa, Karatu, Mbulu) from three regions (Morogoro, Arusha, Manyara) were deliberately selected. Then, 30 wards and 60 villages were randomly selected. At the village level, households were sampled randomly, taking district level population sizes into account. In each zone, 350 households were selected, resulting in a total sample size of 700 households. Out of these, 695 grew maize.

The household head of each household was taken through a structured interview, providing detailed information on household composition, location and infrastructure, social capital, asset ownership, agricultural production, and other economic activities. Input and output data for cropping activities were captured for all plots on a farm, so the number of plot observations is larger than the number of households surveyed. Cropping details refer to the 2008/2009 season. Household level food consumption data were collected through a 7-day recall and non-food consumption data through a 12-month recall for 2009/2010. Thus, the consumption data can be linked to the previous agricultural season.

\subsubsection{Descriptive Analysis}

The average farm size in our sample is around 5 acres. This is in line with census data from Tanzania. Of all maize growers, 31\% used maize hybrids at least on a part of their total maize 
area; $9 \%$ were partial adopters and 21\% were full adopters in 2008/2009. Adoption patterns differ between zones. In the north, partial adoption was observed for $14 \%$ and full adoption for $34 \%$, whereas in the east, partial and full adoption was observed for only $5 \%$ and $8 \%$, respectively. Aggregate adoption rates were $49 \%$ in the north and $12 \%$ in the east. Considering the total maize area of farms in our sample, $23 \%$ was cultivated with hybrids. This includes recycled hybrids, which were grown on almost one-quarter of the total hybrid area. All hybrids used by sample farmers were of private origin, and all seeds of private origin were hybrids (all improved OPVs were of public origin). We can thus equate private origin with hybrids for the purpose of this analysis.

The relatively low adoption rates of hybrids may be due to the fact that suitable hybrids are not available for all locations. Thus, available maize hybrids may not be beneficial for all farmers. On the other hand, limited awareness may also play a role. Of all farmers in our sample, 38\% reported that they had never heard about any maize hybrid. This share is higher in the east than in the north.

Seven different hybrids were used on the 291 hybrid maize plots in our sample. The dominant hybrid was SC627, which was grown on 56\% of the plots, followed by DK8031 with a share of $19 \%$. The remaining five hybrids were from Pannar and Kenya Seed, each accounting for less than $10 \%$ of the hybrid plots in our sample.

Some sample descriptive statistics at the plot level are shown in Table 3.2. Each farmer has 1.6 maize plots on average. The amount of seed used was higher on hybrid plots than on nonhybrid plots. Around one-quarter of the hybrid plots were planted with recycled hybrids, whereas seed recycling was observed on two-thirds of the nonhybrid plots. Intercropping of maize, mostly with legumes, was practiced on $82 \%$ and $57 \%$ of the hybrid and nonhybrid plots, respectively. Intercropping can potentially contribute to higher maize yields due to the ability of legumes to fix atmospheric nitrogen. On the other hand, intercropping might reduce the amounts of other nutrients and water available for maize, especially under 
Table 3.2: Descriptive Statistics at the Plot Level

\begin{tabular}{lcc}
\hline & Hybrids & Nonhybrids \\
\hline Seed rate (kg/acre) & $9.99^{* *}(31.21)$ & $7.49(5.94)$ \\
Intercropped (share of plots) & $0.82^{* * *}(0.38)$ & $0.57(0.49)$ \\
Fertilizer use (share of plots) & $0.03(0.18)$ & $0.04(0.21)$ \\
Fertilizer (kg/acre) & $1.99(11.73)$ & $1.33(8.70)$ \\
Manure use (share of plots) & $0.45^{* * *}(0.50)$ & $0.23(0.42)$ \\
Manure (kg/acre) & $533.93^{* * *}(1,128.11)$ & $179.42(584.80)$ \\
Pesticide (l/acre) & $0.025^{* * *}(0.125)$ & $0.006(0.055)$ \\
Irrigation (share of plots) & $0.01(0.10)$ & $0.005(0.07)$ \\
Labor (days/acre) & $19.05^{*}(14.44)$ & $17.75(14.42)$ \\
Yield (kg/acre) & $742.66^{* * *}(916.78)$ & $437.09(755.26)$ \\
Total cost (1000 TSh/acre) & $44.9^{* * *}(52.6)$ & $21.0(33.5)$ \\
Number of plots & 291 & 826 \\
\hline
\end{tabular}

$*, * *, * * *$ imply that the mean value is significantly higher than that of nonhybrids at the $10 \%, 5 \%$ and $1 \%$ level, respectively. Mean values are shown with standard deviations in parentheses. Total cost includes costs of purchased fertilizer, manure, seed, herbicide, pesticide, and hired labor. All data refer to the 2008/2009 season. TSh, Tanzanian Shilling. Source: Author’s calculations.

dry conditions. Virtually all maize was produced under rainfed conditions. Mineral fertilizer was applied to only 3-4\% of all maize plots, with no significant difference between hybrids and nonhybrids. Likewise, pesticide use was very low. Manure application was more common, especially on hybrid plots. Maize yields were quite low in an international comparison, but they were significantly higher for hybrid than for nonhybrid maize (Table 3.2).

The cost of production was also higher on hybrid than on nonhybrid plots. This is partly due to seed costs, which were twice as high for hybrids. Moreover, some differences in the cost of other inputs were observed. Nonetheless, the higher yields and revenues (including the market value of home-consumed maize) of hybrids outweighed the higher costs, so that hybrid adoption was associated with significantly higher profit (Figure 3.1).

Table 3.3 shows some descriptive statistics at the household level, disaggregated by hybrid adoption status. While full adopters were slightly more educated than partial adopters and nonadopters, there were no significant differences in terms of farm size and total maize area cultivated. Yet, due to yield differences, maize production is higher among full and part- 


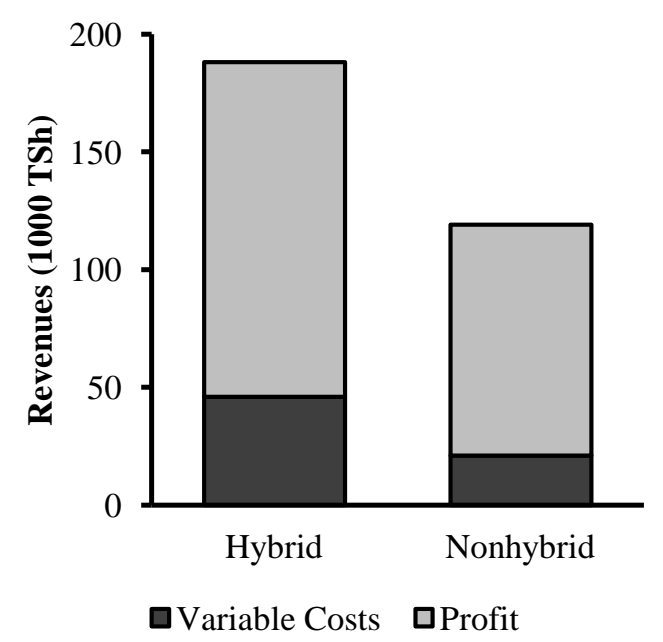

Figure 3.1: Profit Analysis (Source: Author's calculations)

ial adopters as compared to nonadopters. About half of all households sell some maize; the rest produce maize only for home consumption. These shares were almost equal across the three groups. But in quantity and value terms, maize sales and consumption were significantly higher among adopters than among nonadopters. We use household expenditure and consumption data to assess living standard. Expenditures for market consumption were slightly higher among adopters than among nonadopters. On the other hand, and somewhat surprisingly, the value of nonmarket consumption was lowest among the full adopters. In terms of total consumption values, no significant differences could be observed.

There were notable differences in plot and household level characteristics between north and east. Significant differences in maize yield between hybrids and nonhybrids were observed in the north but not in the east. Likewise, total maize production and home consumption were higher among hybrid adopters in the north, but not in the east. This suggests that hybrid maize adoption is not beneficial in the east, which could explain the low adoption rates in that zone. Interestingly, mostly the same hybrids were used in both zones, although the agroecological conditions are different. It appears that the hybrids available are much better suited to the higher altitudes in the north, while there is no productivity advantage in low- 
Table 3.3: Descriptive Statistics at the Household Level

\begin{tabular}{lccc}
\hline & Full adopter & Partial adopter & Nonadopter \\
\hline Household size (head) & $5.91^{(3)}(2.53)$ & $6.08^{(3)}(2.19)$ & $5.39(2.36)$ \\
Education of farmer (years) & $6.01^{(2),(3)}(3.15)$ & $5.23(3.11)$ & $5.03(3.21)$ \\
Land owned (acres) & $5.44(10.49)$ & $5.12(3.90)$ & $5.14(5.39)$ \\
Maize area (acres) & $3.21(3.02)$ & $3.76^{(1)}(1.55)$ & $3.53(4.33)$ \\
Hybrid maize area (acres) & $3.21^{(2),(3)}(3.03)$ & $1.46^{(3)}(0.79)$ & $0.00(0.00)$ \\
Maize production (kg/year) & $2,530^{(3)}(6,681)$ & $1,704^{(3)}(1,558)$ & $1,301(2,286)$ \\
Own maize consumption (kg/year) & $975^{(3)}(1,350)$ & $899^{(3)}(722)$ & $701(987)$ \\
Maize sold (share of households) & $0.53(0.50)$ & $0.52(0.50)$ & $0.51(0.50)$ \\
Maize sold (1000 TSh/year) & $302^{(3)}(103)$ & $235^{(3)}(910)$ & $121(273)$ \\
Other crops sold (1000 TSh/year) & $609^{(3)}(2,622)$ & $325^{(3)}(552)$ & $198(414)$ \\
Food expenditures (1000 TSh/year) & $938(925)$ & $911(940)$ & $867(914)$ \\
Nonfood expenditures (1000 TSh/year) & $649^{(3)}(1,048)$ & $494(295)$ & $480(564)$ \\
Nonmarket consumption (1000 TSh/year) & $389(385)$ & $624^{(1)}(1,042)$ & $566^{(1)}(878)$ \\
Total consumption (1000 TSh/year) & $1,975(1,742)$ & $2,029(1,480)$ & $1,948(1,653)$ \\
Number of households & 149 & 65 & 481 \\
\hline (x) implies that the mean value is significantly higher than that in column x at the 10\% level. Mean values are \\
shown with standard deviations in parentheses. Food consumption from own production is valued at local market \\
prices. All data refer to the 2008/2009 season, except for sales and expenditures data (2009/2010). TSh, Tanza- \\
nian Shilling. Source: Author’s calculations.
\end{tabular}

land areas. Suitable hybrids for the eastern zone have hardly been commercialized up till now.

\subsection{Econometric Approach}

The previous section has shown that there were differences in maize yield between hybrid adopters and nonadopters, while there were no significant differences in household consumption. However, these comparisons do not necessarily reveal net impacts of hybrid adoption, because potentially confounding factors have to be controlled for. This requires an econometric approach. We assume that farmers choose between using hybrid or nonhybrid seeds on a given maize plot and thus try to maximize their utility from growing maize. We model the decision in a random utility framework (e.g., Feder et al., 1985), in which household $h$ chooses hybrid over nonhybrid seeds on plot $p$ if the utility from adopting hybrids, $U_{\mathrm{hpA}}$, exceeds 
the utility of not adopting hybrids, $U_{\mathrm{hpN}}$. The difference between these two utilities can be written as $T_{\mathrm{hp}}^{*}=U_{\mathrm{hpA}}-U_{\mathrm{hpN}}$. Because utilities cannot be observed directly, we express $T_{\mathrm{hp}}^{*}$ as a function of a vector of observable variables $V_{\mathrm{hp}}$ :

$$
T_{\mathrm{hp}}^{*}=\sigma V_{\mathrm{hp}}+\varepsilon_{\mathrm{hp}} \cdot
$$

Using a binary specification, $T_{\mathrm{hp}}$ is a dummy variable that equals 1 if the household uses hybrid seeds on plot $p$, and zero otherwise. $\sigma$ is a vector of parameters, and $\varepsilon_{\mathrm{hp}}$ is a random disturbance term. Note that the number of adoption decisions a household faces is equal to the number of maize plots. Since $T_{\mathrm{hp}}^{*}$ may differ between plots, a utility-maximizing household could opt for hybrids on some but not all plots.

We examine the impacts of hybrid adoption on two outcome variables, namely maize yield per acre and household living standard. Living standard is measured in terms of household consumption, including market expenditures and the value of home consumption. The basic econometric model is as follows:

$$
Y=\gamma X+\beta Z+\mu
$$

where $Y$ is the outcome variable of interest, and $X$ is the treatment variable capturing hybrid adoption. In the plot-level yield model, $X$ is a dummy that is equal to $T_{\mathrm{hp}}$. In contrast, $X$ is a truncated continuous variable measuring the number of acres under hybrid maize in the household-level consumption model. The estimates of the coefficients $\gamma$ are used to infer the impacts of hybrid maize adoption on the two outcome variables. $Z$ is a vector of covariates, including plot-level inputs such as fertilizer and labor, as well as household-level characteristics such as education and farm size (further details below). $\mu$ is a random error term. The functional form is chosen according to theoretical and empirical fit. Several specifications are implemented in order to check the robustness of the results.

One potential issue is endogeneity of hybrid adoption in the yield and consumption models. A common source of endogeneity in impact assessment is non-random selection into 
treatment, which can lead to selection bias (Deaton, 2010; Dibba et al., 2012; Fischer and Qaim, 2012). A common method to address issues of endogeneity is IV regression, which requires valid instruments. An instrument is an observed variable that is correlated with the potentially endogenous variable but uncorrelated with the outcome variable. These two conditions for validity can be assessed using tests of under- and overidentification (Kennedy, 2008). We tried several potential candidates, but unfortunately could not find a strong and valid instrument for hybrid adoption. This is further elaborated in the next section. Yet we use other robustness checks to test whether the adoption treatment effects on yield and household living standard are potentially biased.

Selection bias would occur if adoption is correlated with unobserved factors that also influence the outcome variables directly. Hence, the problem is essentially an omitted variable bias. If the unobserved variable were included in the model, the estimated treatment effect of hybrid adoption might change (Kennedy, 2008). Typical unobserved factors that may influence technology adoption and also yield and living standard are the farmers' ability and motivation (Kathage and Qaim, 2012; Matuschke et al., 2007). If one can find observed variables that are likely correlated with ability and motivation, one could use them as additional proxies and observe whether their inclusion into the model affects the adoption treatment effect. Certain factors - like farmers' age, education, and geographical differences - may be included in any case, as they are expected to influence the outcome directly. Other proxies may not have an immediate theoretical justification, but they can still be used in auxiliary regressions to identify potential bias. We use various proxy variables to test for the robustness of the estimated treatment effects. 


\subsection{Regression Results and Discussion}

\subsubsection{Impact on Maize Yield}

Estimation results for the plot-level maize yield model are shown in Table 3.4. We employ a Cobb-Douglas functional form with inputs and output expressed in natural logarithms. This form allows for decreasing marginal returns to inputs and showed the best empirical fit in comparison to alternative functional forms. The explanatory variable of particular interest is the hybrid adoption dummy. Further, we control for inputs such as fertilizer, pesticides and labor, and for farmer characteristics such as age and education. In addition, we include dummies for intercropping, irrigation, and good soil quality, which may also influence yield levels. Results in column 1 indicate that hybrids raise yields by $48 \%{ }^{5}$ In column 2 , we add an additional dummy for recycled hybrids. While the coefficient of this additional dummy is not statistically significant, it is negative and causes the hybrid treatment effect to increase. The coefficient of 0.46 implies a hybrid yield gain of 58\%. Comparison with column 1 suggests that higher productivity can be achieved when fresh F1 seeds are used every season. On the other hand, these results also suggest that recycled hybrids still outperform OPVs on average.

In column 3 of Table 3.4, we add a dummy for the northern zone. As pointed out above, agroecological conditions differ between the north and the east, which may affect maize yields. There may also be other geographical differences, including relevant unobserved factors that are controlled for by the north dummy. ${ }^{6}$ However, the estimates reveal no

\footnotetext{
${ }^{5}$ Coefficients of dummies in models with a log-dependent variable are interpreted as in Halvorsen and Palmquist (1980), that is, [exp(coefficient)-1] x 100.

${ }^{6}$ For instance, there may be geographical differences in farmers' motivation to achieve high maize yields. If maize is the dominant staple food, farmers may put more effort into this crop than if maize is only one among several important food crops. Analysis of crop production patterns in our sample shows that farmers in the north produced a smaller range of staples than farmers in the east. In the north, maize, haricot bean, and pigeonpea were dominating crop production, while farmers in the east frequently grew rice, potatoes, cassava, tomatoes, and bananas, in addition to maize. Hence, the geographical dummy may capture unobserved motivational factors
} 
Table 3.4: Estimated Coefficients of the Yield Model

\begin{tabular}{|c|c|c|c|c|}
\hline & \multicolumn{4}{|c|}{ Maize yield in 2008/2009 (kg/acre) } \\
\hline & 1 & 2 & 3 & 4 \\
\hline Hybrid (dummy) & $0.39 * * *(0.09)$ & $0.46^{* * *}(0.10)$ & $0.45^{* * *}(0.11)$ & $0.56 * * *(0.12)$ \\
\hline Hybrid recycled (dummy) & & $-0.28(0.18)$ & $-0.27(0.18)$ & $-0.18(0.19)$ \\
\hline Intercropping (dummy) & $-0.16 *(0.09)$ & $-0.15 *(0.09)$ & $-0.17 *(0.10)$ & $-0.17 *(0.10)$ \\
\hline Seed amount (kg) & $0.12 * *(0.05)$ & $0.12 * *(0.05)$ & $0.12 * *(0.05)$ & $0.11^{* *}(0.05)$ \\
\hline Fertilizer (kg) & $-0.04(0.16)$ & $-0.04(0.16)$ & $-0.04(0.16)$ & $-0.03(0.16)$ \\
\hline Manure (kg) & $0.17 * * *(0.05)$ & $0.17 * * *(0.05)$ & $0.16^{* * *}(0.05)$ & $0.16 * * *(0.05)$ \\
\hline Herbicide (kg) & $0.55(0.68)$ & $0.56(0.68)$ & $0.54(0.68)$ & $0.55(0.68)$ \\
\hline Pesticide (kg) & $-0.08(0.13)$ & $-0.08(0.13)$ & $-0.09(0.13)$ & $-0.10(0.13)$ \\
\hline Irrigation (dummy) & $0.49(0.53)$ & $0.55(0.53)$ & $0.53(0.53)$ & $0.48(0.53)$ \\
\hline Labor (days) & $0.50 * * *(0.06)$ & $0.50 * * *(0.06)$ & $0.50 * * *(0.06)$ & $0.50 * * *(0.06)$ \\
\hline Good soil quality (dummy) & $0.26^{* * *}(0.10)$ & $0.25 * *(0.10)$ & $0.25 * *(0.10)$ & $0.25 * *(0.10)$ \\
\hline Age of farmer (years) & $0.002(0.004)$ & $0.001(0.004)$ & $0.001(0.004)$ & $0.001(0.004)$ \\
\hline Education of farmer (years) & $0.01(0.01)$ & $0.01(0.01)$ & $0.01(0.01)$ & $0.01(0.01)$ \\
\hline $\begin{array}{l}\text { Maize experience of farmer } \\
\text { (years) }\end{array}$ & $-0.01 *(0.004)$ & $-0.01 *(0.004)$ & $-0.01 *(0.004)$ & $-0.01 *(0.004)$ \\
\hline North & & & $-0.05(0.11)$ & $-0.03(0.12)$ \\
\hline Hybrid-east interaction & & & & $-0.50 * *(0.22)$ \\
\hline Constant & $3.89 * * *(1.02)$ & $3.93 * * *(1.02)$ & $3.91^{* * *}(1.02)$ & $3.91 * * *(1.02)$ \\
\hline Number of observations & 1117 & 1117 & 1117 & 1117 \\
\hline $\mathrm{R}^{2}$ & 0.15 & 0.15 & 0.15 & 0.15 \\
\hline
\end{tabular}

$*, * *, * * *$, Coefficient is statistically significant at the 10\%, 5\% and 1\% level, respectively. Coefficient estimates are shown with standard errors in parentheses. Maize yield, seed amount, fertilizer, manure, herbicide, pesticide, and labor are expressed in natural logarithms. Dummies for zero input use were used, as suggested by Battese (1997), but are not shown here for brevity. The reference region is east. Source: Author’s estimations.

significant effect of the north dummy; and the coefficient of hybrid adoption remains almost unaffected. In column 4, we add an interaction term of hybrid adoption and east. This is instructive to analyze geographical differences in the hybrid treatment effect, which we expect based on the descriptive analysis discussed above. Indeed, the coefficient of this interaction term is negative and highly significant. At the same time, the coefficient of the hybrid dummy itself increases substantially. These results confirm geographical differences in impact. In the that could potentially bias the hybrid treatment effect if not controlled for. We can assess potential bias by comparing the coefficients on hybrid adoption in regressions with and without the geographical dummy. 
north, hybrid adoption increases yield by $75 \%$, while in the east adoption is not associated with a significant yield effect. A Wald test failed to reject the null hypothesis that the sum of the coefficients on hybrid and the interaction term is equal to zero. As mentioned, this is likely due to the fact that maize hybrids well suited for the agroecological conditions in the east have not been developed. This also explains the low hybrid adoption rates in the east.

Even though we tried to include a comprehensive set of covariates that help to avoid selection bias, hybrid adoption may still be endogenous if unobserved heterogeneity is not properly controlled for. To control for such potential bias, we tried to identify suitable instruments. As discussed above, to be eligible as an instrument a variable must have a statistical relationship with hybrid adoption but not with yield (Deaton, 2010; Kennedy, 2008). We tested several infrastructure variables such as distance to the output market, distance to the input dealer, and road quality, which are exogenous themselves and meet the general criteria. Unfortunately, however, their correlation with hybrid adoption is not strong enough to form suitable instruments, either individually or in combination. This was tested in several IV regressions. As an alternative, we tried a dummy for religious affiliation. In Tanzania, Christianity and Islam are the two most important religions. Adhering to Islam (19\% of the sample) is negatively correlated with adoption, but again the correlation turned out to be not strong enough for an IV regression. Unfortunately, we could not identify valid and strong instruments for hybrid adoption.

Another approach to test for selection bias is through auxiliary regressions with additional proxies that may be correlated with relevant unobserved factors (see explanations in previous section). We start by using the same variables as proxies that were already tried as instruments. For instance, infrastructure conditions may affect farmers’ motivation and access to information. Religion may influence farming practices and attitudes. The hybrid treatment effects on yield with the inclusion of such additional proxies are shown in the upper part of 
Table 3.5. ${ }^{7}$ The other covariates are those that were included in column 4 of Table 3.4, where we identified a hybrid treatment effect of 0.56 . Columns 1 to 3 of Table 3.5 show that this treatment effect hardly changes through inclusion of the additional proxies. A completely different proxy that we tested is the height-for-age z-score of preschool children, a standard measure for child nutrition. ${ }^{8}$ One could imagine that child nutrition is partly determined by the parents’ physical and cognitive ability, which could also influence maize yields. Column 4 of Table 3.5 shows that the hybrid treatment effect actually increases when height-for-age zscores are included. But it should be noted that the number of observations in this auxiliary

Table 3.5: Treatment Effects of Hybrid Adoption in Yield and Consumption Models with Different Proxies Added

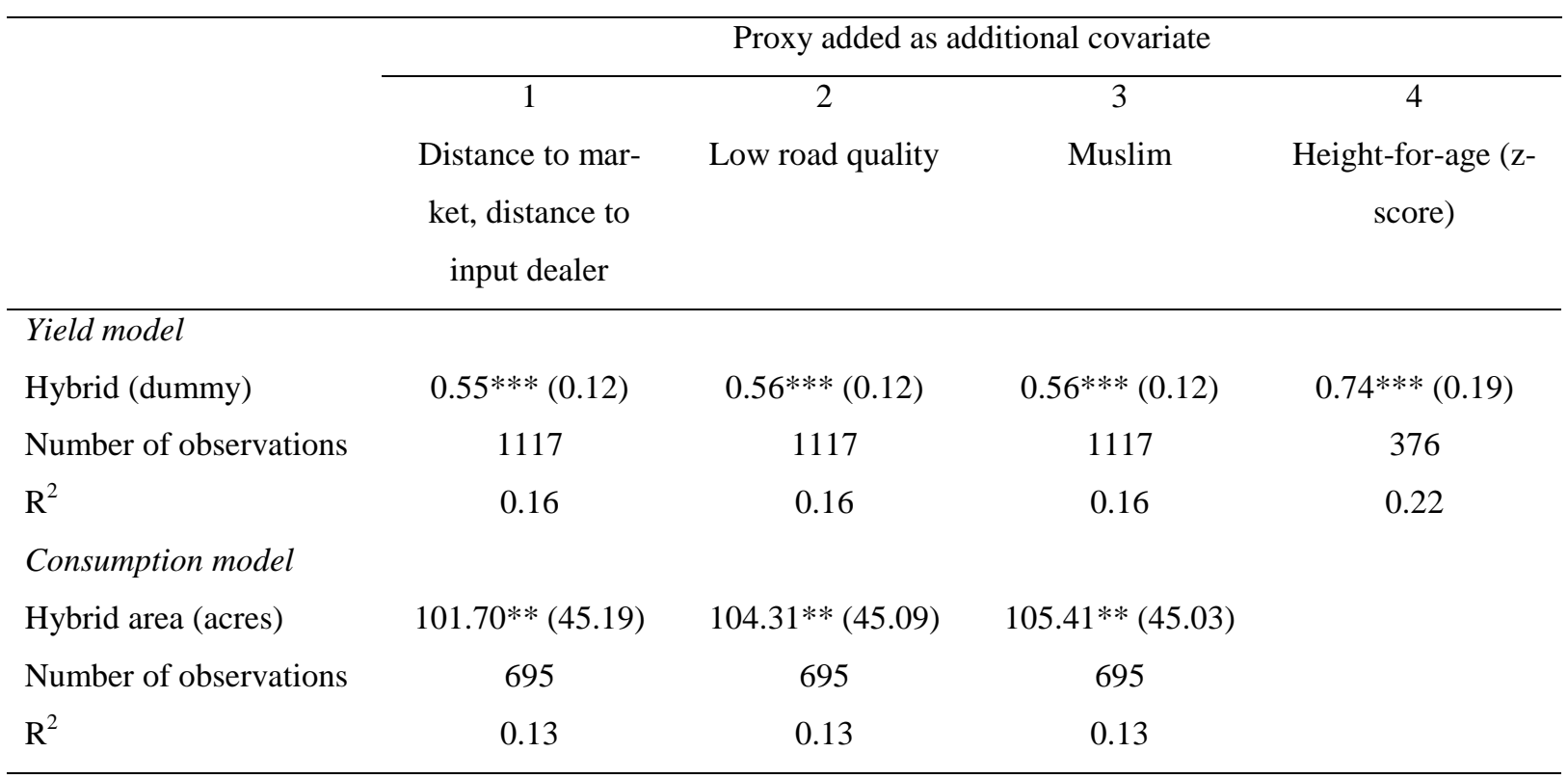

**, ***, Coefficient is statistically significant at the $5 \%$ and $1 \%$ level, respectively. Coefficient estimates are shown with standard errors in parentheses. Covariates in the yield model include those from column 4 in table 4. Covariates in the consumption model include those from column 3 in table 6. Covariates not shown for brevity. Source: Author's estimations.

\footnotetext{
${ }^{7}$ The lower part of Table 3.5 shows robustness tests for the treatment effects on household living standard. These results are discussed further below.

8 For calculation of z-scores, we used the World Health Organization Child Growth Standards (http://www.who.int/childgrowth/standards/en/)
} 
model is much smaller, because child anthropometric data were only collected in 220 households (with 376 maize plots). Hence, this change in the treatment effect should not be overinterpreted. We conclude that the yield treatment effect is robust. It does not seem to suffer from significant selection bias; at least there is no evidence that the effects identified in Table 3.4 are overestimated.

\subsubsection{Impact on Household Living Standard}

We have shown that hybrid adoption has a positive impact on maize yield at the plot level. Hybrid adoption also increases maize production and profit. But in order to assess impacts of hybrid adoption on household living standard we need to go beyond production and profit at the plot level. Technology adoption in one crop may influence other agricultural and nonagricultural activities of the household as well as household consumption (Kristjanson et al., 2012). We measure household living standard in terms of the value of total household consumption per year, including goods and services purchased from the market as well as subsistence consumption. In a linear specification, this consumption value is regressed on the number of acres under hybrid maize as treatment variable. We control for total maize area cultivated, so that the treatment effect can be interpreted on a per-acre basis. To account for differences in household size we control for the number of adult equivalents (AE) living in the household; for living standard assessment, this is more precise than just counting the number of household members independent of their sex and age. Other control variables are size of land owned, non-maize crop revenue, age, and education. The consumption data is from 2009/2010, whereas the independent variables refer to the 2008/2009 season; this reduces potential problems of reverse causality.

The estimation results are shown in Table 3.6. The treatment effect in column 1 is positive but insignificant. Hybrid adoption does not seem to affect household living standards significantly in this specification. In column 2, the north dummy is added, but the treatment 
Table 3.6: Estimated Coefficients of the Household Consumption Model

\begin{tabular}{lccc}
\hline & \multicolumn{2}{c}{ Household consumption in 2009/2010 (1000 TSh/year) } \\
\cline { 2 - 3 } & 1 & 2 & 3 \\
\hline Hybrid maize area (acres) & $41.14(35.21)$ & $56.68(36.52)$ & $104.35^{* *}(45.07)$ \\
Maize area (acres) & $3.32(16.21)$ & $-1.22(16.45)$ & $-1.79(16.42)$ \\
Land owned (acres) & $44.67 * * *(9.44)$ & $42.91^{* * *}(9.50)$ & $41.76^{* * *}(9.50)$ \\
Household size (AE) & $359.56^{* * *}(62.73)$ & $380.84 * * *(64.08)$ & $380.46 * * *(63.98)$ \\
Nonmaize crop revenue (1000 TSh/year) & $-0.00002(0.00005)$ & $-0.00003(0.00005)$ & $-0.0001(0.00005)$ \\
Education of farmer (years) & $76.50^{* * *}(19.75)$ & $75.38^{* * *}(19.74)$ & $71.50^{* * *}(19.83)$ \\
Age of farmer (years) & $2.66(4.25)$ & $2.69(2.25)$ & $2.06(4.25)$ \\
North & & $-202.47(127.94)$ & $-292.02 * *(137.09)$ \\
Hybrid maize area-east interaction & $153.93(299.56)$ & $213.23(295.62)$ & $309.16(299.92)$ \\
Constant & 695 & 695 & 695 \\
Number of observations & 0.12 & 0.12 & 0.13 \\
$\mathrm{R}^{2}$ & & & $-135.11^{*}(75.12)$
\end{tabular}

$*, * *, * * *$, Coefficient is statistically significant at the $10 \%, 5 \%$ and $1 \%$ level, respectively. Coefficient estimates are shown with standard errors in parentheses. The reference region is east. AE, adult equivalent. TSh, Tanzanian Shilling. Source: Author’s estimations.

effect remains insignificant. In column 3, a hybrid adoption and east interaction term is added, which has a negative and significant coefficient. Now the treatment effect increases and turns significant. These results suggest that one acre of hybrid adoption in the north increases household consumption by 104,347 TSh (69 US\$). In the east, no significant consumption effect through hybrid adoption can be observed. A Wald test failed to reject the null hypothesis that the sum of the coefficients on hybrid area and the interaction term is zero.

The coefficient of the north dummy is negative and significant in column 3 , indicating that - holding other factors constant - living standards are lower in the north than in the east. This may be due to less favorable agroecological conditions and differences in cropping patterns. Hybrid adoption can partly compensate for this geographical disadvantage, suggesting that this technology contributes to a reduction in spatial inequality in Tanzania.

We can also use the estimates from column 3 of Table 3.6 to assess the contribution of hybrids to household living standard in the north. The average adopter in the north had 2.63 
acres of maize hybrids. Multiplying the estimated per-acre coefficient from the consumption model with this average hybrid area results in a household-level increase in annual consumption of 274,433 TSh (181 US\$) through hybrid adoption. The average nonadopter in the north had a total annual consumption value of 1,833,783 TSh (1,213 US\$). This means that households in the north increased their average living standard by 15\% through hybrid adoption.

As in the yield model, unobserved differences between adopters and nonadopters could potentially lead to selection bias in the living standard treatment effect estimates. To test and control for such bias we attempted several IV regressions, using the same variables as possible instruments as in the yield model (distance to market and input dealer, low road quality, and religion). But similar to the adoption dummy discussed above, the correlation with the household hybrid maize area was not strong enough to produce reliable estimates. Moreover, infrastructure and religion may influence household consumption directly. As we could not find suitable instruments, we included proxy variables that may be correlated with potentially unobserved factors to test for selection bias, as discussed above. We used the same proxies as for the yield model with the exception of the height-for-age measure. Including a measure of child nutrition as a covariate in a household consumption model would not make sense, as there is an expected causality pointing in the opposite direction. The treatment effects of these auxiliary regressions are shown in the lower part of Table 3.5. These are very similar to the initial treatment effect on living standard in the north (see column 3 of Table 3.6). This is no proof that unobserved heterogeneity is sufficiently captured, but it shows that the results are fairly robust to various specifications.

\subsection{Conclusion}

We have analyzed the impacts of hybrid maize adoption in the small farm sector of Tanzania, building on survey data from two different agroecological zones. In the north, the hybrid adoption rate is $49 \%$, while in the east only $12 \%$ of the sample farmers have adopted hybrid 
seeds. The analysis has shown that hybrid adoption is associated with significant gains in maize yield. Controlling for differences in the use of other inputs, average net yield gains are in a magnitude of $50-60 \%$. Cost increases are only moderate, so that hybrid-adopting farmers realize much higher profits. A geographical disaggregation revealed that the benefits have mostly occurred in the north. Farmers in the east have so far not experienced yield and profit increases, which may explain the lower adoption rates there. Hybrid maize adoption caused a $15 \%$ increase in household living standard in the north, but had no significant impact in the east. It appears that the hybrids available in Tanzania are much better adapted to the agroecological conditions in the north. Since living standards of nonadopting households tend to be somewhat lower in the north than in the east, maize hybrids help to reduce spatial inequality in this particular case.

One limitation of our study is that we could not identify proper instruments for IV estimation. Hence, the treatment effects of hybrids may potentially suffer from selection bias due to unobserved heterogeneity between adopters and nonadopters. However, we ran several auxiliary models with proxies that are likely correlated with relevant unobserved factors. The treatment effects remained robust. We conclude that selection bias - if existent - is unlikely to change the general findings.

All of the maize hybrids that farmers in our sample used were developed by private companies, whereas all improved OPVs were released by the public sector. Therefore, the impacts of hybrid adoption analyzed here can also be interpreted as one implication of seed market liberalization and privatization. Private seed companies were only allowed to enter the market in Tanzania after structural reforms in the early 1990s. Since then, foreign and domestic companies have released an increasing number of maize hybrids. Our results demonstrate that the growing private sector involvement has led to sizeable productivity and welfare gains for smallholder farmers. The findings contradict the notion that improved seeds in general, and proprietary hybrids in particular, would always require higher use of other external inputs. 
Almost none of the maize plots in our sample were irrigated, only very few farmers applied chemical fertilizer or pesticides, and many planted hybrid maize intercropped with legumes. Our results also show that hybrids can still outperform traditional varieties when they are recycled and not freshly purchased every year.

Why suitable hybrids for the eastern zone of Tanzania were not available is not entirely clear. Agroecological differences require adaptation to local conditions. But it is also unclear why half of the maize farmers in the northern zone, to which the available hybrids are well adapted, did not yet adopt in spite of sizeable benefits. Further research is necessary to better understand adoption patterns and constraints. In addition to aspects related to seed market efficiency and access to credit, adoption studies should also consider the role of information flows, learning, social networks, and behavioral biases (Duflo et al., 2008; Foster and Rosenzweig, 1995; Matuschke and Qaim, 2009). Another important facet of further research should be impacts of hybrid adoption on varietal diversity and in situ conservation of genetic resources.

Seed market liberalization and privatization have benefited smallholder maize farmers in Tanzania. However, this does mean that there is no role for the public sector anymore. Many private breeding programs build on germplasm developed in the public sector. Especially with a view to marginal areas, relying on the private sector alone may not suffice to ensure sustainable innovation. Complementarities between private and public breeding efforts should be exploited wherever possible. Moreover, public organizations are vital to undertake efficiency-enhancing functions in seed testing, registration, certification, and in the provision of intellectual property rights. Finally, in some situations there may be a role for governments to stimulate demand for proprietary seeds through targeted subsidies or other interventions. Hence, liberalization and greater participation of the private sector should not imply elimination of public sector programs and regulations. Rather, the focus should be on removing restrictive barriers to market entry. 


\section{Big Constraints or Small Returns? Explaining Nonadoption of Hybrid Maize in Tanzania}

Modern technologies are often not widely adopted among smallholder farmers in Sub-Saharan Africa. Several adoption constraints have been discussed in the literature, including limited access to information. Using survey data from farmers in Tanzania and the average treatment effect framework, we question the hypothesis that limited information is an important constraint for the adoption of hybrid maize technology. While we find an adoption gap from incomplete awareness exposure, this gap is sizeable only in the east of Tanzania, where productivity effects of hybrids are small. In the north, where adoption is much more beneficial, almost all farmers are already aware of hybrids. The results suggest that exposure to a new technology may be a function of expected returns to adoption. We also test for other constraints related to credit and risk, which do not determine adoption significantly. More generally, nonadoption of technologies is not always a sign of constraints but may also indicate low benefits. Some policy implications are discussed.

\subsection{Introduction}

Agricultural technology is a fundamental driving force for rural development. But the adoption of modern technologies, such as improved seeds and fertilizers, is low in many developing countries (Foster and Rosenzweig, 2010). For instance, in developing countries, only around $50 \%$ of the maize area is under modern varieties (MVs), including hybrids and improved open-pollinated varieties (OPVs), whereas in developed countries the MV share is close to $100 \%$. There are also large differences in yield. Mean maize yields are 4 t/ha and 9 t/ha in developing and developed countries, respectively (Shiferaw et al., 2011). 
In Sub-Saharan Africa, the adoption of MVs is still lower than in other developing regions, which cannot be explained by issues of availability alone (Byerlee and Heisey, 1996). The search for reasons has concentrated on several adoption constraints. One such constraint is limited access to information; being aware of a technology is a necessary condition for adoption (Diagne and Demont, 2007). Other possible constraints are market imperfections for insurance and credit (Foster and Rosenzweig, 2010). Policy recommendations usually focus on alleviating such constraints through the provision of extension, insurance, or credit schemes. A recent study has pointed towards behavioral biases as a related but conceptually different set of constraints (Duflo et al., 2011). Farmers may have access to information, credit, and insurance, but fail to behave rationally, for example by discounting myopically. A policy response could be in the form of "nudges" to correct behavioral biases. Yet another possibility is that nonadoption is neither the result of constraints nor behavioral biases. Unconstrained, rational nonadoption of a particular technology would imply that the returns to adoption are negative or insignificant (Suri, 2011). Which of these reasons dominates is an important question for policymaking with a view to facilitating innovation adoption and productivity growth.

In this chapter, we analyze the adoption of hybrid maize technology in Tanzania, testing the different possibilities. Maize is the main staple food in Tanzania and is primarily grown by smallholder farmers. We use survey data from two regions, the north where hybrid adoption rates are relatively high, and the east where adoption is much lower. Specifically, we examine whether low adoption can be explained by lack of awareness exposure, and whether low adoption and lack of exposure may be the result of limited returns. To our knowledge, such a link between information constraints and returns to adoption has never been analyzed in the empirical literature. We use Diagne and Demont's (2007) average treatment effect (ATE) framework to show that lack of awareness of hybrid seeds is not an important constraint to adoption in Tanzania. The adoption gap caused by incomplete awareness is not very 
large. And, assuming full exposure, adoption rates would still differ considerably between the two regions, which we explain by insignificant yield effects of hybrid technology in the east. We also find that the spread of information about hybrids through extension and farmer networks is important in the north but not in the east, suggesting that exposure may actually be a function of expected returns. We do not find evidence for constraints related to risk or credit and conclude that the alleviation of adoption constraints with respect to existing technologies should be carefully balanced with efforts to develop new technologies that are better targeted to diverse local conditions.

\subsection{Background}

There are multiple and sometimes conflicting reasons mentioned for the low adoption rates of MVs in Sub-Saharan Africa. One explanation is that available MVs are not sufficiently adapted to local farmers’ needs (Doss, 2003). Byerlee and Heisey (1996) argue that breeders have paid too little attention to local agroecological conditions, agronomic practices, processing characteristics, and seasonal labor availability. Smale et al. (1995) show for Malawi that many MV adopters continue to use traditional varieties due to consumption preferences and that they allocate less land to MVs with lower market orientation. Feleke and Zegeye (2006) observe for Ethiopia that MV adoption is more likely with higher labor availability. Suri (2011) uses a model that allows for heterogeneity in profitability and finds that many Kenyan farmers did not adopt hybrids because of limited benefits. However, she also shows that $20 \%$ of farmers are nonadopters who could derive high returns from hybrid adoption, suggesting that at least some farmers are constrained in their access to credit and inputs.

Such infrastructure constraints, including poor market integration, communication, and transport, comprise a second cluster of explanatory factors (Chirwa, 2005). Women in particular often face difficulties in accessing inputs that are complementary to MVs (Doss and Morris, 2001). Langyintuo et al. (2010) note that poorer farmers are less likely to adopt mod- 
ern maize varieties due to cash and credit constraints. Smale et al. (1995) confirm that credit club membership increases the likelihood of adoption of MVs and fertilizers.

In contrast, Duflo et al. (2008) maintain that low fertilizer and hybrid seed adoption can be explained by non-fully rational behavior, rather than by low returns or exogenous constraints. Based on randomized controlled trials, they posit that farmers have trouble in learning whether fertilizer recommendations are adapted to their conditions and struggle to save enough money for buying seeds and other inputs in the next planting season. Duflo et al. (2011) suggest that simple interventions (“nudges”), such as improving the information provided by extension agents, could help; they also report that when farmers are offered to buy fertilizer at the end of the previous season, adoption rates increase significantly. Improving extension services could also reduce the apparent lack of farmers' awareness of improved MVs (Langyintuo et al., 2010). Also referring to extension services, Spielman et al. (2010) attribute low adoption levels partly to inflexible one-size-fits-all recommendations.

These different explanations can be categorized as shown in Table 4.1. Farmers can fall into one of four possible categories with respect to MV adoption, depending on the superiority of the new varieties and whether or not they are actually adopted. Each outcome is based on different theoretical lines of reasoning, leading to a specific set of policy interventions to further improve farmers’ welfare.

In the first and best case, adoption of superior MVs is a rational and informed decision that is not constrained by limited access to seed dealers, credit, or other markets. In this case, no policy intervention is needed, except for promoting further improvement of MVs. Second, farmers do not adopt MVs, but would be better off if they did. Depending on the underlying reasons, suggested policy responses would be either investment into better functioning markets or "nudges". Third, due to vested interests or ignorance, seed companies and/or government extension services may delude farmers into adopting inferior varieties that do not benefit them, with farmers having little understanding and control of this process. In that case, biases 
Table 4.1: Adoption Behavior, Impact, Causes, and Remedies

\begin{tabular}{|c|c|c|}
\hline & MVs adopted & MVs not adopted \\
\hline \multirow[t]{2}{*}{$\begin{array}{l}\text { MVs superior to tra- } \\
\text { ditional varieties }\end{array}$} & $\begin{array}{l}\text { 1. Based on experience, or unbiased } \\
\text { information provided by others, farmers } \\
\text { correctly expect that the adoption of } \\
\text { MVs is beneficial. } \\
\text { Remedy: Not needed. Continue promo- }\end{array}$ & $\begin{array}{l}\text { 2(a). Exogenous constraints are the ma- } \\
\text { jor reasons for low adoption, including } \\
\text { information and credit constraints. } \\
\text { Remedy: Invest in better functioning } \\
\text { markets. }\end{array}$ \\
\hline & tion of $M V$ development. & $\begin{array}{l}\text { 2(b). Behavioral biases (e.g., lack of } \\
\text { saving discipline) are the main cause. } \\
\text { Remedy: "Nudges". }\end{array}$ \\
\hline $\begin{array}{l}\text { Traditional varieties } \\
\text { superior to MVs }\end{array}$ & $\begin{array}{l}\text { 3. Farmers are deluded into adopting } \\
\text { MVs that do not benefit them. } \\
\text { Remedy: Improve flow of unbiased in- } \\
\text { formation. Develop varieties better } \\
\text { adapted to farmers' conditions. }\end{array}$ & $\begin{array}{l}\text { 4. Lack of MVs adapted to farmers' } \\
\text { conditions is responsible for low adop- } \\
\text { tion rates. } \\
\text { Remedy: Develop varieties better } \\
\text { adapted to farmers' conditions. }\end{array}$ \\
\hline
\end{tabular}

Source: Author's illustration.

in the information delivered to farmers must be overcome, and new varieties better adapted to local conditions be made available. Fourth, traditional varieties may be superior to MVs for many farmers, but farmers are aware of this fact, which would explain low adoption rates (Suri, 2011). An appropriate policy response would have to focus on promoting the development of varieties that are better adapted to farmers’ conditions.

Several studies have examined information constraints to technology adoption. For example, Matuschke and Qaim (2009) argue that information constraints are one main obstacle to the adoption of hybrid seeds, and that active social networks can reduce such hurdles. Kabunga et al. (2012a, 2012b) have analyzed the adoption of tissue culture (TC) bananas in Kenya, which is a relatively knowledge-intensive technology. While most farmers are aware of this technology, many do not know how to use TC successfully, so that adoption rates remain relatively low. Hence, information constraints play an important role in many contexts, but probably not in all.

Very few studies have estimated the returns to adoption of technologies that are alleged to be underutilized (Foster and Rosenzweig, 2010). A recent exception is Suri (2011), 
who analyzed data on hybrid maize adoption in Kenya and found that a large proportion of nonadoption can be explained by low returns. On the other hand, there are hardly cases of widely adopted technologies that do not deliver some form of benefits to farmers. This is plausible; at least for technologies in annual crops, farmers can observe the performance and update their beliefs and choices for subsequent years accordingly. There is also evidence that the speed of adoption is higher when the benefits are larger. Griliches (1957) showed that differences in diffusion and equilibrium adoption rates of hybrid maize between regions can be explained by differences in profitability. In India, the rapid and widespread adoption of Bt cotton can be explained by large yield and profit gains (Kathage and Qaim, 2012).

Existing empirical studies have considered information constraints and the magnitude of technological benefits as two separate aspects in explaining adoption. This is surprising, because information flows can be a function of adoption returns. Positive impacts of a technology will be advertised by companies with the aim to reach additional customers. Information about successful technologies will also spread through word-of-mouth. For example, Matuschke and Qaim (2008) observed that hybrid adopters with positive experiences are important sources of information for other farmers. Conversely, one can expect that highly negative impacts of a technology will also become a warning to others, while insignificant impacts may not be reported and noticed widely.

\subsection{Analytical Framework}

In order to analyze information constraints to hybrid adoption we use the ATE framework, which goes back to the work of Rubin (1973). It was applied in a technology adoption context by Diagne and Demont (2007), and more recently by Kabunga et al. (2012a). We follow this approach and summarize the relevant details in the following.

Diagne and Demont (2007) demonstrate that the "true" population adoption rate cannot be consistently estimated unless exposure is controlled for. The "true" adoption rate refers 
to a situation of complete exposure to a technology. The adoption rate observed in a sample from a population that is not completely exposed is lower, since at least some of the nonexposed farmers would adopt if they were exposed (Diagne and Demont, 2007). Nor can the true population adoption rate be estimated consistently from the subsample of exposed farmers due to selection bias in exposure. Also the determinants of adoption cannot be estimated consistently, unless they are separated from the determinants of exposure. A farmer cannot decide whether to adopt a technology when not aware of it. For example, if social networks are found to have an impact on adoption, we do not know whether social networks matter for exposure, adoption, or both. But knowing this matters for the design of policy interventions.

The ATE framework is used to separate exposure and adoption and to calculate adoption gaps resulting from incomplete exposure. The two main components of this framework are a binary treatment variable $w$ that refers to exposure status and a binary outcome variable $y$ that refers to adoption status. For each farmer $i$ the treatment effect is defined as the difference of adoption status if exposed and adoption status if not exposed $\left(y_{1 i}-y_{0 i}\right)$. It corresponds to $E\left(y_{1 i}-y_{0 i}\right)$ at the population level, where it is called ATE. $y_{0 i}$ is always equal to zero, since exposure is a necessary condition for adoption. Therefore, $A T E$ reduces to $E\left(y_{1 i}\right)$. For exposed farmers, $y_{1 i}$ is observed and called the average treatment effect on the treated $\left(A T E_{1}\right)$. For nonexposed farmers, $y_{1 i}$ is not observed and called the average treatment effect on the untreated $\left(A T E_{0}\right)$. The observed sample adoption rate is called the joint exposure and adoption rate (JEA), because observed adoption implies exposure. The difference between JEA and ATE is called the adoption gap (GAP). GAP indicates by how much incomplete exposure reduces the adoption rate. The population selection bias (PSB) is defined as the difference between $A T E_{1}$ and ATE and shows the extent of bias in an estimate of the adoption rate under full exposure based on the observed adoption rate among the exposed subsample. 
The challenge of identifying ATE amounts to estimating $\mathrm{y}_{1 i}$ for the nonexposed subsample. The identification of ATE is based on the conditional independence assumption (CI), which states that treatment status $w$ is independent of potential outcome status $y$ conditional on a set of observed covariates $z: P\left(y_{j}=1 \mid w, z\right)=P\left(y_{j}=1 \mid z\right) ; j=0,1$. The ATE estimators based on the CI assumption can be estimated using either parametric or nonparametric regression methods. Following Kabunga et al. (2012a), we employ parametric regression in a model for the conditional expectation of the observed variables $y, x$, and $w$ (for details see Demont and Diagne, 2007):

$$
E(y \mid x, w=1)=g(x, \beta)
$$

where $g$ is a function of observed covariates $x$ determining adoption and a parameter vector $\beta$. The parameter vector $\beta$ can be estimated by maximum likelihood techniques using observations in the exposed subsample with $y$ as dependent and $x$ as independent variables. The estimated parameters $\widehat{\beta}$ are used to predict values for $y$ in the nonexposed subsample. Averages of these predicted values determine $A T E, A T E_{1}$, and $A T E_{0}$, respectively:

$$
\begin{gathered}
\widehat{A T E}=\frac{1}{N} \sum g(x, \widehat{\beta}) \\
\widehat{A T E_{1}}=\frac{1}{N_{\mathrm{e}}} \sum w g(x, \widehat{\beta}) \\
\widehat{A T E}_{0}=\frac{1}{N-N_{\mathrm{e}}} \sum(w-1) g(x, \widehat{\beta}) .
\end{gathered}
$$

Exposure must be controlled for in a first stage because it is not random. This first stage, which estimates the determinants of exposure and predicts propensity scores, predates the ATE estimation. The covariates determining exposure $(z)$ are allowed to differ from the covariates determining adoption (x) (Diagne and Demont, 2007). 


\subsection{Data and Descriptive Statistics}

\subsubsection{Survey}

A household survey was conducted in the eastern and northern zones of Tanzania in late 2010. These two zones represent two main agroecological climates of Tanzania, highlands (north) and lowlands (east). Within these two zones, four districts (Mvomero, Kilosa, Karatu, Mbulu) from three regions (Morogoro, Arusha, Manyara) were deliberately chosen. Then, 30 wards and 60 villages were randomly selected. At the village level, households were sampled randomly, taking district level population sizes into account. In each zone (henceforth "region”) 350 households were selected, resulting in a total sample size of 700 households. Out of these, 695 grew maize.

The head of each household was taken through a structured interview, providing detailed information on household composition, location and infrastructure, social capital, asset ownership, agricultural production, and other economic activities. Agricultural production details refer to the 2008/2009 season. Input and output data for cropping activities were captured for all plots on a farm, so that the number of plot observations is larger than the number of households surveyed. With respect to varietal awareness, each farmer was asked to name the traditional varieties, improved OPVs, and hybrids they were aware of and whether they had adopted them in 2008/2009 or before.

\subsubsection{Descriptive Statistics}

The average farm size in the sample is around 5 acres. This is in line with census data from Tanzania. Of all maize growers, 31\% used maize hybrids at least on a part of their total maize area; 9\% were partial adopters and 21\% were full adopters in 2008/2009. Adoption patterns differ between regions. In the north, partial adoption was observed for $14 \%$ and full adoption for $34 \%$, whereas in the east, partial and full adoption was observed for only $5 \%$ and $8 \%$, respectively. Considering the total maize area of farms, $23 \%$ was cultivated with hybrids. This 
includes recycled hybrids, which were grown on almost one-quarter of the total hybrid area. All hybrids used by sample farmers were of private origin, and all seeds of private origin were hybrids (all improved OPVs were of public origin). In our analysis we focus on hybrids because their release in Tanzania is more recent and their expected yield potential higher than for OPVs. Following seed market liberalization in the early 1990s, over 20 hybrids have been released by several seed companies. In our sample, five hybrids are most commonly used; their relative importance is similar in the north and east.

Descriptive statistics are shown in Tables 4.2 and 4.3. We categorize farmers according to exposure and adoption status and compare several variables of interest. Overall, 430 farmers (62\% of all maize farmers in the sample) have heard about at least one hybrid, meaning that they are exposed to hybrid technology (Table 4.2). We had also asked farmers more generally whether they had received information on new maize varieties before the 2008/2009 season from formal sources, such as government, non-governmental organizations (NGOs), or private companies. ${ }^{9}$ The share is somewhat larger among the exposed farmers.

The distance to the next seed dealer, measured in walking time, is somewhat larger for the exposed farmers, which is surprising. One would have expected the opposite, but distance alone may not be a perfect proxy for access to relevant information. Information flows may also occur through social networks. We use network membership, defined as a dummy that takes a value of one if the farmers is member in any formal or informal association ranging from input or marketing cooperatives to savings and credit groups. Table 4.2 shows that such network membership is higher among the farmers exposed to hybrid maize technology. Exposed farmers also tend to live in larger villages, which is often associated with more social interaction and information exchange (Matuschke and Qaim, 2009). Moreover, we observe a

\footnotetext{
${ }^{9}$ This variable is different from the exposure variable, as new varieties involve both improved OPVs and hybrids. Moreover, farmers may know hybrids without having received this information from formal sources. Fellow farmers are an important source of information in the local context.
} 
Table 4.2: Descriptive Statistics by Exposure Status

\begin{tabular}{lcc}
\hline & Exposed & Nonexposed \\
\hline Information received on new varieties (dummy) & $0.39^{*}(0.49)$ & $0.34(0.47)$ \\
Distance to seed dealer (walking minutes) & $145.05^{* *}(122.72)$ & $128.98(100.67)$ \\
Network member (dummy) & $0.32^{*}(0.47)$ & $0.26(0.44)$ \\
Village size (number of households) & $645.47^{* *}(255.91)$ & $595.11(310.00)$ \\
Cell phone owner (dummy) & $0.44^{*}(0.50)$ & $0.39(0.49)$ \\
Muslim (dummy) & $0.10(0.30)$ & $0.34^{* * *}(0.47)$ \\
Household size (number of members) & $5.77^{* * *}(2.42)$ & $5.24(2.32)$ \\
Land owned (ha) & $5.01(7.20)$ & $5.52(5.75)$ \\
Education of farmer (years) & $5.51^{* * *}(3.14)$ & $4.84(3.27)$ \\
Age of farmer (years) & $43.5(15.09)$ & $47.58^{* * *}(14.36)$ \\
Maize experience of farmer (years) & $18.82(12.31)$ & $21.06^{* *}(15.33)$ \\
Male household head (dummy) & $0.83^{* * *}(0.38)$ & $0.73(0.44)$ \\
North (dummy) & $0.69^{* * *}(0.46)$ & $0.18(0.39)$ \\
Number of households & 430 & 265 \\
\hline$* * * * * *$ imply that the mean value is significantly higher than that of exposed/nonexposed at the $10 \%, 5 \%$ and
\end{tabular}
$1 \%$ level, respectively. Mean values are shown with standard deviations in parentheses. Source: Author's calculations.

positive correlation between exposure and ownership of a cell phone (land lines are almost nonexistent in the study regions). In terms of land holdings, there are no significant differences between the two groups, but we do observe differences for farmer education, age, gender, and household size. Finally, the comparisons in Table 4.2 reveal significant regional differences in exposure: $69 \%$ of all exposed farmers are located in the north, $82 \%$ of all nonexposed farmers are located in the east.

Table 4.3 compares adopters and nonadopters of hybrid technology. It only considers the 430 exposed farmers, as exposure is a necessary condition for adoption. About half of these exposed farmers are hybrid adopters, suggesting that awareness alone is not a binding constraint to adoption for many farmers. The comparison reveals differences that are similar to those between the exposed and nonexposed farmers. Adopters are more likely to have received information on new varieties, be network members, live in larger villages, own a cell phone, live in larger households, and have more education. Among the exposed, $80 \%$ of 
Table 4.3: Descriptive Statistics by Adoption Status among Exposed

\begin{tabular}{lcc}
\hline & Adopter & Nonadopter \\
\hline Information received on new varieties (dummy) & $0.44^{* *}(0.50)$ & $0.34(0.47)$ \\
Distance to seed dealer (walking minutes) & $136.41(102.57)$ & $153.60^{*}(139.57)$ \\
Network member (dummy) & $0.36^{* *}(0.48)$ & $0.27(0.45)$ \\
Village size (number of households) & $668.09^{* *}(248.71)$ & $623.06(261.49)$ \\
Cell phone owner (dummy) & $0.51^{* * *}(0.50)$ & $0.38(0.49)$ \\
Muslim (dummy) & $0.06(0.23)$ & $0.14^{* * *}(0.35)$ \\
Household size (number of members) & $6.01^{* *}(2.44)$ & $5.52(2.38)$ \\
Land owned (ha) & $4.65(5.04)$ & $5.37(8.85)$ \\
Education of farmer (years) & $5.78^{* *}(3.16)$ & $5.24(3.11)$ \\
Age of farmer (years) & $44.32(13.91)$ & $42.68(16.17)$ \\
Maize experience (years) & $19.25(11.96)$ & $18.40(12.67)$ \\
Male household head (dummy) & $0.79(0.41)$ & $0.86^{* *}(0.35)$ \\
North (dummy) & $0.80^{* * *}(0.40)$ & $0.59(0.49)$ \\
Credit constraint (share) & $0.23(0.42)$ & $0.21(0.41)$ \\
Number of households & 214 & 216
\end{tabular}

*, **, *** imply that the mean value is significantly higher than that of adopter/nonadopter. Mean values are shown with standard deviations in parentheses. Source: Author's calculations.

adopters and $59 \%$ of nonadopters are located in the north.

Unlike for exposure, nonadoption is positively correlated with distance to the nearest seed dealer, which one might explain by higher transportation costs to obtain seed and related inputs. However, seed is typically purchased in small quantities only once per season and the use of inputs such as fertilizer and pesticides is rare in our sample. Therefore, distance to seed dealer may not be a constraint to adoption as such but a correlate of more relevant variables. The size of landholdings is not significantly different between adopters and nonadopters. Hence, asset ownership does not seem to drive adoption, and also risk may not be a major determinant (land assets provide insurance). Likewise, there is no difference in the share of farmers that were credit constrained, defined as an unmet need for credit to buy seeds.

In summary, exposed and adopting farmers tend to have more access to information, as measured by several variables related to social networks and communication. At the same time, asset ownership, risk, and access to credit do not play important roles. Against this 
background one could believe that nonadoption is mainly driven by information constraints, which seem to be more severe in the east. Based on this belief, policies targeted to help farmers would focus on spreading awareness. In the next section, we will examine these relationships more closely using the ATE framework explained earlier.

\subsection{Results}

We want to know whether limited information is an important constraint to hybrid adoption in Tanzania. In other words, we ask whether lack of awareness of hybrids is the major reason for many farmers not to adopt. We use the ATE framework to: (1) examine the role of several factors in determining exposure and adoption; and (2) predict adoption rates under complete exposure. We use the variables described in the previous section as covariates in the regression models. Credit constraint is only used in the adoption model, because it is unlikely to influence exposure.

\subsubsection{Determinants of Exposure and Adoption}

Table 4.4 shows the estimated coefficients for the exposure and exposure-corrected adoption models. Strikingly, none of the variables related to information, communication, and social networks has a significant effect on either exposure or adoption. Characteristics of the household head are also insignificant with respect to exposure and adoption, with the exception of gender. Being male increases the likelihood of exposure but reduces the likelihood of adoption. This is similar to results by Kabunga et al. (2012a) who found that female farmers are more likely to adopt when disadvantages in information access are controlled for. The common understanding is that women are less likely to adopt new technologies (Doss and Morris, 2001), but this understanding is based on research that does not differentiate between exposure and adoption.

The contextual variables are also insignificant, except for the district dummies. The 
Table 4.4: Determinants of Exposure and Exposure-corrected Adoption

\begin{tabular}{|c|c|c|}
\hline & Exposure & Adoption \\
\hline Information received on new varieties (dummy) & $0.07(0.12)$ & $0.10(0.14)$ \\
\hline Distance to seed dealer (walking minutes) & $0.001(0.0005)$ & $-0.001(0.001)$ \\
\hline Network member (dummy) & $0.16(0.13)$ & $0.03(0.14)$ \\
\hline Cell phone owner (dummy) & $0.01(0.12)$ & $0.23(0.14)$ \\
\hline Village size (number of households) & $0.0002(0.0002)$ & $-0.0002(0.0003)$ \\
\hline Muslim (dummy) & $-0.24(0.15)$ & $-0.37(0.26)$ \\
\hline Household size (number of members) & $-0.01(0.03)$ & $0.01(0.03)$ \\
\hline Land owned (ha) & $0.002(0.01)$ & $0.01(0.01)$ \\
\hline Education of farmer (years) & $0.03(0.02)$ & $0.02(0.02)$ \\
\hline Age of farmer (years) & $-0.03(0.03)$ & $0.01(0.01)$ \\
\hline Age squared & $0.0002(0.0003)$ & $-0.0001(0.0001)$ \\
\hline Male household head (dummy) & $0.32 * *(0.14)$ & $-0.37 * *(0.18)$ \\
\hline Maize experience (years) & $-0.001(0.01)$ & $-0.001(0.02)$ \\
\hline Maize experience squared & $-0.0001(0.0002)$ & $-0.0001(0.0004)$ \\
\hline Credit constraint (dummy) & & $0.01(0.16)$ \\
\hline Mbulu (dummy) & $0.58 * * *(0.20)$ & $-0.56 * * *(0.18)$ \\
\hline Mvomero (dummy) & $-1.17 * * *(0.19)$ & $-0.70 * *(0.28)$ \\
\hline Kilosa (dummy) & $-1.11^{* * *}(0.16)$ & $-0.97 * * *(0.21)$ \\
\hline Number of observations & 695 & 430 \\
\hline Pseudo $\mathrm{R}^{2}$ & 0.25 & 0.10 \\
\hline LR chi ${ }^{2}\left(\right.$ prob $>$ chi $\left.^{2}\right)$ & $235.10^{* * *}$ & $57.64 * * *$ \\
\hline Log likelihood & -344.41 & -269.23 \\
\hline
\end{tabular}

**, ***, Coefficient is statistically significant at the $5 \%$ and $1 \%$ level, respectively. Coefficient estimates are shown with standard errors in parentheses. The reference district is Karatu. Source: Author's estimations.

reference district is Karatu, which is located in the north. Mbulu farmers are more likely to be exposed but less likely to adopt. For eastern farmers in Mvomero and Kilosa the likelihood of exposure and adoption is strongly reduced. Hybrids are much more widespread in the north than in the east, the question is why?

We can gain further insights by estimating the determinants separately for north and east (Table 4.5). In the exposure model for the north, several variables now turn significant: information received on new varieties from formal sources, network membership, and village size increase the likelihood of exposure (column 1). This suggests that information about hy- 
Table 4.5: Determinants of Exposure and Exposure-corrected Adoption, by Region

\begin{tabular}{|c|c|c|c|c|}
\hline & \multicolumn{2}{|c|}{ North } & \multicolumn{2}{|c|}{ East } \\
\hline & 1 & 2 & 3 & 4 \\
\hline & Exposure & Adoption & Exposure & Adoption \\
\hline $\begin{array}{l}\text { Information received on } \\
\text { new varieties }\end{array}$ & $0.58^{* * *}(0.21)$ & $0.14(0.16)$ & $-0.21(0.16)$ & $0.08(0.30)$ \\
\hline Distance to seed dealer & $0.001(0.001)$ & $-0.0003(0.001)$ & $0.001(0.001)$ & $-0.002(0.002)$ \\
\hline Network member & $0.43 *(0.23)$ & $0.13(0.17)$ & $0.08(0.18)$ & $-0.28(0.31)$ \\
\hline Cell phone owner & $-0.22(0.22)$ & $0.28(0.17)$ & $0.09(0.16)$ & $0.29(0.29)$ \\
\hline Village size & $0.001 *(0.0004)$ & $0.0001(0.0004)$ & $0.0001(0.0002)$ & $-0.0004(0.0004)$ \\
\hline Muslim & $-0.56(0.71)$ & & $-0.23(0.16)$ & $-0.63 * *(0.30)$ \\
\hline Household size & $0.03(0.04)$ & $-0.03(0.03)$ & $-0.06 *(0.04)$ & $0.09(0.07)$ \\
\hline Land owned & $0.04(0.03)$ & $0.01(0.02)$ & $-0.02(0.02)$ & $-0.01(0.03)$ \\
\hline Education of farmer & $0.03(0.03)$ & $0.06 * *(0.03)$ & $0.03(0.03)$ & $-0.06(0.05)$ \\
\hline Age of farmer & $-0.01(0.01)$ & $0.01(0.01)$ & $-0.07 *(0.04)$ & $0.05(0.07)$ \\
\hline Age squared & $0.00001(0.0001)$ & $-0.000001(0.0001)$ & $0.001(0.0004)$ & $-0.001(0.001)$ \\
\hline Male household head & $0.61^{* *}(0.22)$ & $-0.26(0.22)$ & $0.25(0.18)$ & $-0.71 * *(0.33)$ \\
\hline $\begin{array}{l}\text { Maize experience of } \\
\text { farmer }\end{array}$ & $-0.03(0.03)$ & $0.04(0.02)$ & $0.03(0.03)$ & $-0.12 * *(0.05)$ \\
\hline $\begin{array}{l}\text { Maize experience } \\
\text { squared }\end{array}$ & $0.0004(0.0005)$ & $-0.001 *(0.0004)$ & $-0.001(0.001)$ & $0.003 * *(0.001)$ \\
\hline Credit constraint & & $-0.14(0.19)$ & & $0.24(0.32)$ \\
\hline Mbulu / Mvomero & $0.77 * * *(0.25)$ & $-0.40 * *(0.20)$ & $0.05(0.16)$ & $-0.47(0.30)$ \\
\hline Number of observations & 345 & 295 & 348 & 132 \\
\hline Pseudo $\mathrm{R}^{2}$ & 0.18 & 0.09 & 0.06 & 0.12 \\
\hline LR chi ${ }^{2}\left(\right.$ prob $>$ chi $\left.^{2}\right)$ & $50.70 * * *$ & $36.60 * * *$ & $27.90^{* *}$ & 20.42 \\
\hline Log likelihood & -113.82 & -183.32 & -217.03 & -73.10 \\
\hline
\end{tabular}

*, **, ***, Coefficient is statistically significant at the $10 \%, 5 \%$, and $1 \%$ level, respectively. Coefficient estimates are shown with standard errors in parentheses. The variable Muslim had to be excluded in column 2 because there are only two exposed Muslim farmers in the sample who are both adopters. Mbulu refers to columns 1 and 2, the reference district is Karatu. Mvomero refers to columns 3 and 4, the reference district is Kilosa. Source: Author's estimations.

brids spreads through formal channels (external agents) and social networks within villages. In the exposure model for the east, we see that the same three variables are not significant (column 3). If farmers receive information on new varieties through formal sources, they are not more likely to become aware of hybrids, possibly because these external agents focus on OPVs. The insignificance of the other two variables suggests that farmer-to-farmer infor- 
mation transfer does not increase awareness of hybrids either. If some farmers know or have experimented with hybrids without realizing clear benefits, they may not further disseminate that awareness in the village and in farmer groups. This is consistent with the idea that returns to adoption are significant in the north and insignificant in the east, an issue we will inspect further below.

In the regional adoption models, a few variables also turn significant, but mostly with different effects in north and east (columns 2 and 4). In the north, education increases the likelihood of adoption, while the same effect is not observed in the east. Experience in maize cultivation and male household head decrease the likelihood of adoption in the east, while these effects are not observed in the north. Muslim also has a large negative effect on adoption in the east, possibly due to unobserved cultural or economic correlates of religion. These patterns are consistent with potential differences in returns to adoption. For example, it is often observed that experience positively predicts adoption, but in our case the opposite is true in the east. If returns to hybrid adoption are low in the east, more experienced farmers may be better equipped to make the right decision not to adopt. Finally, two other variables deserve attention. Land holdings and credit constraints are not significant in any of the models, despite the fact that hybrid seeds are more costly than OPVs. Hence, nonadoption is unlikely to be the result of market failures relating to credit or insurance.

\subsubsection{Predicted Adoption Rates under Full Exposure}

We use the ATE estimates to predict adoption rates with and without information constraints for the total sample and separately by region. The results are shown in Table 4.6. The lower part of the table shows the actually observed exposure and adoption rates. The upper part shows predicted adoption rates when complete exposure is assumed. JEA is identical to the observed adoption rate, while $A T E_{1}$ is identical to the observed adoption rate among the exposed farmers. Of particular interest is ATE, which is the predicted adoption rate with com- 
Table 4.6: Predicted Adoption Rates

\begin{tabular}{|c|c|c|c|}
\hline & Total & North & East \\
\hline \multicolumn{4}{|l|}{ ATE-corrected population estimates } \\
\hline Predicted adoption rate in the full population (ATE) & $0.45^{* * *}(0.02)$ & $0.57 * * *(0.03)$ & $0.35 * * *(0.04)$ \\
\hline $\begin{array}{l}\text { Predicted adoption rate in exposed subpopulation } \\
\left(A T E_{1}\right)\end{array}$ & $0.50 * * *(0.02)$ & $0.57 * * *(0.03)$ & $0.33 * * *(0.04)$ \\
\hline $\begin{array}{l}\text { Predicted adoption rate in nonexposed subpopulation } \\
\left(A T E_{0}\right)\end{array}$ & $0.38 * * *(0.04)$ & $0.60 * * *(0.04)$ & $0.37 * * *(0.04)$ \\
\hline Joint exposure and adoption rate (JEA) & $0.31 * * *(0.01)$ & $0.49 * * *(0.02)$ & $0.12 * * *(0.01)$ \\
\hline Population adoption gap (GAP) & $-0.14 * * *(0.01)$ & $-0.08 * * *(0.01)$ & $-0.23 * * *(0.03)$ \\
\hline Population selection bias (PSB) & $0.04 * * *(0.01)$ & $-0.004(0.004)$ & $-0.03 *(0.02)$ \\
\hline \multicolumn{4}{|l|}{ Observed sample estimates } \\
\hline Exposure rate $\left(N_{\mathrm{e}} / N\right)$ & $0.62 * * *(0.02)$ & $0.86 * * *(0.02)$ & $0.38 * * *(0.03)$ \\
\hline Adoption rate $\left.\left(N_{\mathrm{a}} / N\right)\right)$ & $0.31 * * *(0.02)$ & $0.49 * * *(0.03)$ & $0.12 * * *(0.02)$ \\
\hline Adoption rate among the exposed subsample $\left(N_{\mathrm{a}} / N_{\mathrm{e}}\right)$ & $0.50 * * *(0.03)$ & $0.57 * * *(0.03)$ & $0.33 * * *(0.05)$ \\
\hline
\end{tabular}

*, ***, Estimate is statistically significant at the $10 \%$ and $1 \%$ level, respectively. Estimates are shown with standard errors in parentheses. Source: Author’s estimations.

plete exposure. ATE for the total sample is $45 \%$, which is 14 percentage points higher than the actual adoption rate of $31 \%$. These 14 percentage points are explicitly stated in the GAP.

Looking at the two regions separately, the adoption gap in the north is -0.08 . Hence, hybrid adoption would increase from $49 \%$ to $57 \%$ if all farmers were exposed instead of the observed 86\% exposure rate. This increase in adoption through lifting information constraints is not very large; the reason is that awareness in the north is already widespread. Nevertheless, more than half of the nonexposed farmers in the north would adopt if they were exposed. In the east, the adoption gap due to information constraints is -0.23 , suggesting that the adoption rate would increase from $12 \%$ to $35 \%$ with full exposure. This increase is larger than in the north, because awareness about hybrids is less widespread in the east. On the other hand, only one-third of the nonexposed farmers in the east would adopt if they were exposed.

The welfare impacts of closing the adoption gap are not necessarily positive for all farmers. Using the same data from maize farmers in Tanzania, Kathage et al. (2012) showed that hybrids are much higher yielding than nonhybrids in the north, but that there are no sig- 
nificant yield differences in the east. Kathage et al. (2012) also estimated yield models for all maize plots cultivated by sample farmers, controlling for other inputs as well as plot and household characteristics. Results from their main model are summarized in Table 4.7; they confirm that the net hybrid yield impact is large and significant in the north but not in the east. These differences are probably due to heterogeneous agroecological conditions, for which the region dummies are proxies. The range of available hybrids is similar in both regions, but these hybrids are better suited to the highland conditions in the north. Under these conditions in the north, increased exposure and adoption may improve farmers' welfare. However, in the east, an increase in exposure and adoption is unlikely to improve welfare significantly. Efforts to improve access to information and increase awareness of existing hybrids may represent a waste of resources there.

Table 4.7: Yield Impact of Hybrid Maize

\begin{tabular}{lc}
\hline & Maize yield in 2008/2009 (kg/acre) \\
\hline Hybrid (dummy) & $0.56 * * *(0.12)$ \\
Hybrid-east interaction & $-0.50^{* * *}(0.22)$ \\
Number of observations & 1117
\end{tabular}

***, Coefficient is statistically significant at the $1 \%$ level. Coefficient estimates are shown with standard errors in parentheses. Cobb-Douglas functional form. Covariates not shown for brevity. Source: Kathage et al. (2012).

\subsection{Conclusions}

We have examined whether information is an important constraint to hybrid maize adoption in Tanzania, or what other factors could explain the relatively low adoption rates. Using the average treatment effect framework and primary survey data from two regions, we found that variables related to information and communication do not significantly influence technology awareness or adoption in the aggregate model. The regionally disaggregated models showed that some of these variables were significant in the north, where returns to adoption are large, 
but most of the farmers in the north are already aware of hybrid technology. The adoption gap due to information constraints is small for the north and larger for the east. However, hybrids do hardly increase yields in the east.

Limited information is not the only possible constraint to technology adoption. Lack of access to credit and insurance against risk are often mentioned as other factors (Foster and Rosenzweig, 2010). Moreover, low availability of seeds in remote areas can play a role, when infrastructure conditions are poor. All these factors can contribute to adoption gaps in general, but in our data they do not seem to explain the low hybrid adoption rates in the east. Neither information related factors nor variables measuring asset ownership and credit constraints were significant in the east. Even if we did not measure all factors very precisely, the main conclusion seems robust: limited awareness exposure is not the root cause of low adoption; rather differences in returns may explain why both exposure and adoption are much lower in the east than in the north.

Our results imply that, especially when adoption and exposure rates are low, one should not automatically infer that constraints are preventing farmers from adopting useful technologies. This finding has some policy implications. As development budgets are limited, investment options should be scrutinized in terms of their efficiency in achieving stated goals. If the goal is increasing smallholder productivity, resources must be allocated between improving access to existing technologies and creating new technologies. One set of constraints relates to imperfect information. Farmers may simply not be aware of existing technologies and their benefits, so that they do not adopt. However, in some situations low exposure and adoption could also be explained by low returns. In that case, efforts to improve awareness and remove other (nonbinding) constraints are misguided and might even be harmful if the net benefits of a technology are negative. For hybrid maize in Tanzania, we have shown that raising awareness exposure could increase adoption somewhat, yet without improving productivi- 
ty for many farmers. Therefore, money would be more wisely spent on developing seeds better suited to diverse local conditions.

To draw some broader lessons about the role of information for adoption, it is useful to differentiate between different types of technologies. Improved crop varieties are often relatively easy to use, without the need for much site-specific experimentation and adaptation by farmers. For such easy-to-use technologies, information spreads relatively fast when these technologies are beneficial. Hence, awareness exposure is positively correlated with benefit potential. In that case, an adoption gap may not primarily require improvements in information flows. This can be different for more knowledge-intensive technologies that require site-specific adaptation, as holds true for many natural resource management technologies (Noltze et al., 2012). In such cases, a farmer-to-farmer transfer of information is less straightforward, and being aware of a technology alone may not suffice for successful adoption. For knowledge-intensive technologies, it may be useful to differentiate between awareness exposure and knowledge exposure, as was done by Kabunga et al. (2012a). An adoption gap due to limited knowledge exposure may require improvements in information flows, for instance through more effective extension services. 


\section{Conclusion}

\subsection{Main Findings}

In the 1980s, many developing countries began to liberalize their seed markets, reducing barriers to entry and other restrictions of private firms. Consequently, domestic as well as foreign enterprises increased their investments to take advantage of new opportunities in these markets. These investments have led to a higher prevalence of proprietary seed technologies. One question of considerable debate in the scientific and political communities is whether smallholder farmers can benefit or are worse off as a result. The research conducted for this dissertation was aimed at evaluating the impacts and adoption of proprietary seed technologies on smallholder farmers. Bt cotton in India and hybrid maize in Tanzania served as two relevant case studies.

In India, liberalization policies have allowed foreign investment by Monsanto, one of the world's leading agricultural biotechnology companies. In a joint venture with Mahyco Company of India, Monsanto introduced the Bt technology to India and released the first $\mathrm{Bt}$ cotton hybrids to farmers in 2002. In the following years, dozens of domestic and multinational seed firms sublicensed the Bt technology to incorporate it into their own breeding programs. Meanwhile the adoption rate of Bt soared. By 2011 about 90\% of the Indian cotton acreage was under Bt, grown by millions of farmers. Bt cotton produces toxins that kill a number of important insect pests known as bollworms when they feed on the plant. Bt can therefore reduce the application of insecticides, but it can also increase effective yield if it prevents more pest damage than insecticides. Through savings in pesticide cost and higher revenue, Bt can increase farm income, but if Bt seed prices are high and yield effects low or negative, this might not hold. 
The agronomic and economic impacts of Bt have been studied extensively, but gaps remained, including selection bias, impact dynamics and consequences beyond the plot level. Our analysis of panel data covering 2002-2008 allowed us to control for selection bias through fixed-effects estimation techniques and also assess the development of impacts over time. In addition to yield impact we also estimated the effects of Bt on profit and household living standard. The main findings are that Bt raised yield by $24 \%$ and profit by $50 \%$ in $2002-$ 2008, and household living standard by $18 \%$ in 2006-2008. These are conservative estimates, as there are indications that yield and profit effects of Bt increased over time, a result of the wider availability of Bt hybrids with improved germplasm. Furthermore, insecticide use on Bt and conventional cotton plots decreased over time, most likely to be explained by large-scale suppression of bollworm populations by Bt.

In Tanzania, seed market liberalization has led to the entry of several foreign firms since the early 1990s. These new entrants focused on hybrid maize, because hybrids are more frequently purchased than nonhybrids. In general, hybrids can confer yield advantages due to the heterosis effect, thereby increasing revenue and farm income. However, hybrid seeds are usually more expensive than nonhybrids, making the question of additional profit an empirical one. Importantly, the yield effect does not only depend on the heterosis effect but also on germplasm quality. A hybrid with poor germplasm may yield less than a nonhybrid with good germplasm.

The impact of hybrid maize in Tanzania has not been scrutinized, which provided the motivation for our study. Based on econometric analysis of cross-sectional household survey data from the north and east of the country, we found that hybrids increased yield by $50-60 \%$ in 2008/2009, which translated into higher profit among hybrid adopters. However, the benefits mostly occurred in the north, where hybrids also caused a 15\% increase in household living standard. In the east, hybrids neither increased yield nor profit and living standard. However, the vast majority of hybrid adopters are located in the north, so that most adopters bene- 
fit from the technology. Another important finding of the study is that the yield impact of hybrids is not reliant upon other external inputs — the use of fertilizer, irrigation or pesticides is very low, and there is no evidence for interaction effects. Nor does the common practice of intercropping alter the hybrid impact. This suggests that hybrid maize is a flexible tool that is not contingent upon (packages of) inputs or agronomic practices.

The adoption rate of hybrid maize in Tanzania is low, just as it is for other improved seed technologies in developing countries. There are multiple explanations circulating in the literature, which can be categorized according to adoption status and benefits from adoption: In the best case, MVs are economically superior to traditional varieties, and farmers adopt them. Second, MVs could be performing worse than traditional varieties, but they are still adopted by farmers, maybe because of biased information or perception. The third possibility is that MVs are better than traditional varieties, but farmers do not adopt them. This is the scenario most often assumed, leading to the conclusion that nonadopters are constrained and that policy should focus on alleviating these constraints. The final possibility is that MVs are not better than traditional varieties, and farmers do not adopt them. In that case, the problem lies with the technology, not with constrained farmers.

In our sample, $31 \%$ of farmers use hybrids. In the north, most farmers are aware of hybrids and $49 \%$ are adopters. In the east, adoption is at $12 \%$ and exposure at $50 \%$. Since awareness about hybrids is a necessary condition for adoption, we asked to what extent lack of awareness can explain nonadoption. Applying the ATE framework, we estimated that closure of the exposure gap would increase the overall adoption rate to $45 \%$. However, most new adopters would be in the east, where the yield and profit impact of hybrids is small. In the north, where adoption is beneficial, almost all farmers are already aware of hybrids. We also observed that the spread of information about hybrids through extension and farmer networks is significant in the north but not in the east and therefore may be driven by returns. Meanwhile we found no evidence that risk or lack of credit constrain adoption. Thus, our results 
imply that nonadoption of hybrid maize in Tanzania is better explained by low returns to this technology rather than constraints.

\subsection{Policy Implications}

The two main findings of this dissertation with relevance for policy making are that the private sector can help deliver improved seed technologies to smallholder farmers in developing countries and that improved seed technologies, including genetically modified crops, can benefit these farmers. In addition, our research suggests new ways of thinking about and dealing with nonadoption.

Seed market liberalization describes the reduction or removal of legal barriers to entry and other significant restrictions of market interactions. Therefore, it allows potential gains from such interactions to be realized. In our case studies, liberalization attracted foreign seed firms to supply new seed technologies to farmers. Most Indian cotton farmers have by now adopted Bt and realized significant gains from it. In Tanzania, a significant minority of farmers adopted and overwhelmingly benefited from hybrid maize, while the nonadopters remained unaffected. Most adoption decisions seem to rest upon what can be described as rational calculation. Thus, liberalization caused much more good than harm for smallholder farmers in these countries. Based on these results, liberalization of seed markets should be promoted in developing countries.

Our results also have implications for policies directly concerned with technology, especially GM technology. Regulations that impede the availability of seed technologies must consider the potential benefits these technologies offer to farmers. There is also room for positive policies regarding seed technologies. The examples of the Green Revolution and Chinese agricultural research, which has developed many GM applications, have demonstrated that profit-oriented business is not necessary for the creation and delivery of improved technologies. Also, private firms are likely to focus primarily on a subset of crops, including those for 
which hybridization is feasible or for which legal IPR are available. Donors and governments could also target the improvement of crops with limited markets, or use prizes to incentivize private firms to aim for this. Furthermore, proprietary seed technologies are built upon basic research, which is a public good that requires philanthropic or public investments.

Finally, our research suggests alternative ways to deal with nonadoption. Donor and government activities that are focused on alleviating constraints might possibly be better redirected towards enabling technology improvements, taking into account the various entry points described above. Adoption decisions seem to be largely unconstrained and information seems to flow efficiently according to the benefits technologies offer. Nonadoption of agricultural technologies in developing countries is not necessarily a sign of constraints or irrationality but may indicate low benefits. This observation is especially relevant for relatively simple technologies (e.g. improved seeds). For more knowledge-intensive technologies (e.g. agronomic practices), farmer-to-farmer transfer of information may be less straightforward and awareness of a beneficial technology not sufficient for its adoption. In any case, there are always farmers that are constrained in their access to beneficial technology in some way, but their number may be much smaller than the number of nonadopters. This strengthens the general recommendation that the rates of return to extension, credit and insurance subsidies should be weighed against the returns to R\&D investments. Similarly, it is not at all clear that cost-effective poverty reduction strategies should focus on spreading existing technologies rather than creating improved technologies.

\subsection{Limitations and Possible Directions for Further Research}

Our research leaves a number of questions unanswered and open to further inquiry, some of which we highlight here. With respect to the impact of Bt cotton in India, our analysis does not shed light on developments since 2008. On the one hand, it is possible that bollworms become resistant to Bt, which would lower the benefits of the technology. Similarly, the inci- 
dence of secondary pests may increase over time. On the other hand, the incorporation of new Bt genes may help delay resistance developments and target a broader pest spectrum.

Regarding the impact assessment of hybrid maize in Tanzania, we could not fully control for potential selection bias based on unobservables. In principle, there are multiple ways of reducing bias, including controlled and natural experiments which are either expensive or dependent on fortunate circumstances. The use of IV in one form or another, and the application of fixed effects models in panel data are two other available strategies. Valid instruments are often hard to find, as we observed in our study. On the other hand, fixed-effects models are easy to implement once panel data are available. In the Bt cotton study, panel data proved especially useful for addressing selection bias. It is therefore recommended that researchers seek to build panel data sets for impact assessment. Panel data could also help examine adoption dynamics, as well as flows of information, which is difficult with cross-sectional data. More research is also needed to further explore the relationship of benefits and information flows. Under what conditions and for what types of technologies is low adoption a sign of low benefits?

There are also more general questions emerging from our research. We have shown that liberalization has been conducive to productivity growth in India and Tanzania. However, the share of Indian farmers that have benefited from Bt cotton is much larger than the share of Tanzanian farmers that have benefited from hybrid maize. If the reason lies in the different natures of the technologies, then why is Bt cotton or Bt maize not yet available in Tanzania? If the reason lies in different market structures, then why have hybrids suitable for eastern Tanzania not been developed? How government policies can shape liberalization and privatization for the benefit of smallholder farmers is an important question for further research. For instance, a better understanding of information and knowledge flows among farmers, as well as between farmers and private seed firms, is needed in order to better understand the potential contribution of government extension services. 
We have considered seed market liberalization only from the perspective of farmers. Liberalization might also have other important impacts. Do domestic seed producers lose out in the competition with new entrants, or might they benefit through learning effects? To what extent do consumers profit from increases in farm productivity brought about by proprietary seed technologies? Do imports of modern seed technologies reduce or increase crop genetic diversity in farmers' fields? In order to evaluate seed market liberalization in a more comprehensive manner, these questions should be approached in future research. 


\section{Bibliography}

Ali, A., Abdulai, A., 2010. The adoption of genetically modified cotton and poverty reduction in Pakistan. Journal of Agricultural Economics 61, 175-192.

Amare, M., Asfaw, S., Shiferaw, B., 2012. Welfare impacts of maize-pigeonpea intensification in Tanzania. Agricultural Economics 43, 27-43.

Areal, F.J., Riesgo, L., Rodríguez-Cerezo, E., 2013. Economic and agronomic impact of commercialized GM crops: A meta-analysis. The Journal of Agricultural Science 151, 27-43.

Baltagi, B., Song, S., 2006. Unbalanced panel data: A survey. Statistical Papers 47, 493-523.

Barrett, C.B., Moser, C.M., McHugh, O.V., Barison, J., 2004. Better technology, better plots, or better farmers? Identifying changes in productivity and risk among Malagasy rice farmers. American Journal of Agricultural Economics 86, 869-888.

Battese, G.E., 1997. A note on the estimation of Cobb-Douglas production functions when some explanatory variables have zero values. Journal of Agricultural Economics 48, $250-252$.

Bennett R., Ismael Y., Kambhampati U., Morse S., 2004. Economic impact of genetically modified cotton in India. AgBioForum 7, 96-100.

Bennett, R., Ismael, Y., Morse, S., 2005. Explaining contradictory evidence regarding impacts of genetically modified crops in developing countries. Varietal performance of transgenic cotton in India. Journal of Agricultural Science 143, 35-41.

Bennett, R., Kambhampati, U., Morse, S., Ismael, Y., 2006. Farm-level economic performance of genetically modified cotton in Maharashtra, India. Review of Agricultural Economics 28, 59-71.

Byerlee, D., 1996. Modern varieties, productivity, and sustainability: Recent experience and emerging challenges. World Development 24, 697-718. 
Byerlee, D., Heisey, P., 1996. Past and potential impacts of maize research in sub-Saharan Africa: A critical assessment. Food Policy 21, 255-277.

Carpenter, J., 2010. Peer-reviewed surveys indicate positive impact of commercialized GM crops. Nature Biotechnology 28, 319-321.

Chahal, G.S., Gosal, S.S., 2002. Principles and procedures of plant breeding. Pangbourne: Alpha Science International.

Chirwa, E., 2005. Adoption of fertiliser and hybrid seeds by smallholder maize farmers in Southern Malawi. Development Southern Africa 22, 1-12.

Choudhary, B., Laroia, G., 2001. Technological developments and cotton production in India and China. Current Science 80, 925-932.

Cooksey, B., 2011. Marketing reform? The rise and fall of agricultural liberalisation in Tanzania. Development Policy Review 29, s57-s81.

Crost, B., Shankar, B., Bennett, R., Morse, S., 2007. Bias from farmer self-selection in genetically modified crop productivity estimates: Evidence from Indian data. Journal of Agricultural Economics 58, 24-36.

Deaton, A., 1997. The analysis of household surveys: A microeconometric approach to development policy. Baltimore: Johns Hopkins University Press for the World Bank.

Deaton, A., 2010. Instruments, randomization, and learning about development. Journal of Economic Literature 48, 424-455.

De Groote, H., Doss, C., Lyimo, S., Mwangi, W., 2002. Adoption of maize technologies in East Africa - What happened to Africa's emerging maize revolution? Paper presented at the Foundation for Advanced Studies on International Development Forum V, December 8-10, Tokyo.

De Groote, H., Owuor, G., Doss, C., Ouma, J., Muhammad, L., Danda, K., 2005. The maize green revolution in Kenya revisited. Journal of Agriculture and Development Economics 2, 32-49. 
Diagne, A., Demont, M., 2007. Taking a new look at empirical models of adoption: Average treatment effect estimation of adoption rates and their determinants. Agricultural Economics 37, 201-210.

Diao, X., Pratt, A., 2007. Growth options and poverty reduction in Ethiopia-An economywide model analysis. Food Policy 32, 205-228.

Dibba, L., Fialor, S.C., Diagne, A., Nimoh, F., 2012. The impact of NERICA adoption on productivity and poverty of the small-scale rice farmers in the Gambia. Food Security 4, 253-265.

Dinavo, J.V., 1995. Privatization in developing countries: Its impact on economic development and democracy. Westport, CT: Greenwood Press.

Dorward, A., Kydd, J., Morrison, J., Urey, I., 2004. A policy agenda for pro-poor agricultural growth. World Development 32, 73-89.

Doss, C., 2003. Understanding farm level technology adoption: Lessons learned from CIMMYT’s micro surveys in Eastern Africa. CIMMYT Economics Working Paper 03-07. Mexico, D.F.: International Maize and Wheat Improvement Center.

Doss, C., Morris, M., 2001. How does gender affect the adoption of agricultural innovations? The case of improved maize technology in Ghana. Agricultural Economics 25, 27-39.

Due, J.M., 1993. Liberalization and privatization in Tanzania and Zambia. World Development 21, 1981-1988.

Duflo, E., Kremer, M., Robinson, J., 2008. How high are rates of return to fertilizer? Evidence from field experiments in Kenya. American Economic Review 98, 482-488.

Duflo, E., Kremer, M., Robinson, J., 2011. Nudging farmers to use fertilizer: Theory and experimental evidence from Kenya. American Economic Review 101, 2350-2390.

Feder, G., Just, R., Zilberman, D., 1985. Adoption of agricultural innovations in developing countries: A survey. Economic Development and Cultural Change 33, 255-298. 
Feleke, S., Zegeye, T., 2006. Adoption of improved maize varieties in Southern Ethiopia: Factors and strategy options. Food Policy 31, 442-457.

Finger, R., El Benni, N., Kaphengst, T., Evans, C., Herbert, S., Lehmann, B., Morse, S., Stupak, N., 2011. A meta analysis on farm-level costs and benefits of GM crops. Sustainability 3, 743-762.

Fischer, E., Qaim, M., 2012. Gender, agricultural commercialization, and collective action in Kenya. Food Security 4, 441-453.

Food and Agricultural Organisation Statistical Database (FAOSTAT), 2012. Production statistics. Available at: http://faostat.fao.org/site/567/default.aspx\#ancor. Accessed 29 May 2012.

Foster, A.D., Rosenzweig, M.R., 1995. Learning by doing and learning from others: Human capital and technical change in agriculture. Journal of Political Economy 103, 11761209.

Foster, A.D., Rosenzweig, M.R., 2010. Microeconomics of technology adoption. Annual Review of Economics 2, 395-424.

Friends of the Earth (FOE), 2011. Who benefits from GM crops: An industry built on myths. Amsterdam: Friends of the Earth International.

Genetic Resources Action International (GRAIN), 2010a . Global agribusiness: Two decades of plunder. Seedling, July 2010, 14-20.

Genetic Resources Action International (GRAIN), 2010b. Feeding the corporate coffers: Why hybrid rice continues to fail Asia’s small farmers. Seedling, April 2010, 28-29.

Glover, D., 2010. Is Bt cotton a pro-poor technology? A review and critique of the empirical record. Journal of Agrarian Change 10, 482-509.

Government of India (GOI), 2012. Monthly rainfall and temperature data. India Meteorological Department. Available at http://www.imd.gov.in. Accessed 7 May, 2012. 
Greenpeace, 2010. Economic failures: Genetic engineering enforces corporate control of agriculture. Amsterdam: Greenpeace International.

Griliches, Z., 1957. Hybrid corn: An exploration in the economics of technological change. Econometrica 25, 501-522.

Gruère, G., Sengupta, D., 2011. Bt cotton and farmer suicides in India: An evidence-based assessment. Journal of Development Studies 47, 316-337.

Gruère, G., Sun, Y., 2012. Measuring the contribution of Bt cotton adoption to India's cotton yields leap. IFPRI Discussion Paper 01170. Washington, DC: International Food Policy Research Institute.

Halvorsen, R., Palmquist, R., 1980. The interpretation of dummy variables in semilogarithmic equations. American Economic Review 70, 474-475.

Hassan, R., Mekuria, M., Mwangi, W., 2001. Maize breeding research in Eastern and Southern Africa: Current status and impact of past investments made by the public and private Sectors, 1966-97. Mexico, D.F.: International Maize and Wheat Improvement Center.

Heisey, P., Smale, M., 1995. Maize technology in Malawi: A green revolution in the making? Mexico, D.F.: International Maize and Wheat Improvement Center.

Huang, J., Mi, J., Lin, H., Wang, Z., Chen, R., Hu, R., Rozelle, S., Pray, C.E., 2010. A decade of Bt cotton in Chinese fields: Assessing the direct effects and indirect externalities of Bt cotton adoption in China. Science China Life Sciences 53, 981-991.

Hutchison W.D., Burkness, E.C., Mitchell, P.D., Moon, R.D., Leslie, T.W., Fleischer, S.J., Abrahamson, M., Hamilton, K.L., Steffey, K.L., Gray, M.E., Hellmich, R.L., Kaster, L.V., Hunt, T.E., Wright, R.J., Pecinovsky, K., Rabaey, T.L., Flood, B.R., Raun, E.S., 2010. Areawide suppression of European corn borer with Bt maize reaps savings to non-Bt maize growers. Science 330, 222-225. 
James, C., 2011. Global status of commercialized biotech/GM crops: 2011. ISAAA Brief 43. Ithaca, NY: International Service for the Acquisition of Agri-biotech Applications.

Japhether, W., de Groote, H., Lawrence, M., Kengo, D., Mohammed, L., 2006. Recycling hybrid maize varieties: Is it backward practice or innovative response to adverse conditions in Kenya? Paper presented at the International Association of Agricultural Economists Triennial Conference, August 12-18, Gold Coast.

Jayne, T.S., Govereh, J., Mwanaumo, A., Nyoro, J.K., Chapoto, A., 2002. False promise or false premise? The experience of food and input market reform in Eastern and Southern Africa. World Development 30, 1967-1985.

Kabunga, N.S., Dubois, T., Qaim, M., 2012a. Heterogeneous information exposure and technology adoption: The case of tissue culture bananas in Kenya. Agricultural Economics 43, 473-486.

Kabunga, N.S., Dubois, T., Qaim, M., 2012b. Yield effects of tissue culture bananas in Kenya: Accounting for selection bias and the role of complementary inputs. Journal of Agricultural Economics 63, 444-464.

Karihaloo, J.L., Kumar, P.A., 2009. Bt Cotton in India-A status report. 2nd Ed. New Delhi: Asia-Pacific Consortium on Agricultural Biotechnology.

Kassie, M., Shiferaw, B., Muricho, G., 2011. Agricultural technology, crop income, and poverty alleviation in Uganda. World Development 39, 1784-1795.

Kathage, J., Qaim, M., 2012. Economic impacts and impact dynamics of Bt (Bacillus thuringiensis) cotton in India. Proceedings of the National Academy of Sciences 109, 11652-11656.

Kathage, J., Qaim, M., Kassie, M., Shiferaw, B., 2012. Seed market liberalization, hybrid maize adoption, and impacts on smallholder farmers in Tanzania. GlobalFood Discussion Paper 12, Goettingen: University of Goettingen.

Kennedy, P., 2006. A guide to econometrics. Malden, MA: Blackwell Publishing. 
Kingsbury, N., 2009. Hybrid: The history and science of plant breeding. Chicago: University of Chicago Press.

Kolady, D.E., Spielman, D.J., Cavalieri, A., 2012. The impact of seed policy reforms and intellectual property rights on crop productivity in India. Journal of Agricultural Economics 63, 361-384.

Kouser, S., Qaim, M., 2011. Impact of Bt cotton on pesticide poisoning in smallholder agriculture: A panel data analysis. Ecological Economics 70, 2105-2113.

Krishna V.V., Qaim M., 2008. Potential impacts of Bt eggplant on economic surplus and farmers’ health in India. Agricultural Economics 38, 167-180.

Krishna, V.V., Qaim, M., 2012. Bt cotton and sustainability of pesticide reductions in India. Agricultural Systems 107, 47-55.

Kristjanson, P., Neufeldt, H., Gassner, A., Mango, J., Kyazze, F.B., Desta, S., Sayula, G., Thiede, B., Förch, W., Thornton, P.K., Coe, R., 2012. Are food insecure smallholder households making changes in their farming practices? Evidence from East Africa. Food Security 4, 381-397.

Langyintuo, A., Mwangi, W., Diallo, A., MacRobert, J., Dixon, J., 2010. Challenges of the maize seed industry in Eastern and Southern Africa: A compelling case for privatepublic intervention to promote growth. Food Policy 35, 323-331.

Limbu, F.L., Mashindano, O.J.N., 2002. The agricultural sector and poverty in Tanzania: The impact and future of the reform process, in Mbelle, A., Mjema, G., Kilindo, A. (Eds.), The Nyerere legacy and economic policy making in Tanzania. Dar es Salaam: Dar es Salaam University Press, pp. 41-71.

Lipton, M., 2010. From policy aims and small-farm characteristics to farm science needs. World Development 38, 1399-1412.

Matuschke, I., Mishra, R., Qaim, M., 2007. Adoption and impact of hybrid wheat in India. World Development 35, 1422-1435. 
Matuschke, I., Qaim, M., 2008. Seed market privatisation and farmers' access to crop technologies: The case of hybrid pearl millet adoption in India. Journal of Agricultural Economics 59, 498-515.

Matuschke, I., Qaim, M., 2009. The impact of social networks on hybrid seed adoption in India. Agricultural Economics 40, 493-505.

Minot, N., Smale, M., Eicher, C., Jayne, T., Kling, D., Horna, D., Meyers, R., 2007. Seed development programs in Sub-Saharan Africa: A review of experiences. Prepared for the Rockefeller Foundation. Washington, DC: International Food Policy Research Institute.

Morris, M., 2002. Impacts of international maize breeding research in developing countries, 1966-98. Mexico, D.F.: International Maize and Wheat Improvement Center.

Morse, S., Bennett, R., Ismael, Y., 2007. Inequality and GM crops: A case-study of Bt cotton in India. AgBioForum 10, 44-50.

Murugkar, M., Ramaswami, B., Shelar, M., 2007. Competition and monopoly in Indian cotton seed market. Economic and Political Weekly 42, 3781-3789.

Naseem, A., Spielman, D.J., Omamo, S.W., 2010. Private-sector investment in R\&D: A review of policy options to promote its growth in developing-country agriculture. Agribusiness 26, 143-173.

Noltze, M., Schwarze, S., Qaim, M., 2012. Understanding the adoption of system technologies in smallholder agriculture: The system of rice intensification (SRI) in Timor Leste. Agricultural Systems 108, 64-73.

Olmstead, A.L., Rhode, P.W., 2008. Creating Abundance: Biological innovation and American agricultural development. New York: Cambridge University Press.

Paarlberg, R., 2008. Starved for Science: How biotechnology is being kept out of Africa. Cambridge, MA: Harvard University Press. 
Pardey, P.G., Alston, J.M., Chan-Kang, C., 2012. Agricultural production, productivity and R\&D over the past half century: An emerging new world order. Paper presented at the International Association of Agricultural Economists Triennial Conference, August 18-24, Foz do Iguaçu.

Pingali, P.L., Traxler, G., 2002. Changing locus of agricultural research: Will the poor benefit from biotechnology and privatization trends? Food Policy 27, 223-238.

Ponte, S., 2001. Policy reforms, market failures and inputs use in African smallholder agriculture. The European Journal of Development Research 13, 1-29.

Pray, C.E., Huang, J., Hu, R., Rozelle, S., 2002. Five years of Bt cotton in China-The benefits continue. Plant Journal 31, 423-430.

Pray, C.E., Ramaswami, B., 1991. A framework for seed policy analysis in developing countries. Washington, DC: International Food Policy Research Institute.

Pray, C.E., Ramaswami, B., 1999. Liberalization's impact on the Indian seed industry: Competition, research, and impact on farmers. The International Food and Agribusiness Management Review 2, 407-420.

Pray, C.E., Ramaswami, B., Kelley, T., 2001. The impact of economic reforms on R\&D by the Indian seed industry. Food Policy 26, 587-598.

Pray, C.E., Umali-Deininger, D., 1998. The private sector in agricultural research systems: Will it fill the gap? World Development 26, 1127-1148.

Putterman, L., 1995. Economic reform and smallholder agriculture in Tanzania: A discussion of recent market liberalization, road rehabilitation, and technology dissemination efforts. World Development 23, 311-326.

Qaim, M., 2003. Bt cotton in India: Field trial results and economic projections. World Development 31, 2115-2127.

Qaim M., 2009. The economics of genetically modified crops. Annual Review of Resource Economics 1, 665-693. 
Qaim, M., Subramanian, A., Naik, G., Zilberman, D., 2006. Adoption of Bt cotton and impact variability: Insights from India. Review of Agricultural Economics 28, 48-58.

Qaim, M., Zilberman, D., 2003. Yield effects of genetically modified crops in developing countries. Science 299, 900-902.

Rubin, D.B., 1973. Matching to remove bias in observational studies. Biometrics 29, 159-183.

Ruttan, V.W., 2001. Technology, growth, and development: An induced innovation perspective. New York: Oxford University Press.

Sadashivappa, P., Qaim, M., 2009. Bt cotton in India: Development of benefits and the role of government seed price interventions. AgBioForum 12, 172-183.

Shiferaw, B., Prasanna, B.M., Hellin, J., Bänziger, M., 2011. Crops that feed the world 6. Past successes and future challenges to the role played by maize in global food security. Food Security 3, 307-327.

Shiva, V., Barker, D., Lockhart, C., 2011. The GMO emperor has no clothes. Florence: Navdanya International.

Smale, M., Heisey, P., Leathers, H., 1995. Maize of the ancestors and modern varieties: The microeconomics of high-yielding variety adoption in Malawi. Economic Development and Cultural Change 43, 351-368.

Smale, M., Jayne, T., 2003. Maize in Eastern and Southern Africa: 'Seeds' of success in retrospect. EPTD Discussion Paper No. 97. Washington, DC: International Food Policy Research Institute.

Spielman, D., Byerlee, D., Alemu, D., Kelemework, D., 2010. Policies to promote cereal intensification in Ethiopia: The search for appropriate public and private roles. Food Policy 35, 185-194.

Stock, J.H., Yogo, M., 2005. Testing for weak instruments in linear IV regression, in Andrews, D.W.K., Stock, J.H. (Eds.), Identification and inference for econometric 
models: Essays in honor of Thomas Rothenberg. New York: Cambridge University Press, pp. 80-108.

Stone, G.D., 2011. Field versus farm in Warangal: Bt cotton, higher yields, and larger questions. World Development 39, 387-398.

Subramanian, A., Qaim, M., 2009. Village-wide effects of agricultural biotechnology: The case of Bt cotton in India. World Development 37, 256-267.

Subramanian, A., Qaim, M., 2010. The impact of Bt cotton on poor households in rural India. Journal of Development Studies 46, 295-311.

Suri, T., 2011. Selection and comparative advantage in technology adoption. Econometrica 79, 159-209.

Tabashnik, B.E., 2008. Delaying insect resistance to transgenic crops. Proceedings of the National Academy of Sciences 105, 19029-19030.

Thirtle, C., Lin, L., Piesse, J., 2003. The impact of research-led agricultural productivity growth on poverty reduction in Africa, Asia and Latin America. World Development 31, 1959-1975.

Tiffin, R., Irz, X., 2006. Is agriculture the engine of growth? Agricultural Economics 35, 7990.

Tripp, R., Louwaars, N., 1997. Seed regulation: Choices on the road to reform. Food Policy 22, 433-446.

Tripp, R., Pal, S., 2001. The private delivery of public crop varieties: Rice in Andhra Pradesh. World Development 29, 103-117.

Union of Concerned Scientists (UCS), 2009. Failure to yield: Evaluating the performance of genetically engineered crops. Cambridge, MA: UCS Publications.

Van de Walle, N., 1989. Privatization in developing countries: A review of the issues. World Development 17, 601-615. 
Vickers, J., Yarrow, G., 1989. Privatization: An economic analysis. Cambridge, MA: MIT Press.

Wang, S., Just, D.R., Pinstrup-Andersen, P., 2008. Bt-cotton and secondary pests. International Journal of Biotechnology 10, 113-121.

Wang, Z.-j., Lin, H., Huang, J.-k., Hu, R.-f., Rozelle, S., Pray, C.E., 2009. Bt cotton in China: Are secondary insect infestations offsetting the benefits in farmer fields? Agricultural Sciences in China 8, 83-90.

Wright, B.D., Pardey, P.G., 2006. The evolving rights to intellectual property protection in the agricultural biosciences. International Journal of Technology and Globalisation 2, $12-$ 29.

Wu, K.M., Lu, Y.H., Feng, H.Q., Jiang, Y.Y., Zhao, J.Z., 2008. Suppression of cotton bollworm in multiple crops in China in areas with Bt toxin-containing cotton. Science 321, 1676-1678. 


\section{Appendix A}

\section{Additional Tables}

Table A1: Descriptive Statistics for 1,655 Plots and 533 Associated Households (Averages for 2002-2004 and 2006-2008)

\begin{tabular}{|c|c|c|c|c|}
\hline & \multicolumn{2}{|c|}{$2002-2004$} & \multicolumn{2}{|c|}{$2006-2008$} \\
\hline & Conventional & $\mathrm{Bt}$ & Conventional & $\mathrm{Bt}$ \\
\hline \multicolumn{5}{|l|}{ Plot level information } \\
\hline Seed cost $(1,000$ & $0.51(0.26)$ & $1.60 * * *(0.43)$ & $0.47(0.21)$ & $0.91 * * *(0.32)$ \\
\hline \multicolumn{5}{|l|}{ Rs/acre) } \\
\hline Seed rate (g/acre) & $659.82 * * *(552.39)$ & 490.72 (114.23) & $646.64 * * *(474.33)$ & 570.75 (160.93) \\
\hline $\begin{array}{l}\text { Irrigation (share of } \\
\text { plots) }\end{array}$ & $0.46(0.50)$ & $0.58^{* * *}(0.49)$ & $0.48(0.50)$ & $0.59 *(0.49)$ \\
\hline Fertilizer (t/acre) & $0.23(0.15)$ & $0.26 * * *(0.16)$ & $0.20(0.10)$ & $0.25^{* * *}(0.15)$ \\
\hline Pesticide $(1,000$ & $2.27 * * *(1.80)$ & $1.43(1.57)$ & $1.07(1.21)$ & $1.07(1.38)$ \\
\hline \multicolumn{5}{|l|}{ Rs/acre) } \\
\hline Labor (d/acre) & $70.72(32.30)$ & $83.23 * * *(40.81)$ & $63.12(35.74)$ & $69.75(44.67)$ \\
\hline Yield (kg/acre) & 520.64 (315.54) & $705.40 * * *(360.41)$ & 588.85 (318.66) & $829.03^{* * *}(341.08)$ \\
\hline Cotton price (Rs/kg) & $19.67(3.06)$ & 19.52 (2.69) & 20.07 (4.87) & $23.31 * * *(4.05)$ \\
\hline Revenue $(1,000$ & $10.22(6.36)$ & $13.79 * * *(7.32)$ & $12.41(7.48)$ & $19.35 * * *(8.42)$ \\
\hline \multicolumn{5}{|l|}{ Rs/acre) } \\
\hline Total cost $(1,000$ & $6.62(3.07)$ & $7.65^{* * *}(2.94)$ & $7.10(3.34)$ & $9.03 * * *(5.12)$ \\
\hline \multicolumn{5}{|l|}{ Rs/acre) } \\
\hline Profit $(1,000$ & $3.60(5.80)$ & $6.14 * * *(6.89)$ & $5.31(6.80)$ & $10.32 * * *(7.73)$ \\
\hline \multicolumn{5}{|l|}{ Rs/acre) } \\
\hline No. of plots & 601 & 298 & 64 & 692 \\
\hline \multicolumn{5}{|c|}{ Household level information } \\
\hline $\begin{array}{l}\text { Age of farmer } \\
\text { (years) }\end{array}$ & $44.24(12.49)$ & $44.43(12.47)$ & $48.14 * *(12.52)$ & $45.18(12.67)$ \\
\hline $\begin{array}{l}\text { Education of farmer } \\
\text { (years) }\end{array}$ & $7.29(4.97)$ & $8.04 * *(4.81)$ & $4.73(5.08)$ & $7.32 * * *(5.15)$ \\
\hline Land owned (acres) & $13.25(15.45)$ & $15.07 *(18.42)$ & $11.48(12.28)$ & $11.61(12.68)$ \\
\hline Cotton area (acres) & $6.99(37.12)$ & $6.20(6.73)$ & $4.42(4.51)$ & $5.79 * *(4.60)$ \\
\hline $\begin{array}{l}\text { Household size } \\
\text { (head) }\end{array}$ & $6.46(3.46)$ & $6.75(3.80)$ & $6.59(3.38)$ & $6.28(4.07)$ \\
\hline Expenditures $(1,000$ & $85.87(71.01)$ & $122.76^{* * *}(79.00)$ & $87.90(64.14)$ & $90.43(88.82)$ \\
\hline Rs/year) & & & & \\
\hline
\end{tabular}


Table A1 (continued)

\begin{tabular}{lcccc}
\hline & \multicolumn{2}{c}{$2002-2004$} & & $2006-2008$ \\
\cline { 2 - 5 } & Conventional & Bt & Conventional & Bt \\
\hline $\begin{array}{l}\text { Number of } \\
\text { households }\end{array}$ & 363 & 222 & 61 & 432 \\
\hline$*, * *, * * *$ imply that the mean value is significantly higher than that of conventional/Bt in the same time period
\end{tabular}
at the $10 \%, 5 \%$, and $1 \%$ level, respectively. Mean values are shown with standard deviations in parentheses. Household expenditures were deflated using the consumer price index. Rs, Indian Rupees. Source: Author's calculations. 
Table A2: Estimated Coefficients of Quadratic Production (Yield) Function

\begin{tabular}{|c|c|c|c|}
\hline & \multirow{2}{*}{$\begin{array}{c}\text { Pooled-data model } \\
1\end{array}$} & \multicolumn{2}{|c|}{ Fixed-effects models } \\
\hline & & 2 & 3 \\
\hline \multicolumn{4}{|l|}{ Inputs } \\
\hline Bt (dummy) & $156.46^{* * *}(21.85)$ & $125.90^{* * *}(20.41)$ & $116.91^{* * *}(20.68)$ \\
\hline Bt 2006-2008 (dummy) & 31.62 (44.79) & $3.59(43.46)$ & $180.06^{* * *}(20.54)$ \\
\hline Seed rate (g/acre) & $0.54 * *(0.02)$ & $-0.004(0.03)$ & $-0.01(0.03)$ \\
\hline Sow date (days) & $0.23(0.40)$ & $-0.85^{* *}(0.42)$ & $-0.86^{* *}(0.44)$ \\
\hline Harvest date (days) & $1.16^{* * *}(0.27)$ & $1.03^{* * *}(0.29)$ & $-0.08(0.25)$ \\
\hline Irrigation (yes/no) & $139.75^{* * *}(15.80)$ & $97.26^{* * *}(19.35)$ & $83.00 * * *(0.00)$ \\
\hline Fertilizer (t/acre) & $70.61(135.43)$ & $1.29(144.01)$ & $-29.08(149.13)$ \\
\hline Fertilizer squared & $844.08 * *(351.59)$ & $558.55(358.62)$ & $646.46 *(371.64)$ \\
\hline Pesticide (1,000 Rs/acre) & $20.62(13.17)$ & $1.72(14.24)$ & $-8.91(13.58)$ \\
\hline Pesticide squared & $-1.85(2.91)$ & $-1.86(2.94)$ & $-1.52(3.03)$ \\
\hline Labor (days/acre) & $4.44 * * *(0.55)$ & $5.11^{* * *}(0.69)$ & $4.83^{* * *}(0.72)$ \\
\hline Labor squared & $-0.01 * * *(0.003)$ & $-0.02 * * *(0.01)$ & $-0.01 * *(0.01)$ \\
\hline Fertilizer-pesticide interaction & $-72.08 * * *(27.31)$ & $-35.28(27.95)$ & $-38.85(28.97)$ \\
\hline Fertilizer-labor interaction & $-1.77(1.22)$ & $-2.91 * *(1.35)$ & $-3.23 * *(1.39)$ \\
\hline Pesticide-labor interaction & $0.14(0.13)$ & $0.17(0.14)$ & $0.29 * *(0.14)$ \\
\hline \multicolumn{4}{|l|}{ Household characteristics } \\
\hline Age of farmer (years) & $-2.34 * * *(0.65)$ & & \\
\hline Education of farmer (years) & $-0.29(1.55)$ & & \\
\hline Cotton experience of farmer (years) & $0.62(0.91)$ & & \\
\hline Karnataka & $-9.89(20.64)$ & & \\
\hline Andhra Pradesh & $19.43(20.87)$ & & \\
\hline Tamil Nadu & $-193.54 * * *(40.79)$ & & \\
\hline 2004 & $103.94 * * *(19.91)$ & $125.39 * * *(17.68)$ & \\
\hline 2006 & $235.41^{* * *}(41.42)$ & $297.03^{* * *}(40.53)$ & \\
\hline 2008 & $128.01 * * *(44.64)$ & $208.61 * * *(43.68)$ & \\
\hline Constant & $-130.12(82.19)$ & $-104.19(83.07)$ & $287.23^{* * *}(69.10)$ \\
\hline Number of observations & 1648 & 1648 & 1648 \\
\hline $\mathrm{R}^{2}$ & 0.38 & 0.39 & 0.34 \\
\hline Hausman test & & $90.47 * * *$ & $70.00 * * *$ \\
\hline
\end{tabular}

$*, * *, * * *$, Coefficient is statistically significant at the $10 \%, 5 \%$, and $1 \%$ level, respectively. The model in column 1 is based on comparisons of plots both within and between households. Columns 2 and 3 are based on comparisons of plots within households (household fixed effects). The dependent variable in all three models is cotton yield in kg per acre. Coefficient estimates are shown with standard errors in parentheses. The reference year is 2002. The Hausman test results show that fixed-effects are preferred over random-effects specifications. Rs, Indian Rupees. Source: Author's estimations. 
Table A3: Estimated Coefficients of Quadratic Profit Function

\begin{tabular}{|c|c|c|c|}
\hline & \multirow{2}{*}{$\begin{array}{c}\text { Pooled-data model } \\
1\end{array}$} & \multicolumn{2}{|c|}{ Fixed-effects models } \\
\hline & & 2 & 3 \\
\hline \multicolumn{4}{|l|}{ Inputs } \\
\hline Bt (dummy) & $1,595.67 *(847.63)$ & $1,877.21 * *(889.16)$ & $2,151.51 * *(893.33)$ \\
\hline Bt 2006-2008 (dummy) & 1,485.88 (1,087.64) & $-260.45(1,144.58)$ & 1,736.39** (803.31) \\
\hline Seed rate (g/acre) & $0.72(0.47)$ & $0.09(0.63)$ & $-0.07(0.63)$ \\
\hline Sow date (days) & $-4.56(8.47)$ & $-18.37 *(9.59)$ & $-19.92 * *(9.72)$ \\
\hline Harvest date (days) & $14.26 * *(5.73)$ & $13.72 * *(6.73)$ & $-2.36(6.15)$ \\
\hline Irrigation (yes/no) & $2,922.27 * * *(318.20)$ & $2,087.24 * * *(439.54)$ & $2,027.25^{* * *}(442.23)$ \\
\hline Seed price (Rs/450g) & $0.71(0.70)$ & $0.16(0.76)$ & $-0.35(0.76)$ \\
\hline Cotton price (Rs/kg) & $812.81 * * *(64.91)$ & $814.17 * * *(71.21)$ & $615.53 * * *(53.88)$ \\
\hline Fertilizer price (Rs/kg) & $-286.88 * * *(90.49)$ & $-361.04 * * *(98.40)$ & $-340.12 * * *(99.74)$ \\
\hline Fertilizer price squared & $6.37 * * *(1.98)$ & $8.39 * * *(2.21)$ & $7.58^{* * *}(2.24)$ \\
\hline Pesticide price (Rs/liter) & $0.60(0.43)$ & $0.05(0.48)$ & $0.53(0.47)$ \\
\hline Pesticide price squared & $0.0001(0.0001)$ & $0.0002 *(0.0001)$ & $0.0001(0.0001)$ \\
\hline Wage rate (Rs/hour) & 138.38 (136.08) & $-74.12(152.33)$ & $230.42(145.12)$ \\
\hline Wage rate squared & $-10.50 *(6.00)$ & $-3.27(9.37)$ & $-23.84 * * *(8.84)$ \\
\hline $\begin{array}{l}\text { Fertilizer-pesticide price } \\
\text { interaction }\end{array}$ & $-0.10 * * *(0.02)$ & $-0.09 * * *(0.02)$ & $-0.09 * * *(0.02)$ \\
\hline $\begin{array}{l}\text { Fertilizer-labor price inter- } \\
\text { action }\end{array}$ & $18.45(13.78)$ & $3.20(15.66)$ & $7.45(15.83)$ \\
\hline $\begin{array}{l}\text { Pesticide-labor price inter- } \\
\text { action }\end{array}$ & $-0.01(0.03)$ & $0.02(0.04)$ & $-0.00004(0.04)$ \\
\hline Household characteristics & & & \\
\hline Age of farmer (years) & $-45.37 * * *(13.71)$ & & \\
\hline Education of farmer (years) & $5.43(32.59)$ & & \\
\hline $\begin{array}{l}\text { Cotton experience of farmer } \\
\text { (years) }\end{array}$ & $2.12(19.25)$ & & \\
\hline Karnataka & $997.04 * *(428.77)$ & & \\
\hline Andhra Pradesh & $-757.56 *(412.86)$ & & \\
\hline Tamil Nadu & $-2,331.92 * * *(825.00)$ & & \\
\hline 2004 & $1,454.26 * * *(464.90)$ & $2,066.07 * * *(466.18)$ & \\
\hline 2006 & 2,093.82** (933.78) & $5,006.86^{* * *}(1,017.09)$ & \\
\hline 2008 & $-1,389.82(1,064.79)$ & $2,332.61 * *(1,149.50)$ & \\
\hline Constant & $-15,530.24^{* * *}(2,276.21)$ & $-14,554.41^{* * *}(2,268.62)$ & $-6,492.66 * * *(1,676.44)$ \\
\hline Number of observations & 1648 & 1648 & 1648 \\
\hline $\mathrm{R}^{2}$ & 0.35 & 0.38 & 0.36 \\
\hline Hausman test & & $42.39 * * *$ & $24.60 * *$ \\
\hline
\end{tabular}




\section{Table A3 (continued)}

$*, * *, * * *$, Coefficient is statistically significant at the $10 \%, 5 \%$, and $1 \%$ level, respectively. The model in column 1 is based on comparisons of plots both within and between households. Columns 2 and 3 are based on comparisons of plots within households (household fixed effects). The dependent variable in all three models is cotton profit in Indian Rupees (Rs) per acre. Coefficient estimates are shown with standard errors in parentheses. The reference year is 2002. The Hausman test results show that fixed-effects are preferred over random-effects specifications. Source: Author’s estimations. 
Table A4: Estimated Coefficients of Household Consumption Expenditure Function

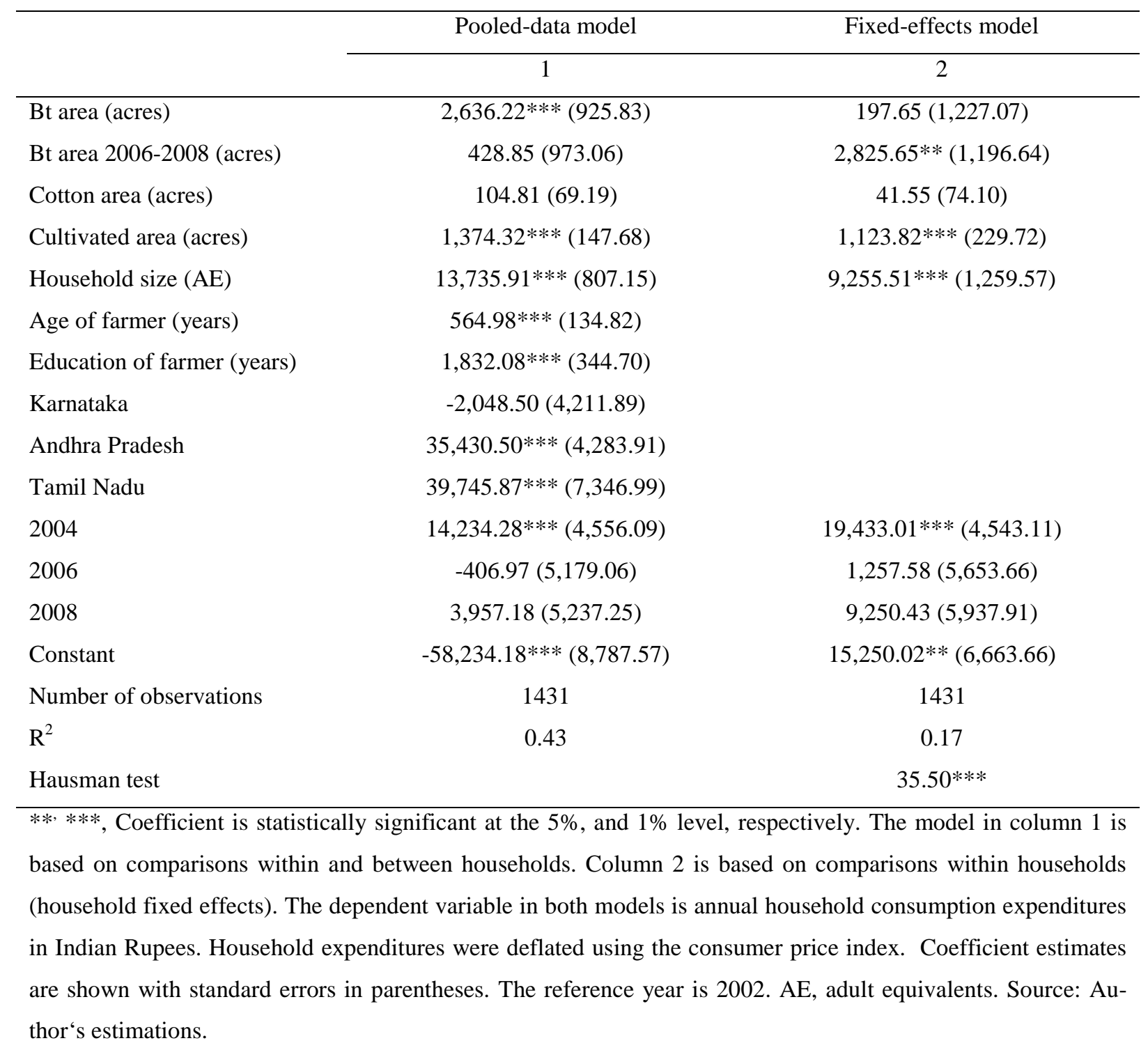




\section{Appendix B}

\section{Household Questionnaire (Tanzania)}

\section{Sustainable Intensification of Maize-Legume Cropping Systems for Food Security in Eastern and Southern Africa (SIMLESA) Project}

\section{Baseline Survey Household Questionnaire for Tanzania - 2010}

Selian Agricultural Research Institute (SARI) and Agricultural Research Institute Ilonga (ARI-ILonga) in Partnership with

International Maize and Wheat Improvement Center (CIMMYT)

\section{PART O. INTERVIEW BACKGROUND}

1. Respondent's name:

2. Mobile phone No.

Landline phone no

3. Date of interview: Day:

Month:

Year:

4. Interviewed by (enumerator's name):

5. Date checked: Day:

Month:

Year:

6. Checked by (supervisor's name)

7. Date entered: Day:

Month:

Year:

8. Entered by:

9. Zone

10. Region

11. District:

13. Division

14. Ward

15. Village 


\section{PART 1. FARMERS IDENTIFICATION AND VILLAGE CHARACTERISTICS}

1. Major family language

2. Religion of the household head (Codes A).

3. Does main residential house have the following inbuilt? (Codes B) 1. Kitchen.....

2. Grain store.

4. Type of toilet used
; 3. Livestock pen.

1. Flash toilet private; 2. Flash toilet shared; 3. Pit latrine private;

4. Pit latrine shared; 5. Bucket latrine; 6. No toilet/use open air

5. Main walling material of main residential house.

(Codes C)

6. Main roofing material of main residential house.... (Codes D)

7. Experience in growing maize (years)

8. Experience in growing legumes (years) Haricot bean Cowpea. (Other, specify name)

Soybean Pigeonpea
Groundnut.

Years of experience.

9. Taking all means into consideration (own food production + food purchase + help from different sources + food hunted from forest and lakes, etc), how would you define your family's food consumption in the last year?

1. Food shortage through the year, 2. Occasional food shortage, 3. No food shortage but no surplus, 4. Food surplus.

10.

11.

12.

13.

15.

16.

17.

18.

19.

20.

21.

22.

23.

24.

25.

26.

27.

Distance to the village market from residence $(\mathrm{km})$ minutes of walking time

What means of transport do you use mainly to get to the village market? (Code E)....

Average single trip transport cost (per person) to the village market using this means of transport (TSh/person)

Distance to the nearest main market from residence $(\mathrm{km})$. minutes of walking time.

Number of months road to main market is passable for cars in a year.

Quality of road to the main market.

$.1=$ Very poor; $2=$ Poor; $3=$ Average; $4=$ Good; 5= Very good Average single transport cost (per person) to the main market using a car (TSh/person)

Distance to the nearest source of seed dealer from residence $(\mathrm{km})$ minutes of walking time

Distance to the nearest source of fertilizer dealer from residence $(\mathrm{km})$ minutes of walking time

Distance to nearest source of herbicides and pesticides dealer from residence $(\mathrm{km})$. .minutes of walking time

Distance to the nearest farmer cooperative from residence $(\mathrm{km})$. minutes of walking time Distance to the nearest farmers group from residence $(\mathrm{km})$. minutes of walking time Distance to the nearest agricultural extension office from residence $(\mathrm{km})$. minutes of walking time. Distance to the nearest health center from residence $(\mathrm{km})$. .minutes of walking time.

Main source of drinking water (Codes F below)

Do you boil water for drinking? (Codes B)

Distance to main water source for drinking from residence (km). .minutes of walking time.
GPS readings of village: a) Altitude.
; b) Latitude.
; c) Longitude.

Codes A: 0. No religion/atheist; 1. Orthodox Christian; 2. Catholic; 3. Protestant; 4. Other Christian 5. Muslim; 6. Other, specify.....

Codes B: 1. Yes: 0.No

Codes C: 1 . Burned bricks; 2. Unburned bricks; 3. Stone; 4. Earth; 5. Wooden (timber); 6. Other, specify.....

Codes D: 1 . Grass thatch; 2. Iron sheet; 3. Tiles; 4. Other, specify.

Codes E: 1. Walking; 2. Bicycle; 3. Tractor; 4. Minibus; 5. Other, specify.

Codes F: 1. Piped; 2. Borehole protected and covered; 3. Borehole unprotected \& uncovered; 4. Stream; 5. River; 6. Lake;

7. Ponds or floods Note: protected refers to water sources internally plastered and covered with a cap of wood, stone or concrete) 
PART 2: CURRENT HOUSEHOLD COMPOSITION AND CHARACTERISTICS

\begin{tabular}{|c|c|c|c|c|c|c|c|c|c|c|c|c|}
\hline \multirow[b]{2}{*}{ 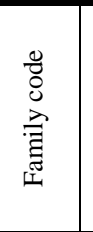 } & \multirow[b]{2}{*}{$\begin{array}{l}\text { Name of household member } \\
\text { (start with respondent) }\end{array}$} & \multirow[b]{2}{*}{ ஸे } & \multirow[b]{2}{*}{ 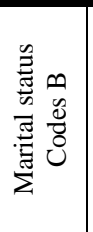 } & \multirow[b]{2}{*}{ 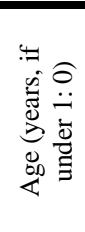 } & \multirow[b]{2}{*}{$\begin{array}{l}\text { Education } \\
\text { (years) } \\
\text { Codes C }\end{array}$} & \multirow[b]{2}{*}{$\begin{array}{l}\text { Relation } \\
\text { to HH } \\
\text { Codes D }\end{array}$} & \multicolumn{2}{|c|}{$\begin{array}{l}\text { Occupation } \\
\text { Codes E }\end{array}$} & \multirow[b]{2}{*}{$\begin{array}{l}\text { Own farm } \\
\text { labour } \\
\text { contribution } \\
\text { Codes F }\end{array}$} & \multicolumn{3}{|c|}{$\begin{array}{l}\text { For those under the age of } 6 \text { (see } \\
\text { column 5) }\end{array}$} \\
\hline & & & & & & & Main & Secondary & & $\begin{array}{l}\text { Weight } \\
(\mathrm{kg})\end{array}$ & $\begin{array}{l}\text { Height } \\
(\mathrm{cm})\end{array}$ & $\begin{array}{c}\text { Had } \\
\text { diarrhea } \\
\text { in } \\
2009 / 10 \\
\text { Codes G }\end{array}$ \\
\hline 1 & 2 & 3 & 4 & 5 & 6 & 7 & 8 & 9 & 10 & 11 & 12 & 13 \\
\hline \multicolumn{13}{|l|}{01} \\
\hline \multicolumn{13}{|l|}{02} \\
\hline \multicolumn{13}{|l|}{03} \\
\hline \multicolumn{13}{|l|}{04} \\
\hline \multicolumn{13}{|l|}{05} \\
\hline \multicolumn{13}{|l|}{06} \\
\hline \multicolumn{13}{|l|}{07} \\
\hline \multicolumn{13}{|l|}{08} \\
\hline \multicolumn{13}{|l|}{09} \\
\hline \multicolumn{13}{|l|}{10} \\
\hline \multicolumn{13}{|l|}{11} \\
\hline \multicolumn{13}{|l|}{12} \\
\hline \multicolumn{13}{|l|}{13} \\
\hline \multicolumn{13}{|l|}{14} \\
\hline \multicolumn{13}{|l|}{15} \\
\hline \multicolumn{13}{|l|}{16} \\
\hline \multicolumn{13}{|l|}{17} \\
\hline \multicolumn{13}{|l|}{18} \\
\hline \multicolumn{13}{|l|}{19} \\
\hline 20 & & & & & & & & & & & & \\
\hline 21 & & & & & & & & & & & & \\
\hline 22 & & & & & & & & & & & & \\
\hline 23 & & & & & & & & & & & & \\
\hline 24 & & & & & & & & & & & & \\
\hline $\begin{array}{l}\text { Codes A } \\
0 \text {. Female } \\
1 \text {. Male }\end{array}$ & $\begin{array}{l}\text { Codes B } \\
\text { 1. Married living with spouse } \\
\text { 2. Married but spouse away } \\
\text { 3. Divorced/separated } \\
\text { 4. Widow/widower } \\
\text { 5. Never married } \\
\text { 6. Other, specify...... }\end{array}$ & & $\begin{array}{l}\text { des C } \\
\text { None/Ill } \\
\text { Adult ed } \\
1 \text { year o } \\
\text { ucation } \\
\text { Give oth } \\
\text { ucation } \\
\text { mpleted }\end{array}$ & $\begin{array}{l}\text { iterate } \\
\text { ucation } \\
\text { er } \\
\text { n years }\end{array}$ & $\begin{array}{l}\text { Codes D } \\
\text { 1. House } \\
\text { 2. Spous } \\
\text { 3. Son/dz } \\
\text { 4. Parent } \\
\text { 5. Son/dic } \\
\text { 6. Grand } \\
\text { 7. Other } \\
\text { 8. Hired } \\
\text { 9. Other, }\end{array}$ & $\begin{array}{l}\text { old head } \\
\text { ughter } \\
\text { ughter in-law } \\
\text { child } \\
\text { elative } \\
\text { vorker } \\
\text { specify....... }\end{array}$ & $\begin{array}{l}\text { Cod } \\
\text { 1. F. } \\
\text { 2. S. } \\
\text { 3. S } \\
\text { 4. C } \\
\text { 5. C } \\
\text { 6. S } \\
\text { 7. N } \\
\text { 8. H } \\
\text { 9. H } \\
10 .\end{array}$ & $\begin{array}{l}\text { les E } \\
\text { arming (crop } \\
\text { alaried employ } \\
\text { elf-employed } \\
\text { asual labourer } \\
\text { asual labourer } \\
\text { chool/college } \\
\text { on-school chil } \\
\text { erding } \\
\text { Oousehold chor } \\
\text { Other, specify }\end{array}$ & $\begin{array}{l}\text { livestock) } \\
\text { ment } \\
\text { fff-farm } \\
\text { on-farm } \\
\text { off-farm } \\
\text { thild } \\
\text { d } \\
\text { es } \\
\text {.......... }\end{array}$ & $\begin{array}{l}\text { Codes F } \\
1.100 \% \\
\text { 2. } 75 \% \\
\text { 3. } 50 \% \\
\text { 4. } 25 \% \\
\text { 5. } 10 \% \\
\text { 6. Not a worker }\end{array}$ & & $\begin{array}{l}\text { les } \mathbf{G} \\
\text { Io } \\
\text { es }\end{array}$ \\
\hline
\end{tabular}


PART 3: SOCIAL CAPITAL AND NETWORKING

Section A. Membership in formal and informal institutions in the last 3 years (husband and wife/wives only. One group membership per row.)

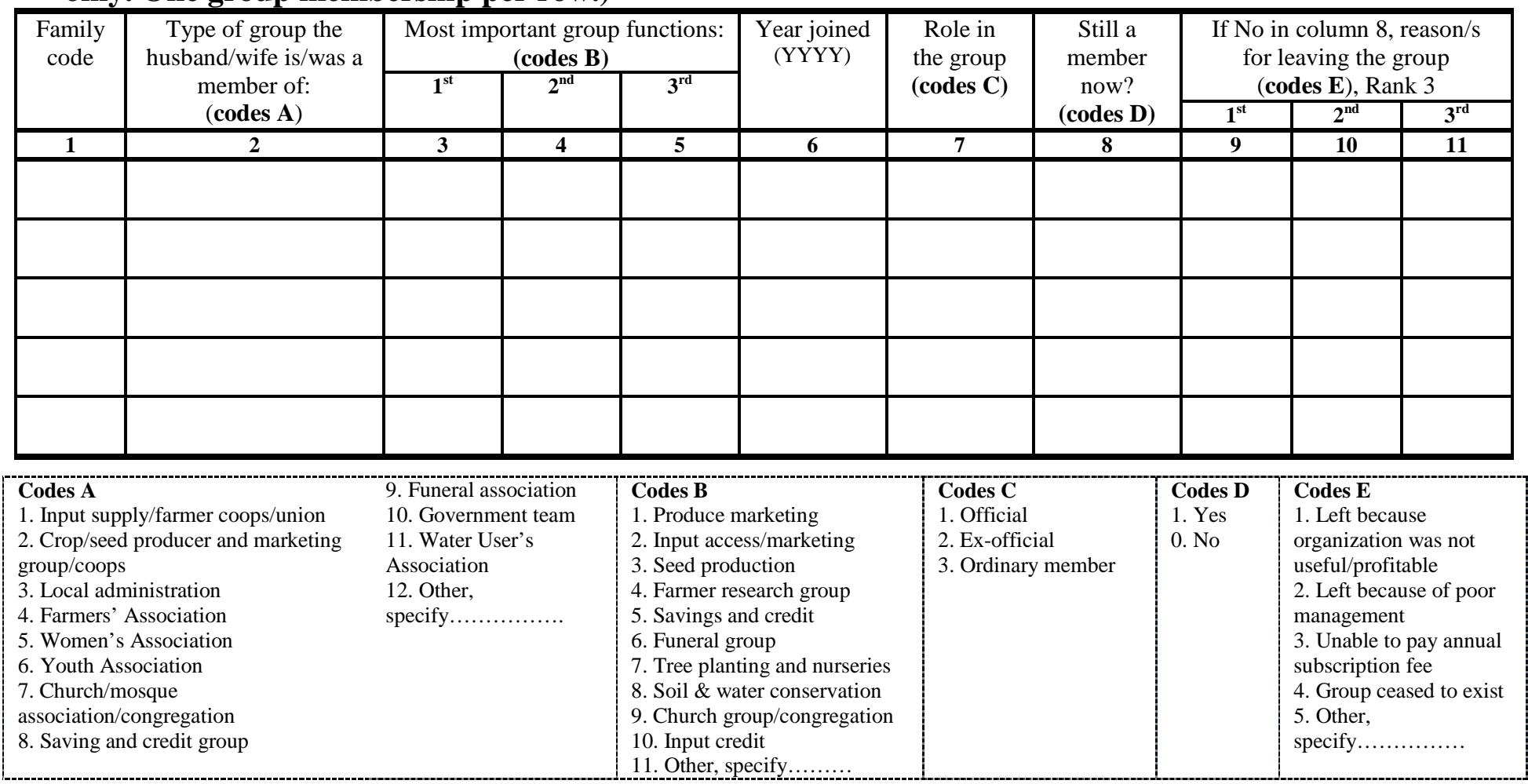

\section{Section B. Social networks}

1. Number of years the respondent has been living in this village

2. Number of people that you can rely on for critical support in times of need within this village

Relatives .Non-Relatives

3. Number of people you can rely on for support in times of need outside this village

Relatives ..; Non-Relatives

4. Are any of your friends or relatives in leadership positions in formal or informal institutions?

Codes: 1 . Yes, 0 . No

5. Number of grain traders that you know in this village who could buy your grain.....

6. Number of grain traders that you know outside this village who could buy your grain

7. Generally speaking, would you say that most traders can be trusted?.

.(Codes A below)

8. If answer in Question 7 above is 1, 2 or 3, then which types of traders do you trust more? - give names.

And why do you trust these types of traders more?.

9. Do you think you can rely on government support (subsidies, food aid etc) if your crop fails?.......

Codes: 1.Yes; 0. No

10. Are you confident of the skills of government officials including extension workers to do their job? (Codes A)

Codes A: 1. Strongly disagree; 2. Disagree; 3. Slightly disagree; 4. Slightly agree; 5. Agree; 6. Strongly agree 


\section{PART 4. HOUSEHOLD ASSETS}

\section{Section A: Production equipments and major household furniture}

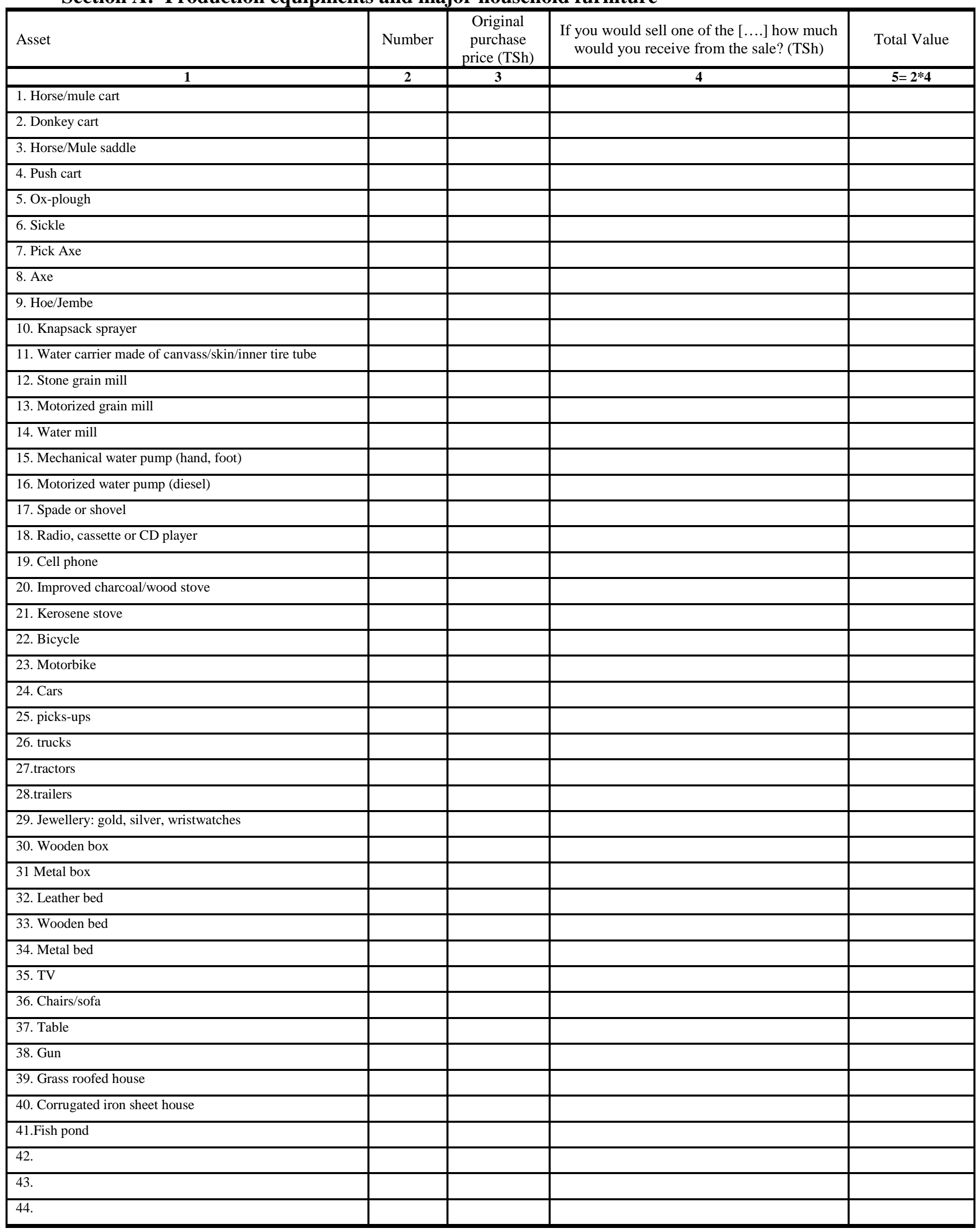


Section B: Land holding (acres) during the 2008/2009 cropping year (last cropping year)

\begin{tabular}{|l|c|c|c|c|}
\hline \multirow{2}{*}{ Land category } & \multicolumn{2}{|c|}{ Short rain season } & \multicolumn{2}{c|}{ Long rain season } \\
\cline { 2 - 5 } & Cultivated & $\begin{array}{c}\text { Uncultivated (e.g. } \\
\text { grazing, homestead } \\
\text { etc) }\end{array}$ & Cultivated & $\begin{array}{c}\text { Uncultivated (e.g. } \\
\text { grazing, } \\
\text { homestead etc) }\end{array}$ \\
\hline 1. Own land used (A) & & & & 3 \\
\hline 2. Rented in land (B) & & & & \\
\hline 3. Rented out land (C) & & & & \\
\hline 4. Borrowed in land (D) & & & & \\
\hline 5. Borrowed out land (E) & & & & \\
\hline 6. Total owned land (A+C+E) & & & & \\
\hline 7. Total operated land (A+B+D) & & & & \\
\hline 8. Bought land during long rain season & & & & \\
\hline 9. Sold land during long rain season & & & & \\
\hline
\end{tabular}

Total owned land 5 years ago $(2004 / 2005)$ - (acres) 
PART 5. IMPROVED CROP* VARIETY KNOWLEDGE AND ADOPTION

Section A. Crop variety knowledge, sources of information and seed, adoption and disadoption

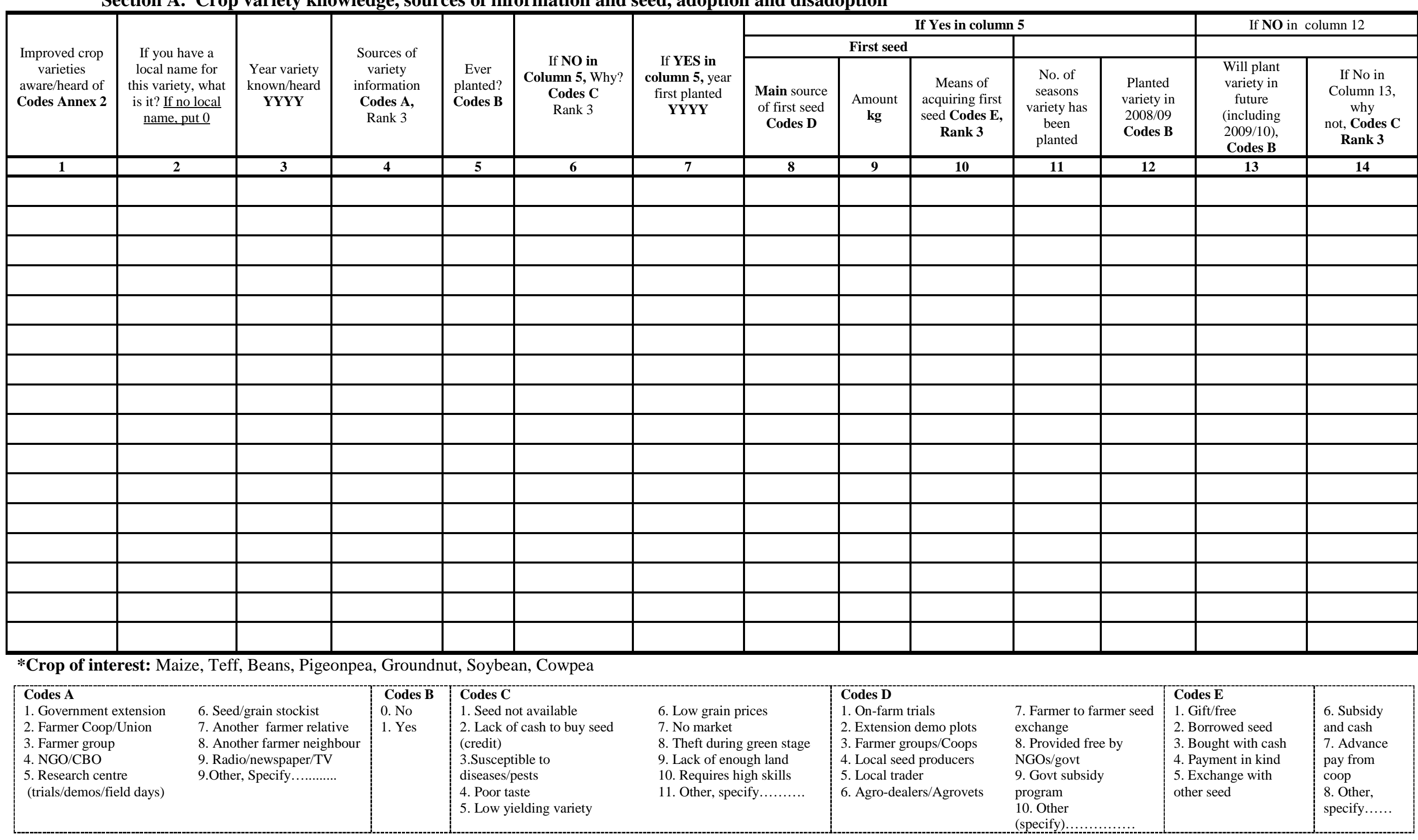


Section B: Maize variety characteristics grown during 2008/2009 and in the past [main local variety first]

\begin{tabular}{|c|c|c|c|c|c|c|c|c|c|c|}
\hline \multirow[t]{2}{*}{ Characteristics } & \multicolumn{10}{|c|}{ Maize varieties (main local variety first column, Codes in Annex 2) } \\
\hline & $1 \ldots .$. & $2 \ldots \ldots$ & $3 \ldots . .$. & $4 \ldots . .$. & $5 \ldots . .$. & $6 \ldots . .$. & $7 \ldots \ldots$ & $8 \ldots . .$. & $9 . \ldots .$. & $10 \ldots . .$. \\
\hline 1 & 2 & 3 & 4 & 5 & 6 & 7 & 8 & 9 & 10 & 11 \\
\hline \multicolumn{11}{|c|}{$\begin{array}{l}\text { Variety type according to farmer } \\
\text { (1=OPV; } 2=\text { Hybrid; 3=don’t know) }\end{array}$} \\
\hline \multicolumn{11}{|l|}{ Agronomic } \\
\hline \multicolumn{11}{|l|}{ 1.Grain yield } \\
\hline \multicolumn{11}{|l|}{ 2. Stover (crop residue) yield } \\
\hline \multicolumn{11}{|c|}{ 3. Palatability of Stover to livestock } \\
\hline \multicolumn{11}{|c|}{ 4. Drought tolerance } \\
\hline \multicolumn{11}{|l|}{ 5. Water-logging tolerance } \\
\hline \multicolumn{11}{|l|}{ 6. Disease tolerance } \\
\hline \multicolumn{11}{|l|}{ 7. Pest tolerance } \\
\hline \multicolumn{11}{|l|}{ 8. Early maturity } \\
\hline \multicolumn{11}{|l|}{ 9. Uniformity in maturity } \\
\hline \multicolumn{11}{|l|}{ 10. Grain size } \\
\hline \multicolumn{11}{|l|}{ 11. Cob Size } \\
\hline \multicolumn{11}{|l|}{ 12. Labour input saving } \\
\hline \multicolumn{11}{|l|}{ 13. Other inputs saving } \\
\hline \multicolumn{11}{|l|}{ Market and economics } \\
\hline \multicolumn{11}{|l|}{ 14. Marketability (demand) } \\
\hline \multicolumn{11}{|l|}{ 15. Grain colour } \\
\hline \multicolumn{11}{|l|}{ 16. Output (grain) price } \\
\hline \multicolumn{11}{|l|}{ Cooking \& utilization } \\
\hline \multicolumn{11}{|l|}{ 18. Storability } \\
\hline \multicolumn{11}{|l|}{ 19. Cooking time (Ugali) } \\
\hline \multicolumn{11}{|l|}{ 20. Taste } \\
\hline \multicolumn{11}{|l|}{ 21. Nutritional value } \\
\hline 22. Overall variety score & & & & & & & & & & \\
\hline
\end{tabular}

Codes A 1. Very poor, 2. Poor, 3. Average 4. Good, 5. Very Good

Section C: Beans varieties characteristics grown during 2008/2009 and in the past [main local variety first]

\begin{tabular}{|c|c|c|c|c|c|c|c|c|c|c|}
\hline \multirow[t]{2}{*}{ Characteristics } & \multicolumn{10}{|c|}{ Beans varieties (main local variety first column, Codes in Annex 2) } \\
\hline & $1 \ldots .$. & $2 \ldots \ldots$ & $3 \ldots . .$. & $4 \ldots . .$. & $5 \ldots . .$. & $6 \ldots . .$. & $7 \ldots . .$. & $8 \ldots .$. & $9 . \ldots .$. & $10 \ldots . .$. \\
\hline 1 & 2 & 3 & 4 & 5 & 6 & 7 & $\mathbf{8}$ & 9 & 10 & 11 \\
\hline \multicolumn{11}{|l|}{ Agronomic } \\
\hline \multicolumn{11}{|l|}{ 1. Grain yield } \\
\hline \multicolumn{11}{|c|}{ 2. Stover (crop residue) yield } \\
\hline \multicolumn{11}{|c|}{ 3. Palatability of Stover to livestock } \\
\hline \multicolumn{11}{|c|}{ 4. Drought tolerance } \\
\hline \multicolumn{11}{|l|}{ 5. Water-logging tolerance } \\
\hline \multicolumn{11}{|l|}{ 6. Disease tolerance } \\
\hline \multirow{2}{*}{\multicolumn{11}{|c|}{$\begin{array}{l}\text { 7. Pest tolerance } \\
8 . \text { Early maturity }\end{array}$}} \\
\hline \multirow{2}{*}{\multicolumn{11}{|c|}{ 8. Early maturity }} \\
\hline \multirow{2}{*}{\multicolumn{11}{|c|}{$\begin{array}{l}\text { 9. Uniformity in maturity } \\
10 \text { Grain size }\end{array}$}} \\
\hline & & & & & & & & & & \\
\hline \multicolumn{11}{|l|}{ 11. Labour input saving } \\
\hline \multicolumn{11}{|l|}{ 12. Other inputs saving } \\
\hline \multicolumn{11}{|l|}{ Market and economics } \\
\hline \multicolumn{11}{|l|}{ 13. Marketability (demand) } \\
\hline \multirow{2}{*}{\multicolumn{11}{|c|}{ 14. Grain colour }} \\
\hline 15. Output (grain) price & & & & & & & & & & \\
\hline \multicolumn{11}{|l|}{ Cooking \& utilization } \\
\hline \multicolumn{11}{|l|}{ 17. Storability } \\
\hline \multicolumn{11}{|l|}{ 18. Cooking time } \\
\hline \multicolumn{11}{|l|}{ 19. Taste } \\
\hline 20. Overall variety score & & & & & & & & & & \\
\hline
\end{tabular}


Section D: Pigeonpea varieties characteristics grown during 2008/2009 and in the past [main local variety first]

\begin{tabular}{|c|c|c|c|c|c|c|c|c|c|c|}
\hline \multirow[t]{2}{*}{ Characteristics } & \multicolumn{10}{|c|}{ Pigeonpea varieties (main local variety first column, Codes in Annex 2) } \\
\hline & $1 \ldots .$. & $2 \ldots . .$. & $3 \ldots . .$. & $4 \ldots . .$. & $5 \ldots . .$. & $6 \ldots . .$. & $7 \ldots . .$. & $8 \ldots . .$. & $9 . \ldots .$. & $10 \ldots . .$. \\
\hline 1 & 2 & 3 & 4 & 5 & 6 & 7 & 8 & 9 & 10 & 11 \\
\hline \multicolumn{11}{|l|}{ Agronomic } \\
\hline \multicolumn{11}{|l|}{ 1. Grain yield } \\
\hline \multicolumn{11}{|c|}{ 2. Stover (crop residue) yield } \\
\hline \multicolumn{11}{|c|}{ 3. Palatability of Stover to livestock } \\
\hline \multirow{2}{*}{\multicolumn{11}{|c|}{ 4. Drought tolerance }} \\
\hline \multicolumn{6}{|l|}{ 5. Water-logging tolerance } & & & & & \\
\hline \multirow{2}{*}{\multicolumn{11}{|c|}{$\begin{array}{l}\text { 6. Disease tolerance } \\
\text { 7. Pest tolerance }\end{array}$}} \\
\hline 7. Pest tolerance & & & & & & & & & & \\
\hline \multicolumn{11}{|l|}{ 8. Early maturity } \\
\hline \multicolumn{11}{|l|}{ 9. Uniformity in maturity } \\
\hline \multicolumn{11}{|l|}{ 10. Grain size } \\
\hline \multirow{2}{*}{\multicolumn{11}{|c|}{$\begin{array}{l}\text { 11. Labour input saving } \\
\text { 12. Other inputs saving }\end{array}$}} \\
\hline & & & & & & & & & & \\
\hline \multicolumn{11}{|l|}{ Market and economics } \\
\hline \multicolumn{11}{|l|}{ 13. Marketability (demand) } \\
\hline \multicolumn{11}{|l|}{ 14. Grain colour } \\
\hline \multicolumn{11}{|l|}{ 15. Output (grain) price } \\
\hline \multicolumn{11}{|l|}{ Cooking \& utilization } \\
\hline \multicolumn{11}{|l|}{$\begin{array}{l}\text { 17. Storability } \\
18 . \text { Cooking time }\end{array}$} \\
\hline 18. Cooking time & & & & & & & & & & \\
\hline \multicolumn{11}{|l|}{ 19. Taste } \\
\hline 20. Overall variety score & & & & & & & & & & \\
\hline
\end{tabular}

Codes A 1. Very poor, 2. Poor, 3.Average, 4. Good, 5. Very Good

Section E: .......... varieties (specify) characteristics grown during 2008/2009 and in the past [main local variety first]

\begin{tabular}{|c|c|c|c|c|c|c|c|c|c|c|}
\hline \multirow[t]{2}{*}{ Characteristics } & \multicolumn{10}{|c|}{ Other SIMLESA legume varieties (main local variety first column, Codes in Annex 2) } \\
\hline & $1 \ldots .$. & $2 \ldots \ldots$ & $3 \ldots . .$. & $4 \ldots \ldots$ & $5 \ldots \ldots$ & $6 \ldots . .$. & $7 \ldots \ldots$ & $8 \ldots \ldots$ & $9 \ldots \ldots$ & $10 \ldots . .$. \\
\hline 1 & 2 & 3 & 4 & 5 & 6 & 7 & 8 & 9 & 10 & 11 \\
\hline \multicolumn{11}{|l|}{ Agronomic } \\
\hline \multicolumn{11}{|l|}{ 1. Grain yield } \\
\hline \multicolumn{11}{|c|}{ 2. Stover (crop residue) yield } \\
\hline \multirow{2}{*}{\multicolumn{11}{|c|}{ 3. Palatability of Stover to livestock }} \\
\hline \multicolumn{5}{|c|}{ 4. Drought tolerance } & & & & & & \\
\hline \multirow{2}{*}{\multicolumn{11}{|c|}{ 5. Water-logging tolerance }} \\
\hline & & & & & & & & & & \\
\hline \multicolumn{11}{|l|}{ 7. Pest tolerance } \\
\hline \multicolumn{11}{|l|}{ 8. Early maturity } \\
\hline \multicolumn{11}{|l|}{ 9. Uniformity in maturity } \\
\hline \multicolumn{11}{|l|}{ 10. Grain size } \\
\hline \multirow{2}{*}{\multicolumn{11}{|c|}{$\begin{array}{l}\text { 11. Labour input saving } \\
\text { 12. Other inputs saving }\end{array}$}} \\
\hline & & & & & & & & & & \\
\hline \multicolumn{11}{|l|}{ Market and economics } \\
\hline \multicolumn{11}{|l|}{ 13. Marketability (demand) } \\
\hline \multicolumn{11}{|l|}{ 14. Grain colour } \\
\hline \multicolumn{11}{|l|}{ 15. Output (grain) price } \\
\hline \multicolumn{11}{|l|}{ Cooking \& utilization } \\
\hline \multicolumn{11}{|l|}{ 17. Storability } \\
\hline \multicolumn{11}{|l|}{ 18. Cooking time } \\
\hline \multicolumn{11}{|l|}{ 19. Taste } \\
\hline 20. Overall variety score & & & & & & & & & & \\
\hline
\end{tabular}


Section F: Main sources and quantity of seed for Maize, Teff, Beans, Pigeonpea, Groundnut, Soybean, Cowpea and other major legumes grown last cropping year $(2008 / 2009)$

\begin{tabular}{|c|c|c|c|c|c|c|c|c|c|c|c|}
\hline \multirow{3}{*}{$\begin{array}{l}\text { Season } \\
\text { Codes } \\
\text { A }\end{array}$} & \multirow{3}{*}{$\begin{array}{l}\text { Crop } \\
\text { Codes (See } \\
\text { attached } \\
\text { Annex 1) }\end{array}$} & \multirow{3}{*}{$\begin{array}{l}\text { Crop } \\
\text { variety } \\
\text { Codes } \\
\text { (See } \\
\text { attached } \\
\text { Annex 2) }\end{array}$} & \multirow{3}{*}{$\begin{array}{l}\text { Total amount } \\
\text { of seed }(\mathrm{kg})\end{array}$} & \multicolumn{8}{|c|}{ Quantity of seed and sources } \\
\hline & & & & \multicolumn{2}{|c|}{ Source 1} & \multicolumn{2}{|c|}{ Source 2} & \multicolumn{2}{|c|}{ Source 3} & \multicolumn{2}{|c|}{ Source 4} \\
\hline & & & & Codes B & $\underset{(\mathrm{kg})}{\text { Amount }}$ & Codes B & $\underset{(\mathrm{kg})}{\text { Amount }}$ & Codes B & $\underset{(\mathrm{kg})}{\text { Amount }}$ & Codes B & $\underset{(\mathrm{kg})}{\text { Amount }}$ \\
\hline 1 & 2 & 3 & 4 & 5 & 6 & 7 & 8 & 9 & 10 & 11 & 12 \\
\hline & & & & & & & & & & & \\
\hline & & & & & & & & & & & \\
\hline & & & & & & & & & & & \\
\hline & & & & & & & & & & & \\
\hline & & & & & & & & & & & \\
\hline & & & & & & & & & & & \\
\hline & & & & & & & & & & & \\
\hline & & & & & & & & & & & \\
\hline & & & & & & & & & & & \\
\hline & & & & & & & & & & & \\
\hline & & & & & & & & & & & \\
\hline & & & & & & & & & & & \\
\hline & & & & & & & & & & & \\
\hline & & & & & & & & & & & \\
\hline & & & & & & & & & & & \\
\hline & & & & & & & & & & & \\
\hline & & & & & & & & & & & \\
\hline & & & & & & & & & & & \\
\hline & & & & & & & & & & & \\
\hline & & & & & & & & & & & \\
\hline & & & & & & & & & & & \\
\hline & & & & & & & & & & & \\
\hline & & & & & & & & & & & \\
\hline & & & & & & & & & & & \\
\hline & & & & & & & & & & & \\
\hline $\begin{array}{l}\text { Codes A } \\
\text { 1. Mino } \\
\text { 2. Majo }\end{array}$ & short rain & $\begin{array}{l}\text { Codes B } \\
\text { 1. Own sav } \\
\text { 2. Gift fron } \\
\text { 3. Farmer t } \\
\text { 4. On-farm }\end{array}$ & $\begin{array}{l}\text { amily/neighbor } \\
\text { farmer seed exchang } \\
\text { ials }\end{array}$ & & $\begin{array}{l}\text { xtension dem } \\
\text { armer groups/ } \\
\text { ocal seed proc } \\
\text { ocal trader }\end{array}$ & $\begin{array}{l}\text { plots } \\
\text { Coops } \\
\text { ucers }\end{array}$ & $\begin{array}{l}\text { 9. Agro-dealer } \\
\text { 10. Bought fro } \\
\text { 11. Provided fr } \\
\text { 12. Govt subsis }\end{array}$ & $\begin{array}{l}\text { ggrovets } \\
\text { seed company } \\
\text { by NGOs/gov } \\
\text { program }\end{array}$ & & Other (specify & .......... \\
\hline
\end{tabular}




\section{PART 6. CROP PRODUCTION}

Section A. Plot characteristics, investment and input use

Definitions: A plot (Shamba) is a piece of land physically separated from others; a subplot (Kijishamba) is a subunit of a plot.

If more than one crop is grown on a plot (that is, on different subplots), repeat the plot code in next row and use subplot code.

If the (sub)plot is intercropped, use same row and separate the different intercrops by comma. Consider only 3 main intercrops if more than 3 on a (sub)plot.

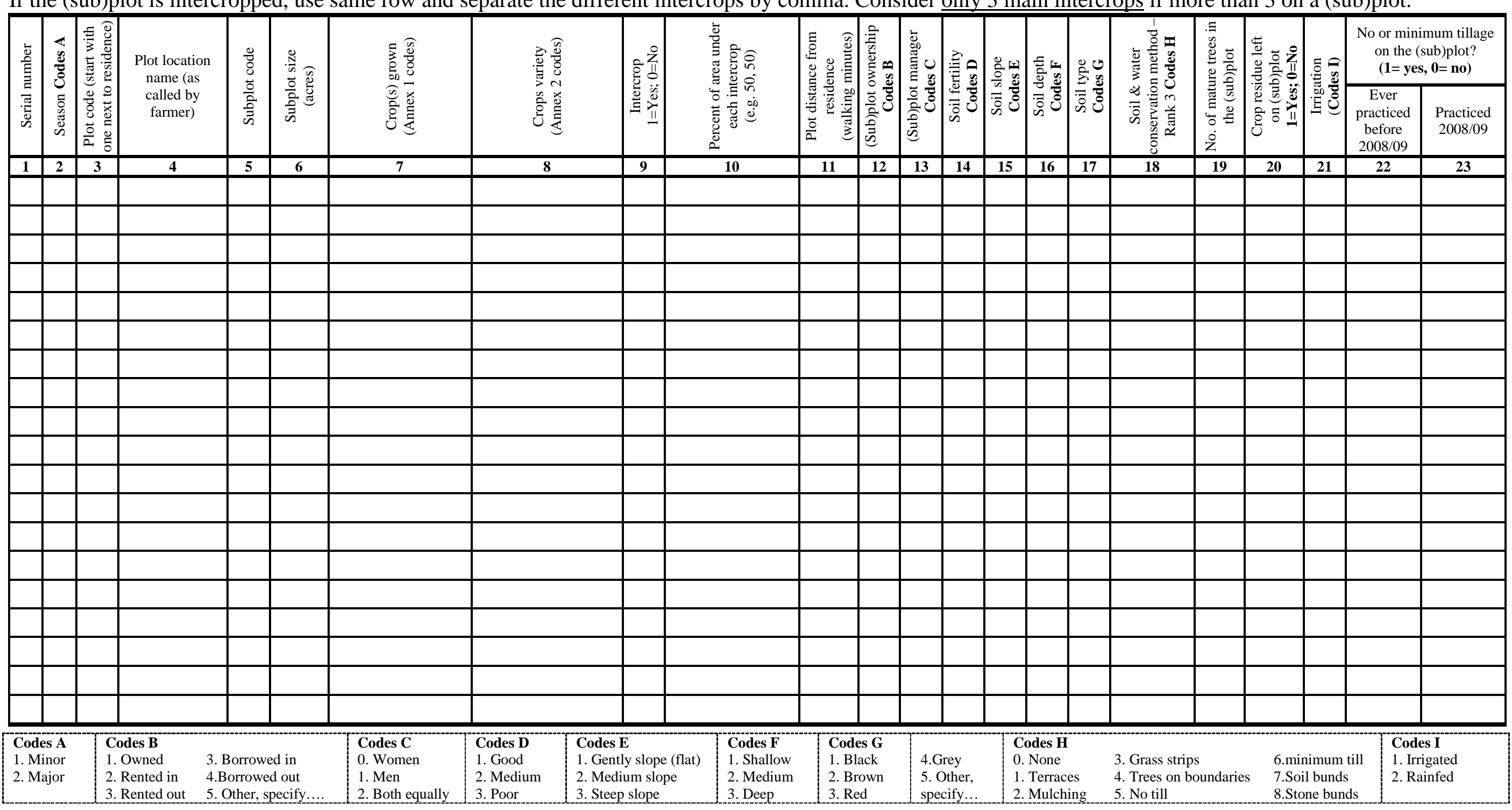


Section B: Input use

(Serial number, plot code, sub-plot code, and crop(s) grown in this Section should be in exactly the same order as in Section A above)

\begin{tabular}{|c|c|c|c|c|c|c|c|c|c|c|c|c|c|c|c|c|c|c|c|}
\hline \multirow{3}{*}{ 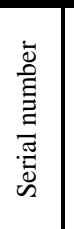 } & \multirow{3}{*}{ 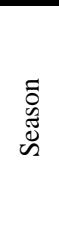 } & \multirow{3}{*}{$\begin{array}{l}\frac{\pi}{0} \\
\frac{0}{0} \\
\frac{0}{2}\end{array}$} & \multirow{3}{*}{ 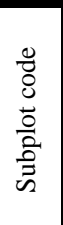 } & \multirow{3}{*}{ 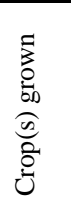 } & \multirow{3}{*}{ 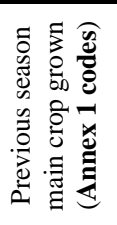 } & \multicolumn{4}{|c|}{ Fertilizer (If not used, put Zero) } & \multicolumn{5}{|c|}{ Seed (if intercropped, separate by comma) } & \multicolumn{3}{|c|}{ Manure (dry equivalent) } & \multicolumn{2}{|c|}{ Herbicides } \\
\hline & & & & & & \multirow{2}{*}{ 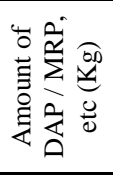 } & \multirow[b]{2}{*}{$\begin{array}{c}\text { Total } \\
\text { cost } \\
\text { (TSh) }\end{array}$} & \multirow[b]{2}{*}{$\begin{array}{c}\text { Amount } \\
\text { of CAN/ } \\
\text { Urea etc } \\
(\mathrm{Kg})\end{array}$} & \multirow[b]{2}{*}{$\begin{array}{l}\text { Total cost } \\
\text { (TSh) }\end{array}$} & \multirow[b]{2}{*}{$\begin{array}{l}\text { Main seed } \\
\text { source } \\
\text { (Codes A) }\end{array}$} & \multirow[b]{2}{*}{$\begin{array}{l}\text { Amount of } \\
\text { own saved/ } \\
\text { gift (kg) }\end{array}$} & \multirow{2}{*}{$\begin{array}{c}\text { Number } \\
\text { of seasons } \\
\text { own } \\
\text { saved/gift } \\
\text { recycled }\end{array}$} & \multicolumn{2}{|c|}{ Bought } & \multirow{2}{*}{$\begin{array}{l}\text { own } \\
\mathrm{kg}\end{array}$} & \multicolumn{2}{|c|}{ Bought } & \multirow[b]{2}{*}{ litres } & \multirow[b]{2}{*}{$\begin{array}{l}\text { Total } \\
\text { cost } \\
\text { (TSh) }\end{array}$} \\
\hline & & & & & & & & & & & & & $\begin{array}{c}\text { Amount } \\
(\mathrm{kg})\end{array}$ & Total cost (TSh) & & $\mathrm{kg}$ & $\begin{array}{c}\text { Total } \\
\text { cost } \\
\text { (TSh) }\end{array}$ & & \\
\hline & & & & & & & & & & & & & & & & & & & \\
\hline & & & & & & & & & & & & & & & & & & & \\
\hline & & & & & & & & & & & & & & & & & & & \\
\hline & & & & & & & & & & & & & & & & & & & \\
\hline & & & & & & & & & & & & & & & & & & & \\
\hline & & & & & & & & & & & & & & & & & & & \\
\hline & & & & & & & & & & & & & & & & & & & \\
\hline & & & & & & & & & & & & & & & & & & & \\
\hline & & & & & & & & & & & & & & & & & & & \\
\hline & & & & & & & & & & & & & & & & & & & \\
\hline & & & & & & & & & & & & & & & & & & & \\
\hline & & & & & & & & & & & & & & & & & & & \\
\hline & & & & & & & & & & & & & & & & & & & \\
\hline & & & & & & & & & & & & & & & & & & & \\
\hline & & & & & & & & & & & & & & & & & & & \\
\hline & & & & & & & & & & & & & & & & & & & \\
\hline & & & & & & & & & & & & & & & & & & & \\
\hline & & $\begin{array}{l}\text { odes } \\
\text { Own } \\
\text { Gift } \\
\text { Farm } \\
\text { On-f } \\
\end{array}$ & $\begin{array}{l}\text { saved } \\
\text { sam fa } \\
\text { re to fo } \\
\text { rm trii }\end{array}$ & & hange & & $\begin{array}{l}\text { xtension } \\
\text { armer gro } \\
\text { ocal seed } \\
\text { ocal trade }\end{array}$ & $\begin{array}{l}\text { mo plots } \\
\text { s/Coops } \\
\text { oducers }\end{array}$ & $\begin{array}{l}\text { 9. Ag } \\
\text { 10. } \\
\text { 11. } \mathrm{P} \\
\text {-12. }\end{array}$ & $\begin{array}{l}\text {-dealers/agrove } \\
\text { ught from seed } \\
\text { vided free by N } \\
\text { vt subsidy prog }\end{array}$ & $\begin{array}{l}\text { mpany } \\
\text { Os/govt } \\
\text { n }\end{array}$ & 13. Ot & r (specify)... & & & & & & \\
\hline
\end{tabular}


Section C: Input use and crop harvested

(Serial number, plot code, sub-plot code, and crop(s) grown in this Section should be in exactly the same order as in Section A above)

\begin{tabular}{|c|c|c|c|c|c|c|c|c|c|c|c|c|c|c|c|c|c|c|c|c|c|c|}
\hline \multirow{3}{*}{ 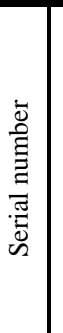 } & \multirow{3}{*}{ 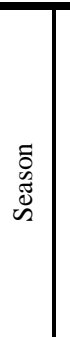 } & \multirow{3}{*}{$\begin{array}{l}\frac{0}{0} \\
0 \\
\frac{0}{2}\end{array}$} & \multirow{3}{*}{ 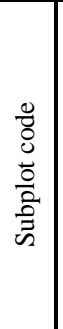 } & \multirow{3}{*}{$\begin{array}{l}\text { Crop(s) } \\
\text { grown }\end{array}$} & \multicolumn{2}{|c|}{ Pesticides } & \multirow{2}{*}{\multicolumn{2}{|c|}{ Oxen days }} & \multirow{2}{*}{\multicolumn{2}{|c|}{$\begin{array}{c}\text { Land } \\
\text { preparation } \\
\text { \& planting }\end{array}$}} & \multicolumn{7}{|c|}{$\begin{array}{l}\text { Total labour (family and hired) } \\
\text { Intercrops: record harvesting and threshing/shelling } \\
\text { separately (by comma) }\end{array}$} & \multirow{3}{*}{$\begin{array}{l}\text { Cost of } \\
\text { oxen } \\
\text { hired } \\
\text { (TSh) }\end{array}$} & \multirow{3}{*}{$\begin{array}{l}\text { Cost of } \\
\text { hired } \\
\text { labour } \\
\text { (TSh) }\end{array}$} & \multirow{3}{*}{ 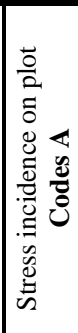 } & \multicolumn{2}{|c|}{$\begin{array}{l}\text { Total harvested per (sub)plot } \\
\text { Intercrops: separate by comma }\end{array}$} \\
\hline & & & & & \multirow[b]{2}{*}{$\stackrel{\mathscr{E}}{:}$} & \multirow{2}{*}{ 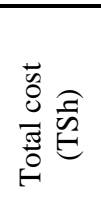 } & & & & & \multicolumn{3}{|c|}{ Weed control } & \multicolumn{2}{|c|}{ Harvesting } & \multicolumn{2}{|c|}{$\begin{array}{c}\text { Threshing or } \\
\text { shelling }\end{array}$} & & & & & \\
\hline & & & & & & & 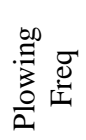 & 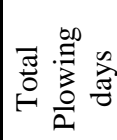 & $\frac{\pi}{\sqrt[\pi]{\pi}}$ & 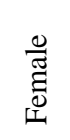 & 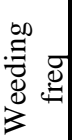 & $\frac{\frac{9}{\pi}}{\sum^{\pi}}$ & 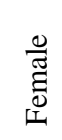 & $\sum_{\Sigma}^{\frac{\pi}{\pi}}$ & 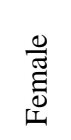 & $\sum_{\Sigma}^{\frac{\pi}{\pi}}$ & 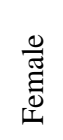 & & & & $\begin{array}{l}\text { Fresh or } \\
\text { green (kg) }\end{array}$ & Dry (kg) \\
\hline 1 & 2 & 3 & 4 & 5 & 6 & 7 & 8 & 9 & 11 & 12 & 13 & 14 & 15 & 16 & 17 & 18 & 19 & 20 & 21 & 22 & 23 & 24 \\
\hline & & & & & & & & & & & & & & & & & & & & & & \\
\hline & & & & & & & & & & & & & & & & & & & & & & \\
\hline & & & & & & & & & & & & & & & & & & & & & & \\
\hline & & & & & & & & & & & & & & & & & & & & & & \\
\hline & & & & & & & & & & & & & & & & & & & & & & \\
\hline & & & & & & & & & & & & & & & & & & & & & & \\
\hline & & & & & & & & & & & & & & & & & & & & & & \\
\hline & & & & & & & & & & & & & & & & & & & & & & \\
\hline & & & & & & & & & & & & & & & & & & & & & & \\
\hline & & & & & & & & & & & & & & & & & & & & & & \\
\hline & & & & & & & & & & & & & & & & & & & & & & \\
\hline & & & & & & & & & & & & & & & & & & & & & & \\
\hline & & & & & & & & & & & & & & & & & & & & & & \\
\hline & & & & & & & & & & & & & & & & & & & & & & \\
\hline & & & & & & & & & & & & & & & & & & & & & & \\
\hline & & & & & & & & & & & & & & & & & & & & & & \\
\hline & & & & & & & & & & & & & & & & & & & & & & \\
\hline & & & & & & & & & & & & & & & & & & & & & & \\
\hline & & & & & & & & & & & & & & & & & & & & & & \\
\hline
\end{tabular}

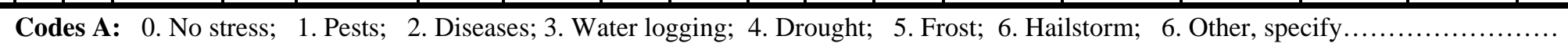


Section D: Utilization of crop produced and household food security

Different from Sections A-C: one row per crop and season (e.g. add production from all maize plots together for season 1)

\begin{tabular}{|c|c|c|c|c|c|c|c|c|c|c|c|c|c|}
\hline \multirow{3}{*}{$\begin{array}{l}\text { Crop } \\
\text { (From } \\
\text { section } \\
\text { C) }\end{array}$} & \multirow{3}{*}{$\begin{array}{l}\text { Season } \\
\text { (From } \\
\text { section } \\
\text { C) }\end{array}$} & \multirow{3}{*}{$\begin{array}{l}\text { Form } \\
\text { Codes A }\end{array}$} & \multirow{3}{*}{$\begin{array}{c}\text { Stock before } \\
\text { 2008/09 } \\
\text { harvest (kg) }\end{array}$} & \multirow{3}{*}{$\begin{array}{l}\text { Production of } \\
\text { 2008/09 } \\
\text { (last columns } \\
\text { of Section C) }\end{array}$} & \multirow{3}{*}{$\begin{array}{l}\text { Total available } \\
\text { stock after } \\
2008 / 09 \\
\text { harvest } \\
=\text { Column } 4+5\end{array}$} & \multicolumn{5}{|c|}{ From the total available stock after 2008/09 harvest (column 6).. } & \multirow{3}{*}{$\begin{array}{c}\text { Ending stock } \\
\text { (Stock before } \\
2009 / 10 \\
\text { harvest) }(\mathrm{kg})\end{array}$} & \multirow{2}{*}{\multicolumn{2}{|c|}{$\begin{array}{l}\text { If total available stock } \\
\text { of 2008/09 was not } \\
\text { sufficient for } \\
\text { consumption until } \\
\text { 2009/10 harvest: }\end{array}$}} \\
\hline & & & & & & \multirow{2}{*}{$\begin{array}{c}\text { Quantity } \\
\text { sold after } \\
2008 / 09 \\
\text { harvest } \\
(\mathrm{kg})\end{array}$} & \multirow{2}{*}{$\begin{array}{c}\text { In-kind payments } \\
\text { (labour, land \& } \\
\text { others) paid } \\
\text { during 2009/10 } \\
\text { cropping year } \\
\text { (kg) }\end{array}$} & \multirow{2}{*}{$\begin{array}{l}\text { Seed used } \\
\text { during } \\
2009 / 10 \\
\text { cropping } \\
\text { year }(\mathrm{kg})\end{array}$} & \multirow{2}{*}{$\begin{array}{l}\text { Gift, tithe, } \\
\text { donations } \\
\text { given out } \\
\text { during 2009/10 } \\
\text { cropping year } \\
(\mathrm{kg}) \\
\end{array}$} & \multirow{2}{*}{$\begin{array}{c}\text { Consumption } \\
\text { during } \\
2009 / 10 \\
\text { cropping year } \\
(\mathrm{kg})\end{array}$} & & & \\
\hline & & & & & & & & & & & & $\begin{array}{c}\text { Amount } \\
\text { bought (kg) }\end{array}$ & $\begin{array}{c}\text { Food } \\
\text { aid/gifts } \\
\text { received } \\
(\mathrm{kg})\end{array}$ \\
\hline 1 & 2 & 3 & 4 & 5 & 6 & 7 & 8 & 9 & 10 & 11 & $\begin{array}{c}12=6-7-8-9- \\
10-11\end{array}$ & 13 & 14 \\
\hline & & & & & & & & & & & & & \\
\hline & & & & & & & & & & & & & \\
\hline & & & & & & & & & & & & & \\
\hline & & & & & & & & & & & & & \\
\hline & & & & & & & & & & & & & \\
\hline & & & & & & & & & & & & & \\
\hline & & & & & & & & & & & & & \\
\hline & & & & & & & & & & & & & \\
\hline & & & & & & & & & & & & & \\
\hline & & & & & & & & & & & & & \\
\hline & & & & & & & & & & & & & \\
\hline & & & & & & & & & & & & & \\
\hline & & & & & & & & & & & & & \\
\hline & & & & & & & & & & & & & \\
\hline & & & & & & & & & & & & & \\
\hline & & & & & & & & & & & & & \\
\hline & & & & & & & & & & & & & \\
\hline & & & & & & & & & & & & & \\
\hline & & & & & & & & & & & & & \\
\hline
\end{tabular}

Codes A: 1. Fresh/green; 
Section E: Marketing of crops

Different from Sections A-D: one row per sale (different months, different buyers), per crop and per season

\begin{tabular}{|c|c|c|c|c|c|c|c|c|c|c|c|c|c|c|c|c|}
\hline $\begin{array}{l}\text { Crop } \\
\text { (From } \\
\text { Column } 1 \\
\text { of Section } \\
\text { D) }\end{array}$ & $\begin{array}{c}\text { Season } \\
\text { (From } \\
\text { Column } 2 \\
\text { of Section } \\
\text { D) }\end{array}$ & $\begin{array}{c}\text { Form } \\
\text { (From } \\
\text { Column } 3 \\
\text { of Section } \\
\text { D) }\end{array}$ & $\begin{array}{l}\text { Market } \\
\text { type } \\
\text { Codes } \\
\text { A }\end{array}$ & $\begin{array}{l}\text { Quantity } \\
\text { sold kg } \\
\text { (From } \\
\text { Column } 7 \text { of } \\
\text { Section D) }\end{array}$ & $\begin{array}{l}\text { Who } \\
\text { sold } \\
\text { Codes } \\
\text { B }\end{array}$ & $\begin{array}{l}\text { Price } \\
\text { (TSh } \\
\text { /kg) }\end{array}$ & $\begin{array}{c}\text { Montl } \\
\text { sold } \\
\text { Codes } \\
\text { C }\end{array}$ & $\begin{array}{l}\text { Period to } \\
\text { payment after } \\
\text { selling, weeks } \\
\text { (if immediate } \\
\text { write zero) }\end{array}$ & $\begin{array}{l}\text { Buyer } \\
\text { Codes } \\
\text { D }\end{array}$ & $\begin{array}{l}\text { Relation } \\
\text { to buyer } \\
\text { Codes E }\end{array}$ & $\begin{array}{l}\text { Quality } \\
\text { Codes F }\end{array}$ & $\begin{array}{c}\text { Sales tax } \\
\text { or } \\
\text { charges } \\
\text { (TSh) }\end{array}$ & $\begin{array}{l}\text { Time } \\
\text { taken to } \\
\text { sell crop } \\
\text { (minutes) }\end{array}$ & $\begin{array}{l}\text { Time } \\
\text { taken to } \\
\text { get to the } \\
\text { market } \\
\text { (minutes) }\end{array}$ & $\begin{array}{l}\text { Mode of } \\
\text { transport } \\
\text { Codes G }\end{array}$ & $\begin{array}{c}\text { Actual } \\
\text { transport } \\
\text { cost (TSh) }\end{array}$ \\
\hline 1 & 2 & 3 & 4 & 5 & 6 & 7 & 8 & 9 & 10 & 11 & 12 & 13 & 14 & \multirow[t]{2}{*}{15} & \multirow[t]{2}{*}{16} & \multirow[t]{2}{*}{17} \\
\hline & & & & & & & & & & & & & & & & \\
\hline & & & & & & & & & & & & & & & & \\
\hline & & & & & & & & & & & & & & & & \\
\hline & & & & & & & & & & & & & & & & \\
\hline & & & & & & & & & & & & & & & & \\
\hline & & & & & & & & & & & & & & & & \\
\hline & & & & & & & & & & & & & & & & \\
\hline & & & & & & & & & & & & & & & & \\
\hline & & & & & & & & & & & & & & & & \\
\hline & & & & & & & & & & & & & & & & \\
\hline & & & & & & & & & & & & & & & & \\
\hline & & & & & & & & & & & & & & & & \\
\hline & & & & & & & & & & & & & & & & \\
\hline & & & & & & & & & & & & & & & & \\
\hline & & & & & & & & & & & & & & & & \\
\hline & & & & & & & & & & & & & & & & \\
\hline & & & & & & & & & & & & & & & & \\
\hline & & & & & & & & & & & & & & & & \\
\hline $\begin{array}{l}\text { Codes A } \\
\text { 1. Farmgate } \\
\text { 2. Village mal } \\
\text { 3. Main/distri }\end{array}$ & ket & $\begin{array}{l}\text { Codes B } \\
0 . \text { Female } \\
\text { 1. Male }\end{array}$ & $\begin{array}{l}\text { Codes C- } \\
\text { 1. January } \\
\text { 2. February } \\
\text { 3. March } \\
\text { 4. April } \\
\text { 5. May } \\
\text { 6. June }\end{array}$ & $\begin{array}{l}\text { 7. July } \\
\text { 8. August } \\
\text { 9. September } \\
\text { 10. October } \\
\text { 11. November } \\
\text { 12. December }\end{array}$ & $\begin{array}{l}\text { Codes D } \\
\text { 1. Farme } \\
\text { 2. Farme } \\
\text { 3. Consu } \\
\text { 4. Rural } \\
\text { 5. Broke } \\
\text { 6. Rural }\end{array}$ & $\begin{array}{l}\text { group } \\
\text { Union or Cc } \\
\text { aer or other } \\
\text { ssembler } \\
\text { middlemen } \\
\text { rain trader }\end{array}$ & $\begin{array}{l}\text { op } \\
\text { armer } \\
\end{array}$ & $\begin{array}{l}\text { 7. Rural wholesaler } \\
\text { 8. Urban wholesaler } \\
\text { 9. Urban grain trader } \\
\text { 10. Exporter, } \\
\text { 11. Other, specify....... }\end{array}$ & $\begin{array}{l}\text { Coc } \\
\text { 1. I } \\
\text { 2. I } \\
\text { 3. } \mathrm{R} \\
\text { 4. I } \\
\text { 5. N } \\
\text { 6. }\end{array}$ & $\begin{array}{l}\text { s E } \\
\text { relation but } \\
\text { relation but } \\
\text { lative } \\
\text { end } \\
\text { oney lender } \\
\text { her, specify.. }\end{array}$ & $\begin{array}{l}\text { to long time } \\
\text { long term bu }\end{array}$ & $\begin{array}{l}\text { buyer } \\
\text { er }\end{array}$ & $\begin{array}{l}\text { Codes } \mathbf{F} \\
\text { 1. Below average } \\
\text { 2. Fair and Average } \\
\text { 3. Above average }\end{array}$ & $\begin{array}{l}\text { Codes G } \\
\text { 1. Bicyc } \\
\text { 2. Hired } \\
\text { 3. Public } \\
\text { 4. Donk } \\
\text { 5. Oxen// } \\
\text { 6. Back/ } \\
\text { 7. Other }\end{array}$ & $\begin{array}{l}\text { uck } \\
\text { ransport } \\
\text { orse cart } \\
\text { ead load } \\
\text { iecify..... }\end{array}$ & \\
\hline
\end{tabular}


Section F: Percent utilization of crop residues of $2008 / 09$ season (\%)

Same order of crops and seasons as section $D$. Note that percentages need to add up to $100 \%$ for every row.

\begin{tabular}{|c|c|c|c|c|c|c|c|c|c|}
\hline $\begin{array}{l}\text { Crop (same order } \\
\text { as in section C } \\
\text { above) }\end{array}$ & $\begin{array}{c}\text { Season } \\
\text { (From Column } 2 \\
\text { of Section D) }\end{array}$ & $\begin{array}{l}\text { Total production } \\
\text { of crop residues } \\
(\mathrm{kg})\end{array}$ & $\begin{array}{l}\text { Burnt in the } \\
\text { field (\%) }\end{array}$ & $\begin{array}{c}\text { Used as } \\
\text { firewood (\%) }\end{array}$ & $\begin{array}{l}\text { Left on land } \\
\text { for soil fertility } \\
\text { (\%) }\end{array}$ & $\begin{array}{c}\text { Feed for } \\
\text { livestock (\%) }\end{array}$ & $\begin{array}{c}\text { Used for } \\
\text { construction } \\
(\%)\end{array}$ & Sold (\%) & Other uses (\%) \\
\hline 1 & 2 & $\begin{array}{c}3 \\
\end{array}$ & 4 & 5 & 6 & 7 & 8 & 9 & 10 \\
\hline & & & & & & & & & \\
\hline & & & & & & & & & \\
\hline & & & & & & & & & \\
\hline & & & & & & & & & \\
\hline & & & & & & & & & \\
\hline & & & & & & & & & \\
\hline & & & & & & & & & \\
\hline & & & & & & & & & \\
\hline & & & & & & & & & \\
\hline & & & & & & & & & \\
\hline & & & & & & & & & \\
\hline & & & & & & & & & \\
\hline & & & & & & & & & \\
\hline & & & & & & & & & \\
\hline & & & & & & & & & \\
\hline & & & & & & & & & \\
\hline & & & & & & & & & \\
\hline & & & & & & & & & \\
\hline & & & & & & & & & \\
\hline & & & & & & & & & \\
\hline & & & & & & & & & \\
\hline & & & & & & & & & \\
\hline & & & & & & & & & \\
\hline
\end{tabular}


Section G: Grain storage practices of $2008 / 09$ season

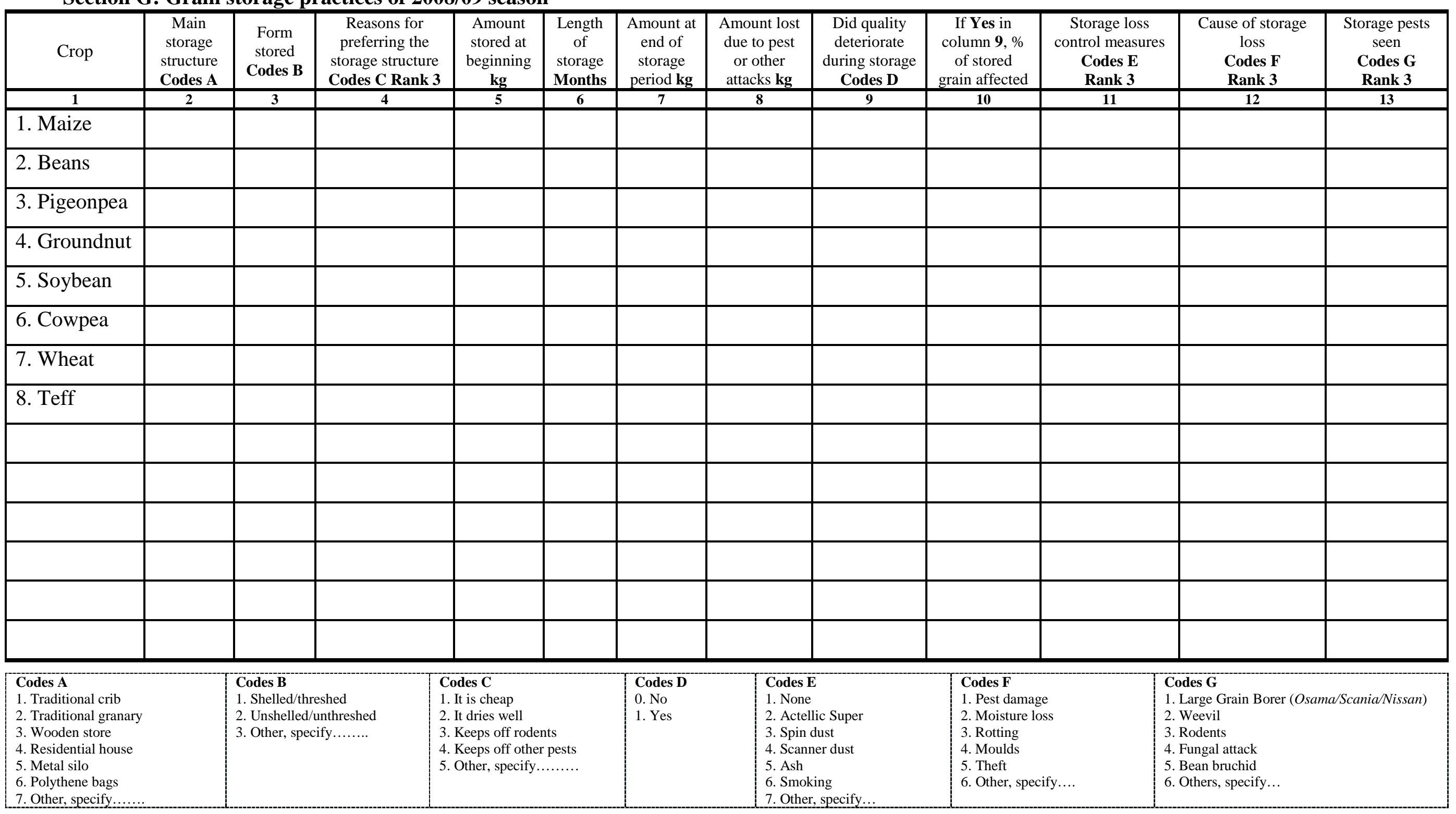


PART 7: LIVESTOCK PRODUCTION AND MARKETING

Section A: Livestock production activities during 2008/09 cropping year

\begin{tabular}{|c|c|c|c|c|c|c|c|c|c|c|c|}
\hline \multirow[b]{2}{*}{ Livestock type } & \multirow{2}{*}{$\begin{array}{c}\text { Number of livestock at } \\
\text { end of 2008/09 cropping } \\
\text { season (including bought } \\
\text { ones) }\end{array}$} & \multirow{2}{*}{$\begin{array}{l}\text { If you would sell one of } \\
\text { the [...], how much } \\
\text { would you receive from } \\
\text { the sale? (TSh) }\end{array}$} & \multirow{2}{*}{$\begin{array}{l}\text { Average } \\
\text { total days } \\
\text { milked per } \\
\text { animal }\end{array}$} & \multirow{2}{*}{$\begin{array}{c}\text { Average } \\
\text { daily milk } \\
\text { yield per } \\
\text { animal } \\
\text { (liters) }\end{array}$} & \multirow{2}{*}{$\begin{array}{l}\text { Total milk production } \\
\text { (liters) \& honey } \\
\text { production per beehive } \\
(\mathrm{kg}) \underline{\text { Calculate: }}\end{array}$} & \multicolumn{6}{|c|}{ Total Cost of Production (TSh) } \\
\hline & & & & & & Fodder & Labour & $\begin{array}{l}\text { Veterinary } \\
\text { care }\end{array}$ & $\begin{array}{c}\text { Artificial } \\
\text { insemination }\end{array}$ & Salt & Others \\
\hline 1 & 2 & 3 & 4 & 5 & $6=2 * 4 * 5$ & 7 & 8 & 9 & 10 & 11 & 12 \\
\hline \multicolumn{12}{|l|}{ Cattle } \\
\hline \multicolumn{12}{|l|}{ 1. Indigenous milking cows } \\
\hline \multicolumn{12}{|l|}{ 2. Cross-bred milking cows } \\
\hline \multicolumn{12}{|l|}{ 3.Exotic milking cows } \\
\hline \multicolumn{12}{|c|}{ 4. Non milking cows (mature) } \\
\hline \multicolumn{12}{|c|}{ 5. Trained oxen for ploughing } \\
\hline \multicolumn{12}{|c|}{ 6. Bulls } \\
\hline \multicolumn{12}{|l|}{ 7. Heifers } \\
\hline \multicolumn{12}{|l|}{ 8. Calves } \\
\hline \multicolumn{12}{|l|}{ Goats } \\
\hline \multicolumn{12}{|l|}{ 9. Mature milking goats } \\
\hline \multicolumn{12}{|c|}{ 10. Other mature female goats } \\
\hline \multicolumn{12}{|c|}{ 11. Young male goats } \\
\hline \multicolumn{12}{|l|}{ 12.Young female goats } \\
\hline \multicolumn{12}{|l|}{ Sheep } \\
\hline \multicolumn{12}{|l|}{ 13. Mature female sheep } \\
\hline \multicolumn{12}{|l|}{ 14. Mature male sheep } \\
\hline \multicolumn{12}{|l|}{ 15. Young female sheep } \\
\hline 16. Young male sheep & & & & & & & & & & & \\
\hline Other livestock & & & & & & & & & & & \\
\hline 17. Mature trained donkeys & & & & & & & & & & & \\
\hline 18. Young donkeys & & & & & & & & & & & \\
\hline 19. Horses & & & & & & & & & & & \\
\hline 20. Mules & & & & & & & & & & & \\
\hline 21. Mature chicken & & & & & & & & & & & \\
\hline 22. Local Bee hives & & & & & & & & & & & \\
\hline 23.Modern Bee hives & & & & & & & & & & & \\
\hline 24.Pigs, mature & & & & & & & & & & & \\
\hline 25.Pigs, young & & & & & & & & & & & \\
\hline 26.Turkeys, mature & & & & & & & & & & & \\
\hline 27.Guinea fowls, mature & & & & & & & & & & & \\
\hline 28.Ducks, mature & & & & & & & & & & & \\
\hline 29.Rabbit, mature & & & & & & & & & & & \\
\hline 30. & & & & & & & & & & & \\
\hline
\end{tabular}


Section B: Livestock and livestock products selling and buying activities during 2008/09

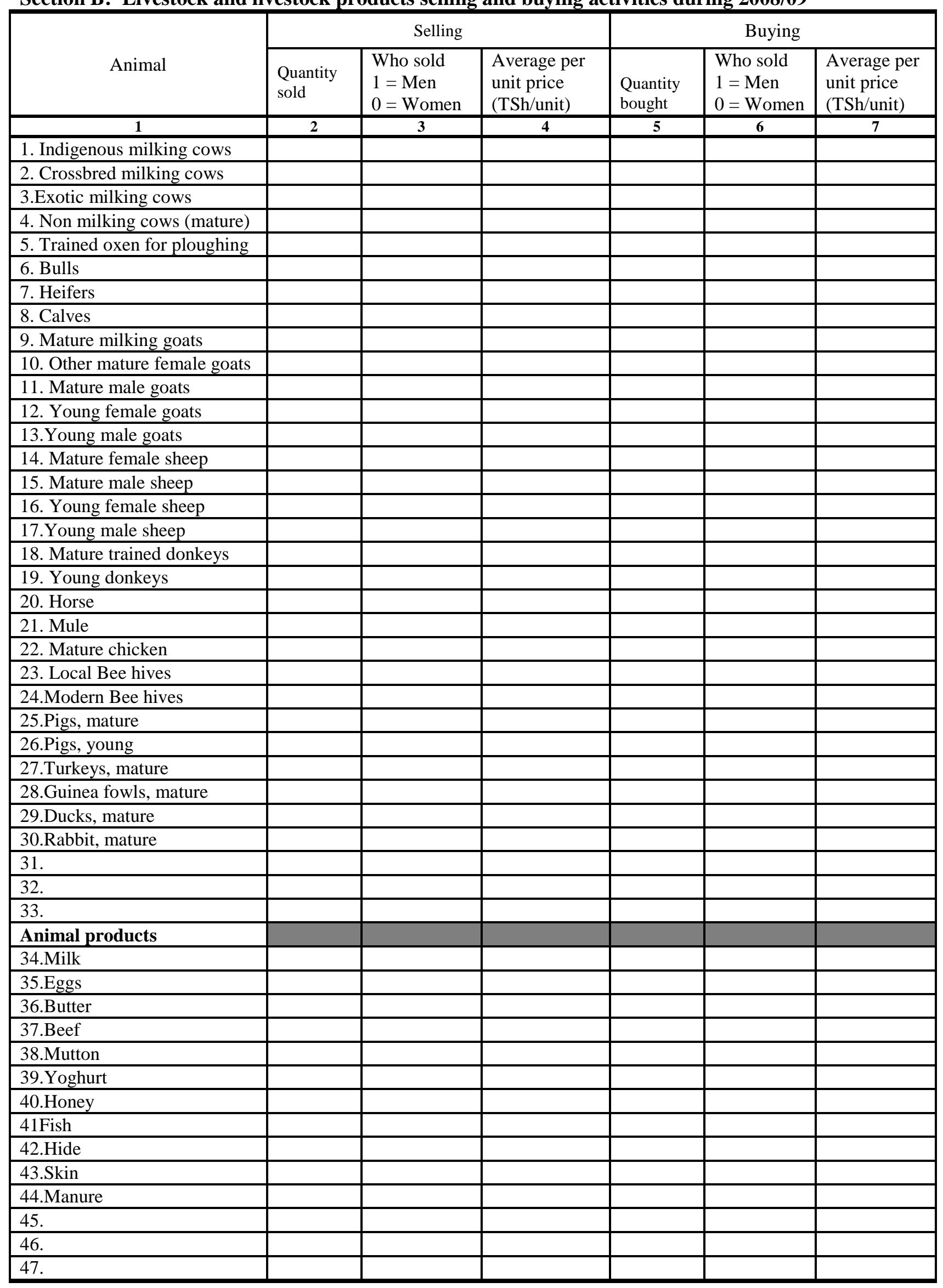


PART 8: TRANSFER AND OTHER SOURCES OF INCOME DURING 2008/09 CROPPING YEAR

[If several household members earn the same income source, fill according to the earning family member in separate rows]

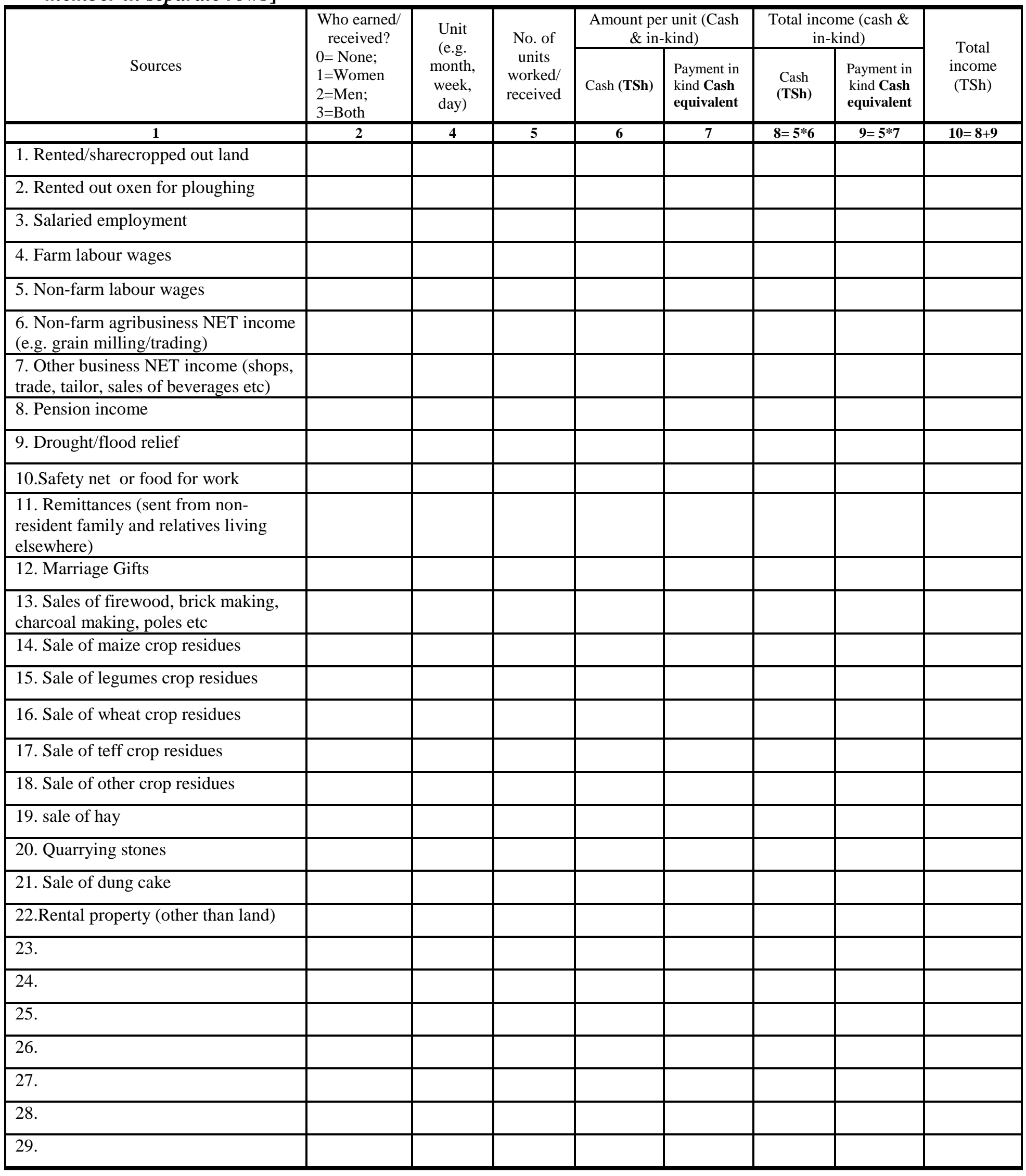


PART 9: ACCESS TO FINANCIAL CAPITAL, INFORMATION AND INSTITUTIONS Section A: Household credit need and sources during 2008/09 cropping year

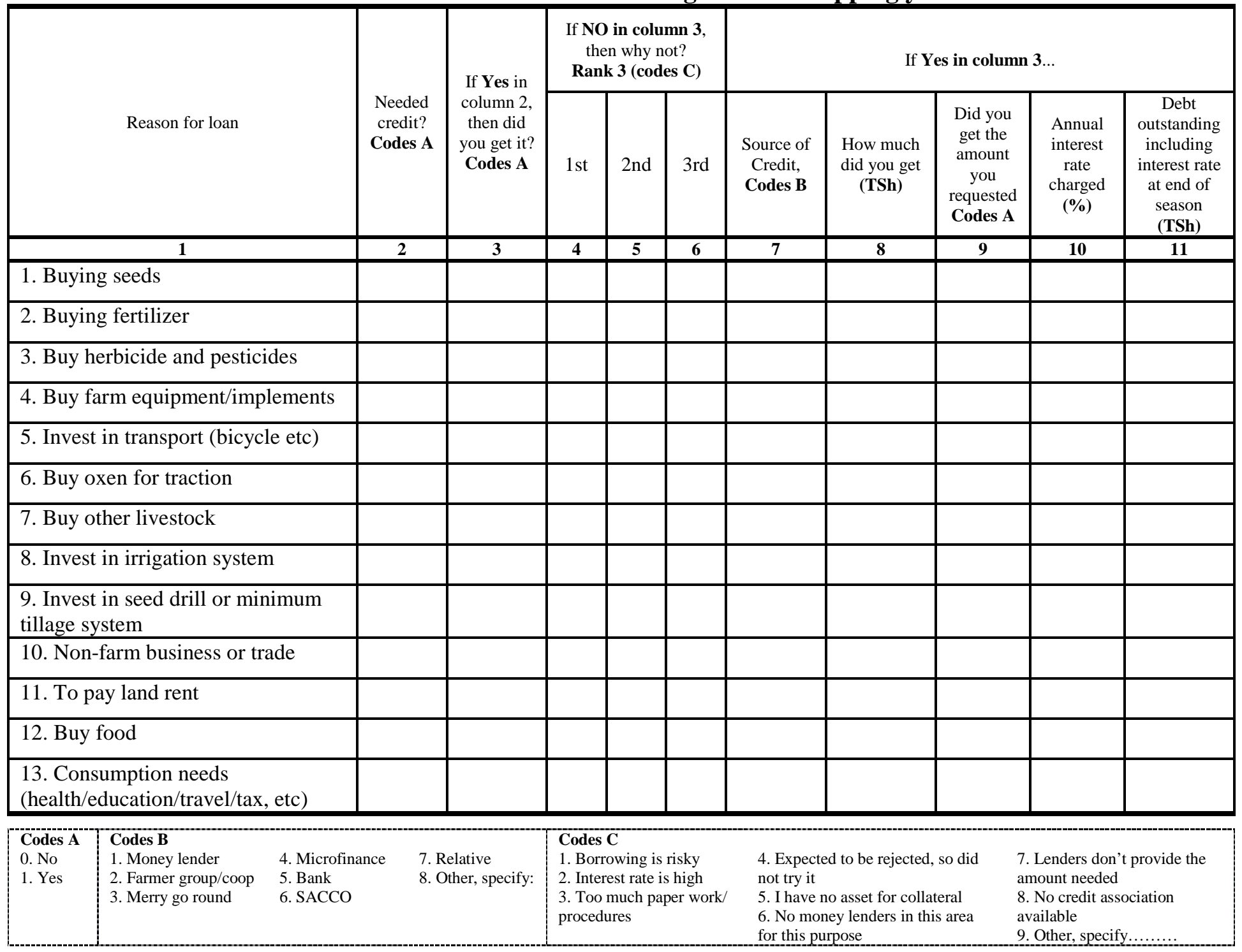

\section{Section B: Household savings}

\begin{tabular}{|c|c|c|c|}
\hline $\begin{array}{l}\text { Saving family member } \\
\text { (1=Husband; } 0=\text { Wife) }\end{array}$ & $\begin{array}{c}\text { Has bank account number } \\
(0=\text { No; } 1=\text { Yes })\end{array}$ & $\begin{array}{l}\text { Saving with } \\
\text { (codes A) }\end{array}$ & $\begin{array}{c}\text { Total amount saved } \\
\text { during 2008/09 (TSh) }\end{array}$ \\
\hline 1 & 2 & 3 & 5 \\
\hline & & & \\
\hline & & & \\
\hline & & & \\
\hline & & & \\
\hline & & & \\
\hline & & & \\
\hline & & & \\
\hline & & & \\
\hline & & & \\
\hline & & & \\
\hline & & & \\
\hline
\end{tabular}

\section{Codes A}

1. Saving at home (personal)

2. Commercial or other banks
7. Saving by lending to money lender

8. Other, specify. 
Section C: Access to extension services

\begin{tabular}{|c|c|c|c|c|c|c|c|c|c|}
\hline \multirow{2}{*}{\multicolumn{2}{|c|}{ Issue }} & \multirow{2}{*}{$\begin{array}{c}\text { Did you receive } \\
\text { training or } \\
\text { information on } \\
\text { [......] before } \\
\text { 2008/09? } \\
\text { (Codes } \mathbf{A})\end{array}$} & \multirow{2}{*}{$\begin{array}{c}\text { Received } \\
\text { training or } \\
\text { information on } \\
\text { [.....] during } \\
\text { 2008/09? } \\
\text { (Codes A) }\end{array}$} & \multicolumn{3}{|c|}{$\begin{array}{c}\text { Main information source for } \\
2008 / 09 \\
\text { (codes B) } \\
\end{array}$} & \multicolumn{3}{|c|}{$\begin{array}{c}\text { Number of contacts during 2008/09 } \\
\text { (days/year) }\end{array}$} \\
\hline & & & & Rank 1 & Rank 2 & Rank 3 & $\begin{array}{c}\text { Govt } \\
\text { extension }\end{array}$ & $\begin{array}{l}\text { Non- } \\
\text { profit } \\
\text { NGOs }\end{array}$ & $\begin{array}{l}\text { Private } \\
\text { Companies }\end{array}$ \\
\hline & 1 & 2 & 3 & 4 & 5 & 6 & 7 & 8 & 9 \\
\hline \multicolumn{10}{|c|}{ 1. New varieties of maize } \\
\hline \multicolumn{10}{|c|}{ 2. New varieties of legumes } \\
\hline \multicolumn{10}{|c|}{ 3. Field pest and disease control } \\
\hline \multicolumn{10}{|c|}{ 4. Soil and water management } \\
\hline \multicolumn{10}{|c|}{ 5. Crop rotation } \\
\hline \multicolumn{10}{|c|}{ 6. Minimum tillage } \\
\hline \multicolumn{10}{|c|}{ 7. Leaving crop residue in the field } \\
\hline \multicolumn{10}{|c|}{ 8. Adaptation to climate change } \\
\hline \multicolumn{10}{|c|}{ 9. Irrigation } \\
\hline \multicolumn{10}{|c|}{ 10. Crop storage pests } \\
\hline \multicolumn{10}{|c|}{ 11. Output markets and prices } \\
\hline \multicolumn{10}{|c|}{ 12. Input markets and prices } \\
\hline \multicolumn{10}{|c|}{ 13. Collective action/farmer organization } \\
\hline \multicolumn{10}{|c|}{ 14. Livestock production } \\
\hline \multicolumn{10}{|c|}{ 15. Family health } \\
\hline \multicolumn{10}{|c|}{ 16. Sanitation } \\
\hline \multicolumn{10}{|c|}{ 17. Family planning } \\
\hline \multicolumn{10}{|c|}{ 18. Tree planting } \\
\hline $\begin{array}{l}\text { Codes A } \\
0 . \text { No } \\
\text { 1. Yes }\end{array}$ & $\begin{array}{l}\text { Codes B } \\
\text { 1. Government extension service } \\
\text { 2. Farmer Coop or groups } \\
\text { 3. Neighbour farmers }\end{array}$ & $\begin{array}{l}\text { 4. Seed traders/Agrovets } \\
\text { 5. Relative farmers } \\
\text { 6. NGOs }\end{array}$ & $\begin{array}{l}\text { 7. Other priv } \\
\text { 8. Private Co } \\
\text { 9. Research }\end{array}$ & $\begin{array}{l}\text { e trader } \\
\text { hpany } \\
\text { nter }\end{array}$ & $\begin{array}{l}\text { 10. Sch } \\
\text { 11. Rad } \\
\text { 12. Ney }\end{array}$ & & $\begin{array}{l}\text { 12. Mobi } \\
\text { 13. Other, }\end{array}$ & $\begin{array}{l}\text { phone } \\
\text { specify... }\end{array}$ & \\
\hline
\end{tabular}

Section D. Market access

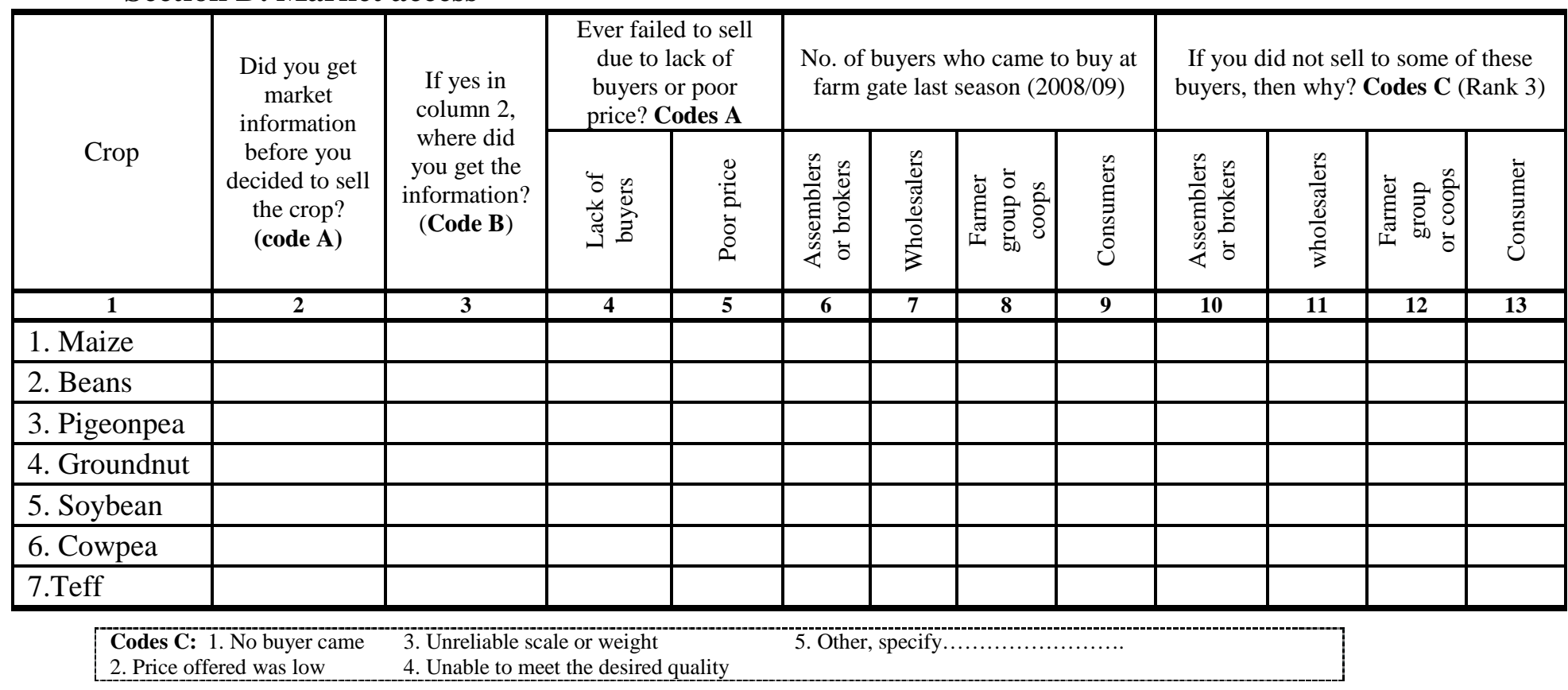


Section E: Constraints in access key inputs and crop production (SIMLESA crops only)

\begin{tabular}{|c|c|c|c|c|c|c|c|c|c|c|c|c|}
\hline \multirow[b]{2}{*}{ Input and production constraints } & \multicolumn{2}{|c|}{ Maize } & \multicolumn{2}{|c|}{ Beans } & \multicolumn{2}{|c|}{ Pigeonpea } & \multicolumn{2}{|c|}{ Groundnut } & \multicolumn{2}{|c|}{ Teff } & \multicolumn{2}{|c|}{ Other, specify...... } \\
\hline & $\begin{array}{l}\text { Constraint? } \\
\text { Codes A }\end{array}$ & $\begin{array}{l}\text { Rank its } \\
\text { importance } \\
\text { (only those } \\
\text { with Yes in } \\
\text { column 2) }\end{array}$ & $\begin{array}{c}\text { Constraint? } \\
\text { Codes A }\end{array}$ & $\begin{array}{l}\text { Rank its } \\
\text { importance } \\
\text { (only those } \\
\text { with Yes in } \\
\text { column 4) }\end{array}$ & $\begin{array}{c}\text { Constraint? } \\
\text { Codes A }\end{array}$ & $\begin{array}{c}\text { Rank its } \\
\text { importance } \\
\text { (only those } \\
\text { with Yes in } \\
\text { column 6) }\end{array}$ & $\begin{array}{c}\text { Constraint? } \\
\text { Codes A }\end{array}$ & $\begin{array}{c}\text { Rank its } \\
\text { importance } \\
\text { (only those } \\
\text { with Yes in } \\
\text { column 8) }\end{array}$ & $\begin{array}{c}\text { Constraint? } \\
\text { Codes A }\end{array}$ & $\begin{array}{c}\text { Rank its } \\
\text { importance } \\
\text { (only those } \\
\text { with Yes in } \\
\text { column 10) }\end{array}$ & $\begin{array}{c}\text { Constraint? } \\
\text { Codes A }\end{array}$ & $\begin{array}{c}\text { Rank its } \\
\text { importance } \\
\text { (only those } \\
\text { with Yes in } \\
\text { column 12) }\end{array}$ \\
\hline 1 & 2 & 3 & 4 & 5 & 6 & $\begin{array}{ll}7 \\
\end{array}$ & 8 & 9 & 10 & 11 & 12 & 13 \\
\hline \multicolumn{13}{|l|}{ Socioeconomic } \\
\hline \multicolumn{13}{|l|}{ 1. Timely availability of improved seed } \\
\hline \multicolumn{13}{|l|}{ 2. Prices of improved seed } \\
\hline \multicolumn{13}{|l|}{ 3. Quality of seed } \\
\hline \multicolumn{13}{|l|}{ 4. Availability of credit to buy seed } \\
\hline \multicolumn{13}{|l|}{ 5. Timely availability of fertilizer } \\
\hline \multicolumn{13}{|l|}{ 6. Price of fertilizer } \\
\hline \multicolumn{13}{|l|}{ 7. Availability of credit to buy fertilizer } \\
\hline \multicolumn{13}{|l|}{ 8. Access to markets and information } \\
\hline \multicolumn{13}{|l|}{ 9. Reasonable grain prices } \\
\hline \multicolumn{13}{|l|}{ Biophysical } \\
\hline \multicolumn{13}{|l|}{ 10. Drought } \\
\hline \multicolumn{13}{|l|}{ 11. Floods } \\
\hline \multicolumn{13}{|l|}{ 12. Pests } \\
\hline \multicolumn{13}{|l|}{ 13. Diseases } \\
\hline \multicolumn{13}{|l|}{ 14. Soil fertility } \\
\hline 15. & & & & & & & & & & & & \\
\hline
\end{tabular}

Codes A: 0 . No; 1 . Yes

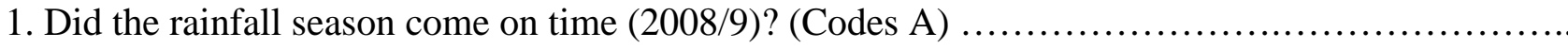

2. Was there enough rain at the beginning of the growing season? (Codes $A$ ).

3. Was there enough rain during the growing season? (Codes $\mathrm{A})$...

4. Did the rains stop on time? (Codes A).

5. Did it rain near the harvest time? (Codes A). 
PART 10: RISK, LIVELIHOOD SHOCKS AND COPING STRATEGIES

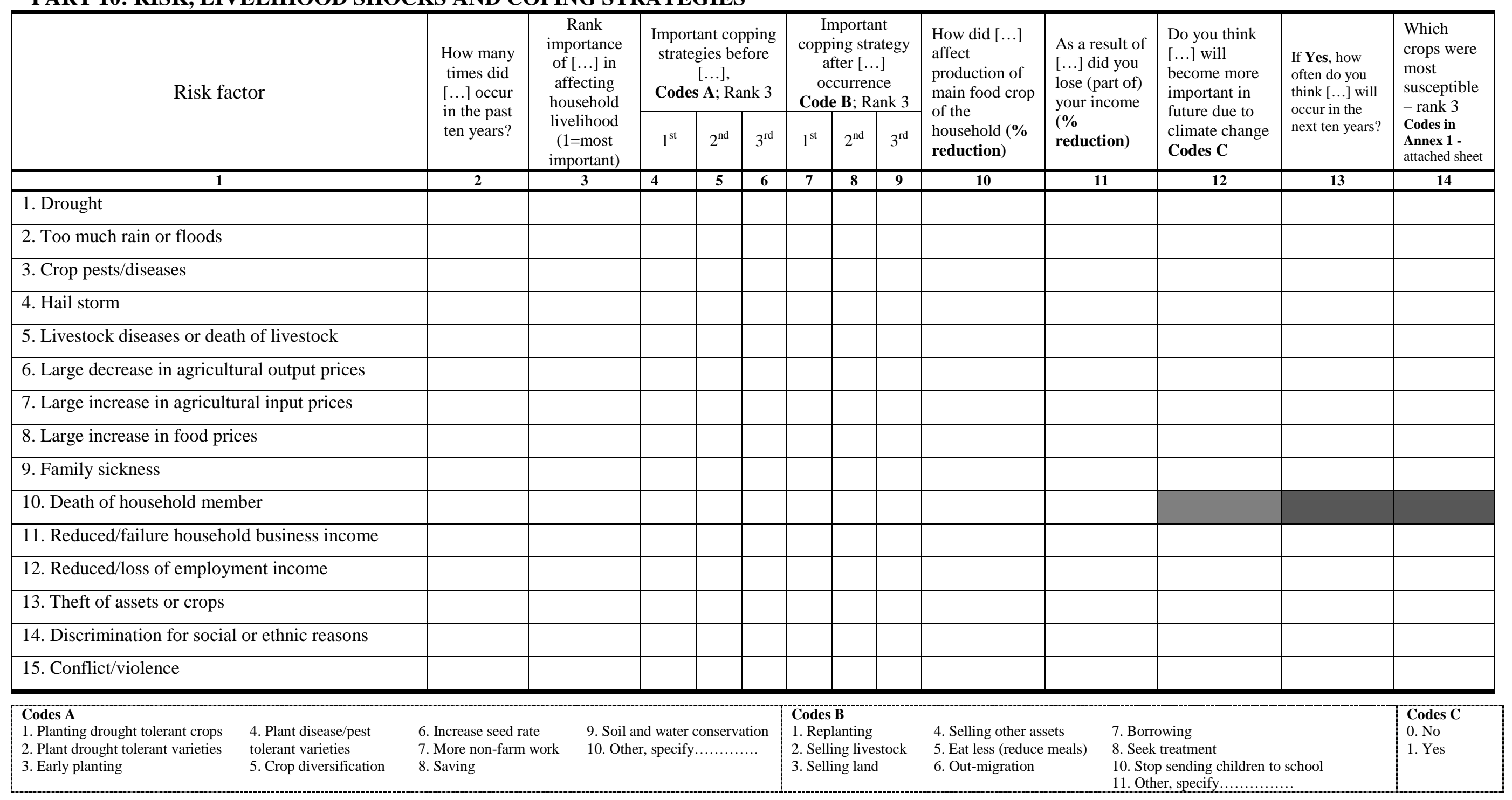


PART 11. HOUSEHOLD EXPENDITURE

(not during 2008/09 but looking back from today)

(Here, wife and/or the person involved in purchases should be the principal respondent/s).

Section A: Food consumption

\begin{tabular}{|c|c|c|c|c|c|c|c|c|c|}
\hline \multirow{2}{*}{ Ite } & \multirow{2}{*}{$\begin{array}{l}\text { Unit (e.g. } \\
\text { kg, liter, } \\
\text { packet, } \\
\text { bundle) }\end{array}$} & \multicolumn{3}{|c|}{$\begin{array}{c}\text { Total consumed in the last } 7 \\
\text { days for only members of the } \\
\text { family }\end{array}$} & \multicolumn{5}{|c|}{ Bought in the last 12 months } \\
\hline & & $\begin{array}{c}\text { Own } \\
\text { produced }\end{array}$ & Bought & $\begin{array}{l}\text { Cost of } \\
\text { bought } \\
\text { (TSh) }\end{array}$ & $\begin{array}{c}\text { Frequency of } \\
\text { buying (e.g., } 2 \\
\text { times per month) }\end{array}$ & $\begin{array}{c}\text { Average } \\
\text { quantity each } \\
\text { time (e.g. } 2 \mathrm{~kg} \text {; } \\
4 \text { bundles etc) }\end{array}$ & $\begin{array}{c}\text { Total } \\
\text { quantity } \\
\text { per year }\end{array}$ & $\begin{array}{c}\text { Average } \\
\text { price per } \\
\text { unit } \\
\text { (TSh) }\end{array}$ & $\begin{array}{l}\text { Total cost } \\
\text { of } \\
\text { purchased } \\
\text { (TSh) }\end{array}$ \\
\hline 1 & 2 & 3 & 4 & 5 & 6 & 7 & 8 & 9 & $10=8^{*} 9$ \\
\hline \multicolumn{10}{|c|}{ Staple foods } \\
\hline \multicolumn{10}{|c|}{ 1. Maize (dry) } \\
\hline \multicolumn{10}{|c|}{ 2. Maize (green) } \\
\hline \multicolumn{10}{|c|}{ 3. Teff } \\
\hline \multicolumn{10}{|l|}{ 4. Wheat } \\
\hline \multicolumn{10}{|l|}{ 5. Barley } \\
\hline \multicolumn{10}{|l|}{ 6. Rice } \\
\hline \multicolumn{10}{|l|}{ 7. Sorghum } \\
\hline \multicolumn{10}{|l|}{ 8. F/millet } \\
\hline \multicolumn{10}{|l|}{ 9. P/millet } \\
\hline \multicolumn{10}{|l|}{ 10. Cassava } \\
\hline \multicolumn{10}{|l|}{ 11. Potatoes } \\
\hline \multicolumn{10}{|l|}{ 12. Beans dry } \\
\hline \multicolumn{10}{|c|}{ 13. Beans fresh } \\
\hline \multicolumn{10}{|c|}{ 14. Cowpea fresh grain } \\
\hline \multicolumn{10}{|c|}{ 15. Cowpea dry grain } \\
\hline \multicolumn{10}{|c|}{ 16. Cowpea leaves } \\
\hline \multicolumn{10}{|c|}{ 17. Groundnut fresh } \\
\hline \multicolumn{10}{|c|}{ 18. Groundnut dry } \\
\hline 19. Soybean & & & & & & & & & \\
\hline 20. Pigeonpea & & & & & & & & & \\
\hline 21. Pigeonpea & & & & & & & & & \\
\hline 22. Greengran & & & & & & & & & \\
\hline 23. Bananas (f & & & & & & & & & \\
\hline 24. & & & & & & & & & \\
\hline 25. & & & & & & & & & \\
\hline Vegetables & & & & & & & & & \\
\hline 27. Tomatoes & & & & & & & & & \\
\hline 28. Onions & & & & & & & & & \\
\hline 29. Cabbage & & & & & & & & & \\
\hline 30. Spinach & & & & & & & & & \\
\hline 31. Kale & & & & & & & & & \\
\hline 32. Carrot & & & & & & & & & \\
\hline 33. Okra & & & & & & & & & \\
\hline 34. Pumpkin & & & & & & & & & \\
\hline 35. Egg plant & & & & & & & & & \\
\hline 36.Cucumber & & & & & & & & & \\
\hline 37.Pepper & & & & & & & & & \\
\hline 38. Garlic & & & & & & & & & \\
\hline 39. & & & & & & & & & \\
\hline
\end{tabular}


Section A: Food consumption (contd)

\begin{tabular}{|c|c|c|c|c|c|c|c|c|c|}
\hline \multirow[b]{2}{*}{ Item } & \multirow{2}{*}{$\begin{array}{l}\text { Unit (e.g. } \\
\text { kg, liter, } \\
\text { packet, } \\
\text { bundle) }\end{array}$} & \multicolumn{3}{|c|}{$\begin{array}{c}\text { Total consumed in the last } 7 \\
\text { days for only members of the } \\
\text { family }\end{array}$} & \multicolumn{5}{|c|}{ Bought in the last 12 months } \\
\hline & & $\begin{array}{l}\text { Own } \\
\text { produced }\end{array}$ & Bought & $\begin{array}{l}\text { Cost of } \\
\text { bought } \\
\text { (TSh) }\end{array}$ & $\begin{array}{c}\text { Frequency of } \\
\text { buying (e.g., } \\
\text { times per month) }\end{array}$ & $\begin{array}{l}\text { Average quantity } \\
\text { each time (e.g. } 2 \\
\mathrm{~kg} ; 4 \text { bundles } \\
\text { etc) }\end{array}$ & $\begin{array}{l}\text { Total } \\
\text { quantity } \\
\text { per year }\end{array}$ & $\begin{array}{c}\text { Average } \\
\text { price per } \\
\text { unit } \\
\text { (TSh) }\end{array}$ & $\begin{array}{l}\text { Total cost of } \\
\text { purchased } \\
\text { (TSh) }\end{array}$ \\
\hline 1 & 2 & 3 & 4 & 5 & 6 & 7 & 8 & 9 & 10 \\
\hline \multicolumn{10}{|l|}{ Fruits } \\
\hline \multicolumn{10}{|l|}{ 41. Oranges } \\
\hline \multicolumn{10}{|l|}{ 42. Mangoes } \\
\hline \multicolumn{10}{|l|}{ 43. Pawpaws } \\
\hline \multicolumn{10}{|l|}{ 44. Pineapple } \\
\hline \multicolumn{10}{|l|}{ 45. Bananas (ripe) } \\
\hline \multicolumn{10}{|l|}{ 46. Apple } \\
\hline \multicolumn{10}{|l|}{ 47. Guava } \\
\hline \multicolumn{10}{|l|}{ 48. Coconut } \\
\hline \multicolumn{10}{|l|}{ 49. Sugar cane } \\
\hline \multicolumn{10}{|l|}{50.} \\
\hline \multicolumn{10}{|l|}{51.} \\
\hline \multicolumn{10}{|c|}{ Meat \& other animal products } \\
\hline \multicolumn{10}{|l|}{ 52. Cow meat } \\
\hline \multicolumn{10}{|l|}{ 53. Goat meat } \\
\hline \multicolumn{10}{|l|}{ 54. Sheep meat } \\
\hline \multicolumn{10}{|l|}{ 55. Pig meat } \\
\hline \multicolumn{10}{|l|}{ 56. Chicken } \\
\hline 57. Turkey & & & & & & & & & \\
\hline 58. Ducks & & & & & & & & & \\
\hline 59. Bush meat & & & & & & & & & \\
\hline 60. Fish & & & & & & & & & \\
\hline 61. Eggs & & & & & & & & & \\
\hline 62. Milk & & & & & & & & & \\
\hline 63. Cheese/Ghee & & & & & & & & & \\
\hline 64. Butter & & & & & & & & & \\
\hline 65. Yoghurt & & & & & & & & & \\
\hline 66. Honey & & & & & & & & & \\
\hline 67. & & & & & & & & & \\
\hline 68. & & & & & & & & & \\
\hline Beverages and $\mathbf{d}$ & & & & & & & & & \\
\hline 69. Tea (leaves) & & & & & & & & & \\
\hline 70. Tea (liquid) & & & & & & & & & \\
\hline $\begin{array}{l}\begin{array}{l}\text { 71. Coffee } \\
\text { (powder) }\end{array} \\
\end{array}$ & & & & & & & & & \\
\hline 72. Coffee (liquid) & & & & & & & & & \\
\hline 73. Soft drinks & & & & & & & & & \\
\hline 74. Juices & & & & & & & & & \\
\hline 75. Local beer & & & & & & & & & \\
\hline 76. Bottled beer & & & & & & & & & \\
\hline 77. Wine & & & & & & & & & \\
\hline 78. Drinking water & & & & & & & & & \\
\hline
\end{tabular}


Section A: Food consumption (contd)

\begin{tabular}{|c|c|c|c|c|c|c|c|c|c|}
\hline \multirow{2}{*}{ Item } & \multirow{2}{*}{$\begin{array}{l}\text { Unit (e.g. } \\
\text { kg, liter, } \\
\text { packet, } \\
\text { bundle) }\end{array}$} & \multicolumn{3}{|c|}{$\begin{array}{l}\text { Total consumed in the last } 7 \\
\text { days for only members of the } \\
\text { family } \\
\end{array}$} & \multicolumn{5}{|c|}{ Bought in the last 12 months } \\
\hline & & $\begin{array}{l}\text { Own } \\
\text { produced }\end{array}$ & Bought & $\begin{array}{l}\text { Cost of } \\
\text { bought } \\
\text { (TSh) }\end{array}$ & $\begin{array}{l}\text { Frequency of } \\
\text { buying (e.g., } 2 \\
\text { times per month) }\end{array}$ & $\begin{array}{l}\text { Average quantity } \\
\text { each time (e.g. } 2.2 \\
\text { kg; } 4 \text { bundles } \\
\text { etc) }\end{array}$ & $\begin{array}{l}\text { Total } \\
\text { quantity } \\
\text { per year }\end{array}$ & $\begin{array}{l}\text { Average } \\
\text { price per } \\
\text { unit } \\
\text { (TSh) }\end{array}$ & $\begin{array}{c}\text { Total cost of } \\
\text { purchased } \\
\text { (TSh) }\end{array}$ \\
\hline 1 & 2 & 3 & 4 & 5 & 6 & 7 & 8 & 9 & 10 \\
\hline \multicolumn{10}{|c|}{ Beverages and drinks (contd) } \\
\hline \multicolumn{10}{|c|}{\begin{tabular}{l|l|l}
80. Water for & & \\
livestock &
\end{tabular}} \\
\hline \multicolumn{10}{|c|}{$\begin{array}{l}\text { 81. Water for other } \\
\text { uses }\end{array}$} \\
\hline \multicolumn{10}{|l|}{82.} \\
\hline \multicolumn{10}{|l|}{83.} \\
\hline \multicolumn{10}{|c|}{\begin{tabular}{l|l|l|l}
84. & & & \\
\end{tabular}} \\
\hline \multicolumn{10}{|c|}{ Fats, oils, sweeteners, snacks and others } \\
\hline \multicolumn{10}{|c|}{\begin{tabular}{l|l|l|l|} 
85. Cooking fat & & & \\
\end{tabular}} \\
\hline \multirow{2}{*}{\multicolumn{10}{|c|}{$\frac{86 . \text { Margarine }}{87 \text { Groundnut oil }}$}} \\
\hline \multirow{2}{*}{\multicolumn{10}{|c|}{ 87. Groundnut oll }} \\
\hline & & & & & & & & & \\
\hline \multicolumn{10}{|c|}{ 89. Bread } \\
\hline \multicolumn{10}{|l|}{ 90. Biscuits } \\
\hline \multicolumn{10}{|l|}{ 91. Popcorrn } \\
\hline \multicolumn{10}{|c|}{ 92. Cashew nuts } \\
\hline \multicolumn{10}{|l|}{ 93. Sugar } \\
\hline \multicolumn{10}{|l|}{ 94. Salt } \\
\hline \multicolumn{10}{|l|}{ 95. Chocolate } \\
\hline \multicolumn{10}{|l|}{96. Curry } \\
\hline \multicolumn{10}{|l|}{ 97. Ginger } \\
\hline \multicolumn{10}{|l|}{98.} \\
\hline \multicolumn{10}{|c|}{\begin{tabular}{l|l|l|l}
99. & & & \\
\end{tabular}} \\
\hline \multicolumn{10}{|c|}{ Meals eaten away from home (specify) } \\
\hline \multicolumn{10}{|c|}{\begin{tabular}{l|l|l|l|}
100. & & & \\
\end{tabular}} \\
\hline \multicolumn{10}{|l|}{101.} \\
\hline \multicolumn{10}{|l|}{102.} \\
\hline 103. & & & & & & & & & \\
\hline 104. & & & & & & & & & \\
\hline
\end{tabular}


Section B: Expenditure on non-food items in the last 12 months

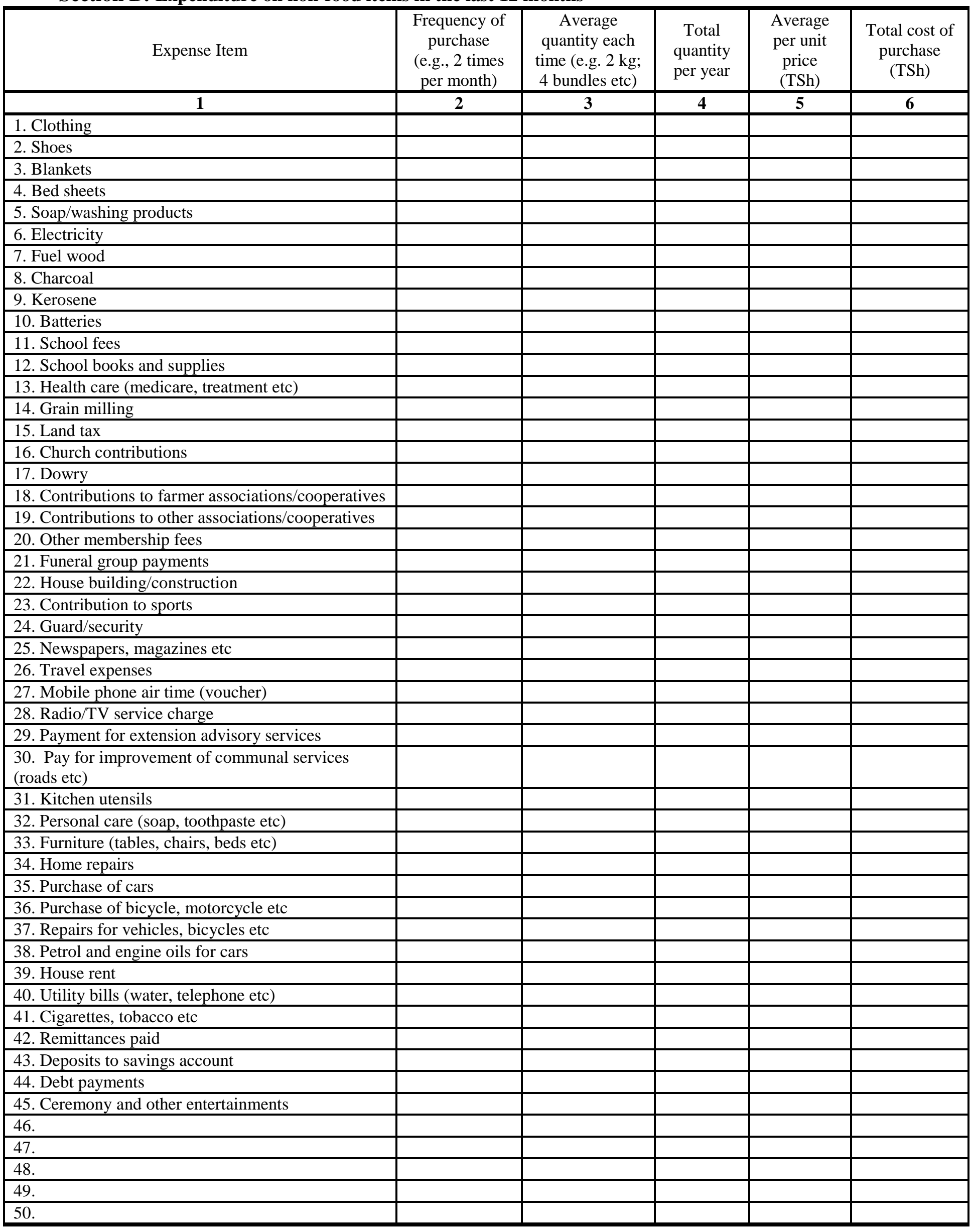


ANNEX 1: CROP CODES

\begin{tabular}{|c|c|c|c|c|c|c|}
\hline 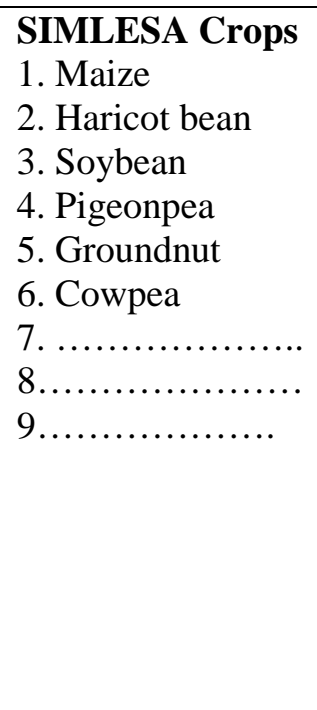 & 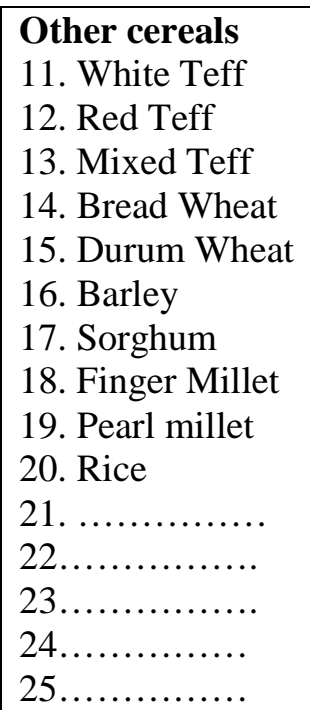 & 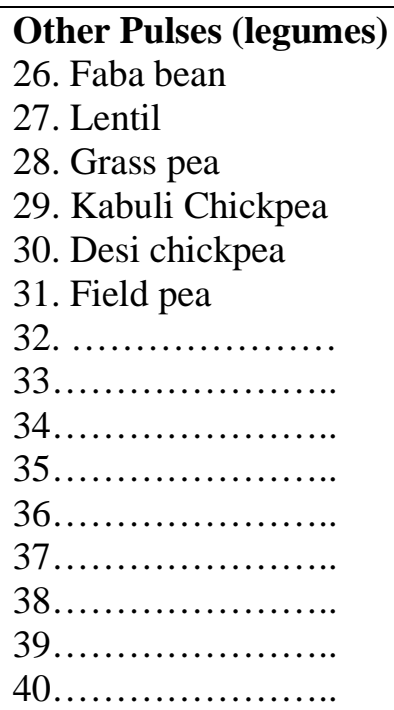 & $\begin{array}{l}\text { Oil Crops } \\
\text { 41. Nigerseed } \\
\text { 42. Sunflower } \\
\text { 43.Sesame } \\
\text { 44.Linseed } \\
\text { 45.Rapeseed } \\
46 . \text { Lupin }\end{array}$ & 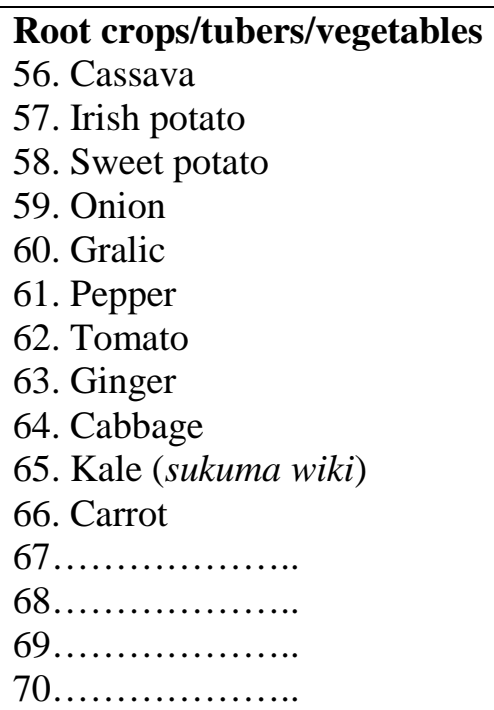 & 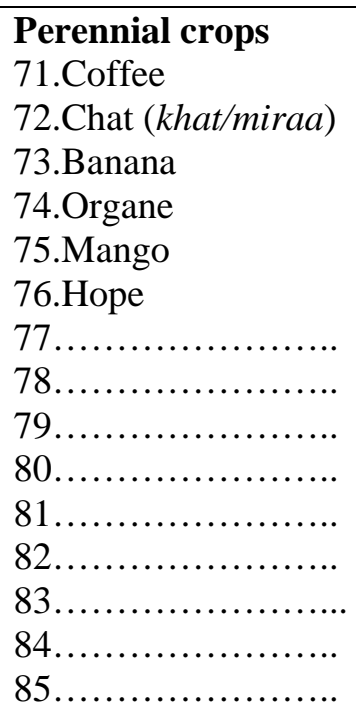 & $\begin{array}{l}\text { Fodder legumes } \\
\text { 86. Lablab } \\
\text { 87. Clover } \\
\text { 88. Vetch } \\
\text { 89. Alfalfa } \\
\text { 90. Sesbania } \\
91 \ldots \ldots \ldots \ldots \\
92 \ldots \ldots \ldots\end{array}$ \\
\hline
\end{tabular}

\section{ANNEX 2: CROP VARIETY CODES (vary by country)}

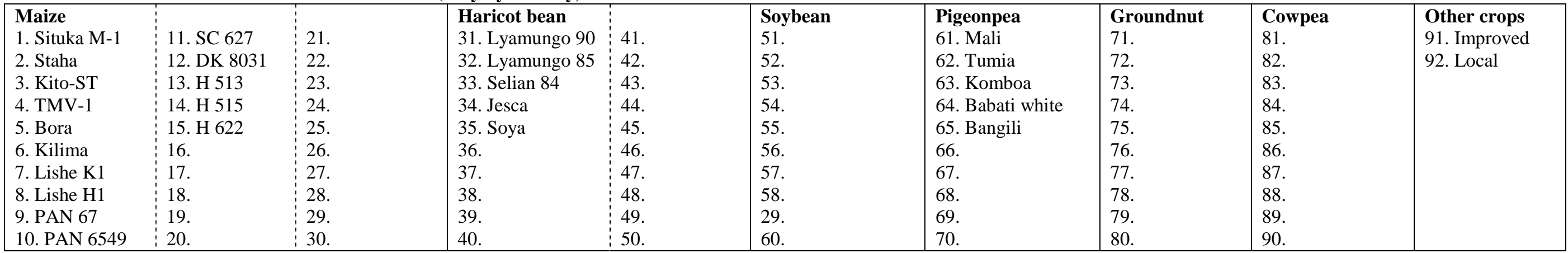

